MARIA JACKELINE CHAVARRIA MORA

SISTEMA DE CERTIFICAÇÃO DA QUALIDADE DE CONDOMÍNIOS LOGÍSTICOS NO BRASIL 
Este exemplar foi revisado e corrigido em relação à versão original, sob responsabilidade única do autor e com a anuência de seu orientador.

São Paulo de de

Assinatura do autor:

Assinatura do orientador:

Catalogação-na-publicação

Mora, Maria Jackeline Chavarria Mora

SISTEMA DE CERTIFICAC̄̃O DA QUALIDADE DE CONDOMÍNIOS

LOGÍSTICOS NO BRASIL / M. J. C. M. Mora - versão corr. -- São Paulo, 2016.

$108 \mathrm{p}$.

Dissertação (Mestrado) - Escola Politécnica da Universidade de São Paulo. Departamento de Engenharia de Construção Civil.

1.Certificação de Qualidade 2.Galpões 3.Condomínio Logísticos I.Universidade de São Paulo. Escola Politécnica. Departamento de Engenharia de Construção Civil Il.t. 
MARIA JACKELINE CHAVARRIA MORA

\title{
SISTEMA DE CERTIFICAÇÃO DA QUALIDADE DE CONDOMÍNIOS LOGÍSTICOS NO BRASIL
}

\author{
Dissertação apresentada à Escola \\ Politécnica da Universidade de São \\ Paulo para a obtenção do Título de \\ Mestre em Ciências. \\ Área de Concentração: \\ Engenharia de Construção Civil \\ Orientador: \\ Prof. Doutor \\ João da Rocha Lima Jr.
}

São Paulo

2016 
A Deus, minha família de sangre e a minha família de coração, verdadeira ração para nunca desistir. 


\section{AGRADECIMENTOS}

Agradeço a Deus por me dar sabedoria, paz e vontade para levar este projeto até o fim.

A todos meus professores, especialmente ao Professor Claudio Tavares de Alencar, pela paciência e suas valiosas orientações e disponibilidade.

A Professora Eliane Monetti, pelas contribuições ao longo da dissertação e ao Professor João da Rocha Lima Jr, pelos valiosos ensinamentos de Real Estate.

Ao meu querido Juan David pela ajuda incondicional e amorosa compreensão e a minha amiga Silene pelo grande apoio e amor. 


\section{RESUMO}

Atualmente no mercado brasileiro de condomínios de galpões logísticos são ofertados empreendimentos em variados estratos de qualidade. Isto decorre do grande espectro de necessidades e demandas de uma ampla variedade de usuários interessados em ocupar Condomínios Logísticos (CL). De modo geral, os usuários desta tipologia de empreendimento procuram, além da eficiência de armazenagem, outros serviços e atributos tais como: localização privilegiada, moderna infraestrutura de sistemas prediais, forte segurança patrimonial, incentivos fiscais na região, flexibilidade no projeto para ajustar as instalações existentes a requisitos operacionais específicos, entre outros.

A partir do conjunto de atributos de qualidade oferecidos aos usuários é possível enquadrar empreendimentos deste segmento em classes específicas que permitam o mercado fazer uma leitura sem viés do padrão de qualidade dos empreendimentos em oferta, a exemplo do que já é utilizado em outros segmentos de empreendimentos de Base Imobiliária no Brasil.

Contudo, um sistema de classificação de CL rigoroso e isento de viés é inexistente hoje no Brasil. O mercado dispõe exclusivamente de critérios formulados pelas empresas responsáveis pela comercialização dos espaços nos empreendimentos, o que compromete a isenção da avaliação da qualidade para o usuário. Esta notória ausência de um sistema de classificação reclama a construção de critérios mais bem fundamentados e com análise do estado dos atributos, sob o ponto de vista do usuário de CLs.

Portanto o objetivo desta pesquisa é desenvolver um sistema de certificação da qualidade de

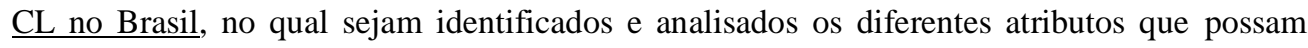
enquadrar um empreendimento dentro de uma classe específica, para dar suporte a uma leitura de qualidade dos empreendimentos pelo mercado.

Para atingir o objetivo mencionado, foi necessário identificar os principais aspectos comuns às classificações existentes no mercado de CL através de levantamento bibliográfico e de práticas de mercado, para, em seguida, eleger uma metodologia de análise que permita avaliar os atributos que fundamentam na visão dos usuários o que configura a qualidade dos CLs. O método empregado foi o Delphi, que envolve a aplicação sucessivas de questionários a especialistas no tema, com o intuito de reconhecer a opinião prevalente acerca da qualidade de CL segundo o ponto de vista de seus usuários típicos.

Deste modo, os resultados alcançados são, i) construção de uma Matriz de atributos que identifica a importância relativa dos sistemas e atributos requeridos pelos usuários de CLs , ii) construção de um sistema de classificação da qualidade de CLs para ser oferecido ao mercado. 


\begin{abstract}
Currently in the Brazilian Warehouses Business Park (WBP) are offered projects in varying quality strata. This follows from the broad spectrum of needs and demands of a wide variety of users interested in occupying charges (WBP). In general, users of this project typology looking beyond the storage efficiency, other services and attributes such as: prime location, modern infrastructure building systems, strong balance security, tax incentives in the region, design flexibility to adjust the facilities existing specific operational requirements, among others.

From the set of quality attributes offered to users can frame projects this segment in specific classes that allow the market to do a reading without standard bias quality of the projects on offer, similar to what is already used in other segments of enterprises Base of Real Estate in Brazil.

However, a strict classification system of WBP whit free bias is nonexistent today in Brazil. The market has only criteria formulated by the companies responsible for marketing the spaces in the projects, which compromises the quality assessment of the exemption for the user. This notorious absence of a classification system calls for the construction of wellfounded criteria and analysis of the state of the attributes from the point of view of WBP user. Therefore the aim of this research is to develop a quality certification system to Warehouses Business Park in Brazil, which are identified and analyzed the different attributes that can frame a project within a specific class, to support a quality reading of developments in the market .

To achieve the goal mentioned, it was necessary to identify key commonalities of existing ratings in the WBP market through literature and market practices, to then elect a methodology for assessing the attributes that support the vision of users which sets the quality of WBP. The method used was Delphi, which involves the successive application of questionnaires to experts on the subject, in order to recognize the prevailing opinion about the quality of WBP from the point of view of their typical users.

Thus, the results obtained are i) construction of an array of attributes that identify the relative importance of the attributes required for systems and users shed, ii) construct a quality classification system of WBP to be offered to the market.
\end{abstract}


SUMÁRIO

LISTA DE FIGURAS

LISTA DE TABELAS

1. INTRODUÇÃO .......................................................................................... 1

1.1. Contextualização ........................................................................... 1

1.2. Objetivos Gerais e Específicos. ................................................................... 6

1.3. Metodologia ..................................................................................................... 7

1.4. Estrutura do Sistema de Certificação de Qualidade de Condomínios

Logísticos no Brasil. ................................................................................................. 12

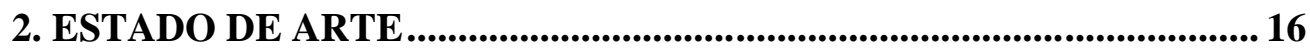

2.1. O mercado de condomínios logísticos............................................. 16

2.1.1 Conceituação do mercado .................................................................. 16

2.1.2 Gênese do setor .............................................................................................. 20

2.1.3 Comportamento setorial................................................................. 23

2.1.4 Classificações utilizadas no mercado de Condomínios Logísticos

3. IMPORTÂNCIA DO SISTEMA DE CLASSIFICAÇÃO DA QUALIDADE DE CONDOMÍNIOS LOGÍSTICOS .......................................33

3.1. Qualidade da pesquisa................................................................ 36

3.2. A certificação como parte desta pesquisa.............................................. 37

4. MÉTODO DE DESENVOLVIMENTO DO SISTEMA DE

CLASSIFICAÇÃ O................................................................................................ 39

4.1. Arbitragem da matriz inicial de atributos .......................................... 40

4.1.1 Identificação da opinião prevalente no mercado .......................... 41

4.1.2 Adoção da técnica Delphi ............................................................ 47

4.1.3 Seleção dos participantes................................................................ 48

4.1.4 Entrevistas com os participantes selecionados ................................. 49

4.1.5 Modelagem matriz inicial.......................................................................... 49 
4.2. Arbitragem das escalas de classificação ................................................... 51

4.3. Validação e calibragem do sistema de classificação............................ 52

5. SELEÇÃO DA TÉCNICA PARA O DESENVOLVIMENTO DO SISTEMA DE CERTIFICAÇÃO (TÉCNICA DELPHI). ............................ 55

6. DESCRIÇÃO GERAL DO SISTEMA DE CERTIFICAÇÃ̃................59

6.1. Sistema de classificação...............................................................60

6.1.1 Matriz de atributos........................................................................... 61

6.1.2 Escala de classificação ...................................................................68

6.1.3 Comitê de classificação .................................................................69

6.1.4 Processo de classificação................................................................. 69

6.2. Certificado da qualidade do galpão avaliado......................................... 70

6.3. Rotina para verificação da validade do certificado emitido............... 71

6.4. Mecanismos para atualização do sistema de classificação ................. 72

7. RESULTADO: ENTREGA DO MODELO DE CERTIFICAÇÃO DA

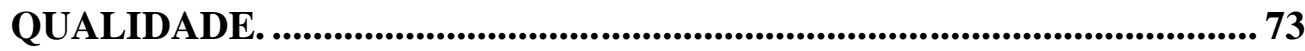

7.1. Calibragem e Aplicação da Matriz de Atributos ................................... 73 APÊNDICE A - APLICAÇÃO DA TÉCNICA DELPHI, VERONEZI

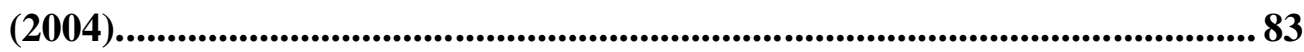

APÊNDICE B_- MATRIZ INIIAL DE ATRIBUTOS E ............................. 88 CERTIFICADO DE QUALIDADE DE CONDOMÍNIOS LOGÍSTICOS

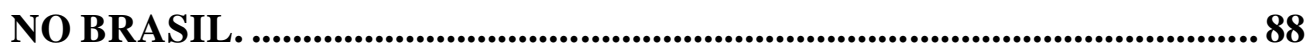

APÊNDICA C -_ARBITRAGEM DA TÉCNICA DELPHI, VERONEZI (2004) .96

APÊNDICA D -_ARBITRAGEM DA ESCALA DE CLASSIFICAÇÃO,

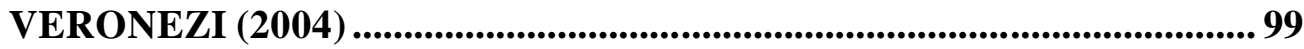

APÊNDICA E -_COMITÊ DE CLASSIFICAÇÃO, VERONEZI (2004) 103 APÊNDICA F - ARTIGOS, VERONEZI (2004) ..................................... 105 


\section{LISTA DE FIGURAS}

FIGURA 1 : EVOLUÇÃO DO ESTOQUE DE CONDOMÍNIO LOGÍSTICO NO BRASIL, FONTE IVISTA, (2016)................21 FIGURA 2: ESTOQUE ATUAL DE CONDOMÍNIO LOGÍSTICO NA CIDADE DE SÃO PAULO, FONTE IVISTA (2016).....22 FIGURA 3 - ÁREA DE CONDOMÍNIOS LOGÍSTICOS NO BRASIL, CONSTRUÍDO PELA AUTORA, ADAPTADO DO ILOS (2012) E COLLIERS 2014.

FIGURA 4 - INVENTARIO NACIONAL DE CL, CONSTRUÍDO PELO AUTOR, ADAPTADO DE COLLIERS INTERNATIONAL (2014)

FIGURA 5 - PORTE DOS CLIENTES DOS PRESTADORES DE SERVIÇO LOGÍSTICO NO BRASIL, FONTE ILOS 2013....26 FIGURA 6 - ILUSTRAÇÃO DO CL ARCOLOG, LOCALIZADO EM SEROPÉDIA, RJ, RODOVIA DUTRA, KM 204, INCORPORADO PELA EMPRESA VBI

FIGURA 7 - ILUSTRAÇÃO DO CL GLP CAMPINAS, LOCALIZADO EM CAMPINAS, SP, RODOVIA ANHANGUERA, KM 104, INCORPORADO PELA EMPRESA GLP

FIGURA 8 - ILUSTRAÇÃO DO CL GR CAMPINAS, LOCALIZADO EM CAMPINAS, SP, INCORPORADO PELA EMPRESA GR PROPERTIES

FIGURA 9 - ILUSTRAÇÃO DO CL GLP GRAVATAÍ, LOCALIZADO EM PORTO ALEGRE, RS NA ROD. RS-118, KM 11, INCORPORADO PELA EMPRESA GLP

FIGURA 10 - ILUSTRAÇÃO DO CL GR LOUVEIRA, LOCALIZADO EM LOUVEIRA, SP, ROD. ANHANGUERA KM 72 INCORPORADO PELA EMPRESA GR PROPERTIES

FIGURA 11 - FOTOGRAFIA DO CL CAJAMAR INDUSTRIAL PARK, LOCALIZADO EM LOUVEIRA, SP, ROD. ANHANGUERA KM 72 INCORPORADO PELA EMPRESA PROLOGIS, CCP

FIGURA 12 - FOTOGRAFIA DO CL CAJAMAR INDUSTRIAL PARK, LOCALIZADO EM LOUVEIRA, SP, ROD.

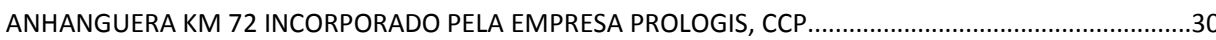
FIGURA 13 - ILUSTRAÇÃO DO CL EMBU II, LOCALIZADO EM EMBU, SP, INCORPORADO PELA EMPRESA HINES. 30 FIGURA 14 - ATRIBUTOS DETERMINANTES PARA A ESCOLHA DE CL (\% DE RESPONDENCIA) ELABORADO PELO AUTOR, ILOS 2013.

FIGURA 15 - FATORES DETERMINANTES PARA A ESCOLHA CL (\% DE RESPONDENCIA), ELABORADO PELO AUTOR CONFORME ILOS 2013.

FIGURA 16 - SISTEMA DE CERTIFICAÇÃO DA QUALIDADE DE CONDOMÍNIOS LOGÍSTICOS NO BRASIL.................60 FIGURA 17 - GRUPOS / SISTEMAS COMPONENTES DA MATRIZ DE ATRIBUTOS E NÚMERO DE ATRIBUTOS CONTIDOS EM CADA GRUPO

FIGURA 18 - FORMATO E COMPONENTES DA MATRIZ DE ATRIBUTOS. ..................................................................62

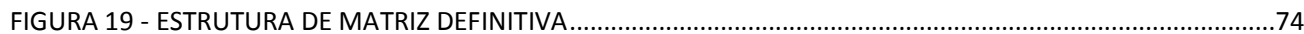

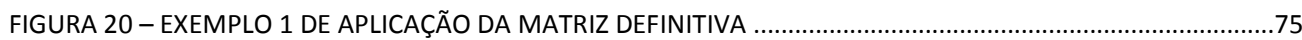

FIGURA 21 - EXEMPLO 2 DE APLICAÇÃO DA MATRIZ DEFINITIVA …………………………………………….....76 


\section{LISTA DE TABELAS}

TABELA 1 - CRITÉRIOS DE CLASSIFICAÇÃO DE CONDOMÍNIOS LOGÍSTICOS DE ACORDO COM COLLIERS INTERNACIONAL

TABELA 2 - EXEMPLOS DE SERVIÇOS ENCONTRADOS NOS PRINCIPAIS CONDOMÍNIOS LOGÍSTICOS CLASSE A OU A+, SEGUNDO INSTITUTO ILOS.

TABELA 3 - CRITÉRIOS DE AVALIAÇÃO DE CONDOMÍNIOS LOGÍSTICOS DE ACORDO COM COLLIERS INTERNACIONAL

TABELA 4 - TIPOLOGIAS DE CONDOMÍNIOS LOGÍSTICOS

TABELA 5 - CRITÉRIOS DE AVALIAÇÃO DE CONDOMÍNIOS LOGÍSTICOS 


\section{INTRODUÇÃO}

\subsection{Contextualização}

O desenvolvimento do mercado brasileiro de condomínios logísticos tem se ajustado às novas exigências e necessidades do mercado de logística, por causa da demanda por competitividade e eficiência presentes na operação das empresas e segmentos de negócios que se valem de grandes infraestruturas logísticas, inclusive de grandes centros de armazenagem. Percebe-se a preocupação no segmento do real estate que empreende condomínios de galpões logísticos a busca em oferecer soluções de projeto que encerrem os atributos adequados em termos de qualidade, de acordo com as necessidades dos potenciais usuários.

Passoni e Monetti (2006) afirmam que a partir de 1980 começa a se reconhecer no mercado brasileiro uma nova demanda por empreendimentos de condomínios logísticos, caracterizados pela necessidade de prover infraestrutura de armazenagem eficiente, flexível e segura para empresa industriais e do varejo, com atendimento à "modernização elou adequação de seus espaços aos novos padrões de produção e condução de negócios". Ainda, segundo Passoni e Monetti (2006), como resultado desta situação de adaptação às mudanças, foi criado um mercado com investidores imobiliários focados nos condomínios logísticos, com objetivos mais profissionais, preocupados com a eficiente inserção de mercado de seus empreendimentos.

Em outras palavras, este mercado de investidores imobiliários focados em condomínios logísticos foi adotando políticas de qualidade baseadas nas necessidades e demandas dos potenciais usuários de seus empreendimentos.

Assim, ao se conformar empreendimentos com uma serie de características oferecidas como diferentes atributos de qualidade para os usuários, surge uma variedade de tipologias de condomínios logísticos que podem ser encaixados em escalas distintas. Isto viabiliza o estabelecimento de uma hierarquização da qualidade dos atributos normalmente presentes em projetos de CLs, de acordo com o grau de importância relativa que usuários típicos do empreendimento lhe conferem. Deste modo, abre-se uma janela de oportunidade para se estabelecer um sistema de classificação da qualidade que possibilite uma comparação, com base em parâmetros criteriosamente construídos e permita ao mercado prescindir de avaliações sem vieses.

A criação de um sistema de certificação da qualidade de condomínios logísticos é o objetivo fundamental da presente pesquisa, na qual se exploram as tendências que fomentam a procura 
de Condomínios Logísticos $(\mathrm{CL})^{1}$ com múltiplos serviços e infraestrutura que vão além de uma área para armazenagem. O conjunto de atributos e serviços que garantem o desempenho de CL serão descritos no capítulo 2 (ESTADO DA ARTE).

De acordo com Viana (2013), “os condomínios logísticos surgem como alternativa, tanto para os Prestadores de Serviços Logísticos, como para as empresas em geral que necessitam utilizar instalações de armazenagem, para a diminuição dos riscos associados aos investimentos em ativos físicos".

Segundo o Instituto de Logística e Supply Chain ${ }^{2}$ (ILOS, 2013), o perfil de usuário de CL no Brasil varia de acordo com a região do país e com o Produto Interno Bruto (PIB) regional e com o tamanho do mercado consumidor, mas, os principais locatários de este tipo de empreendimento são os prestadores de serviços logísticos ${ }^{3}$ (PSL).

Ainda segundo o ILOS(2013), os PSL possuem um leque de clientes que na sua maioria são empresas dos setores de comércio varejista, eletroeletrônico, computação, higiene, limpeza e cosméticos.

Conforme a revista Tecnologística (2014 apud ILOS 2013), as empresas estão procurando os CL com o objetivo de trazer maiores vantagens operacionais e segurança, nos quais seja possível compartilhar os serviços entre os usuários. As empresas buscam CL com infraestruturas físicas modernas, as quais se adaptem às novas necessidades de aproveitamento das áreas verticais e possibilitem o uso de equipamentos de movimentação.

A infraestrutura de um condomínio logístico no Brasil, em termos gerais, conta com vários galpões dentro de um terreno com perímetro fechado e sob a administração de uma empresa. Isto significa que dentro de um mesmo condomínio podem conviver vários usuários PSL que se interessam em reconhecer o padrão de qualidade ou a classe do condomínio antes de assinar o contrato de locação do galpão. Neste sentido, é importante entender qual o grau de importância relativa que os atributos dos CL tem na opinião dos seus usuários. Estes usuários

\footnotetext{
${ }^{1}$ Condomínio Logístico é um termo que vai ser usado com muita frequência neste texto, portanto será substituído pelas siglas CL, na maioria das situações.

${ }^{2}$ ILOS, Instituto de Logística e Supply Chain, instituto voltado ao desenvolvimento da logística e supply chain.

${ }^{3}$ Prestadores de serviços logísticos é um termo muito usado neste texto y pode ser substituído pelas siglas PSL.
} 
procuram um local onde, além da armazenagem, existam outros serviços, tais como, boa localização, infraestrutura física, maior segurança patrimonial, incentivos fiscais e facilidade de adaptar as instalações existentes à operação, tal como mostrado na seção 4.1.1 Identificação de Atributos Prevalentes no Mercado.

No momento atual, os "atuantes do mercado" 4 (investidores, construtoras, empreendedores, desenvolvedores e projetistas) apresentam seus empreendimentos munidos dos seus atributos como características de projetos encaixados em classificação AA, A, B, etc., baseados em classificações criadas a partir das tendências do mercado e pesquisas publicadas por empresas, tais como, Colliers Internacional ${ }^{5}$ (Tabelas1 e 3) e Instituto ILOS (Tabela 2).

\begin{tabular}{|l|l|l|l|l|}
\hline \multicolumn{1}{|c|}{ Classificação } & $\mathrm{A}+$ & $\mathrm{A}$ & $\mathrm{B}$ & $\mathrm{C}$ \\
\hline Ar Condicionado & & & & \\
\hline Sprinklers & & & & \\
\hline Pé direito H=12m & & & & \\
\hline Pé direito H=9m & & & & \\
\hline 1 Doca a cada $1.000 \mathrm{~m}^{2}$ & & & & \\
\hline Capacidade do piso > 6 ton/m² & & & & \\
\hline Piso nivelado a laser & & & & \\
\hline Telhado de cimento amianto & & & & \\
\hline Pátio de manobras & & & & \\
\hline Piso Anti-Estático & & & & \\
\hline
\end{tabular}

Tabela 1 - Critérios de classificação de condomínios logísticos de acordo com Colliers Internacional

Fonte: Colliers Internacional (2010b)

\footnotetext{
4 "atuantes do mercado" será a palavra usada para denotar os envolvidos ou competidores dentro do mercado de Real Estate.

${ }^{5}$ A empresa Colliers internacional é uma das maiores atuantes no mercado de CL.
} 


\begin{tabular}{|c|c|c|c|}
\hline \multirow{6}{*}{ INFRAESTRUTURA } & Balança de pesagem & $\begin{array}{l}\text { _Área de apoio ao } \\
\text { motorista }\end{array}$ & $\begin{array}{l}\text { _Extensa área de } \\
\text { manobra }\end{array}$ \\
\hline & Terminal ferroviário & $\begin{array}{l}\text { _Estacionamentos } \\
\text { Rotativos e } \\
\text { privativos }\end{array}$ & _Posto de combustível \\
\hline & _Heliporto & _Tranporte coletivo & $\begin{array}{l}\text { _Borracharia/Oficina } \\
\text { mecânica }\end{array}$ \\
\hline & _Salas de reunião & $\begin{array}{l}\text { _Caixa de agua } \\
\text { individual }\end{array}$ & Enfermaria \\
\hline & $\begin{array}{l}\text { _Auditorio para } \\
\text { palestrantes e treinamento }\end{array}$ & $\begin{array}{l}\text { _Infraestrutura de } \\
\text { comunicação }\end{array}$ & $\begin{array}{l}\text { _Sistemas de proteção } \\
\text { contra incêndio }\end{array}$ \\
\hline & _Geradores & & \\
\hline & $\begin{array}{l}24 \text { horas. } 7 \text { dias } \\
\text { p/semana }\end{array}$ & _Controle de acesso & _Dilacerador de pneus \\
\hline SEGURANÇA & _Circuito fechado TV & _Guarita blindada & _Eclusa para carretas \\
\hline ADMINISTRAÇÃO & _Manutenção predial & $\begin{array}{l}\text { _Limpeza de área } \\
\text { común }\end{array}$ & $\begin{array}{l}\text { _Paisagismo e } \\
\text { jardinagem }\end{array}$ \\
\hline SERVIÇOS & _ Central de copias & _Caixas eletrônicos & \\
\hline LAZER & _Quadra poliesportiva & $\begin{array}{l}\text { Sala de } \\
\text { convivencia }\end{array}$ & \\
\hline ALIMENTAÇÃO & _Restaurantes & $\begin{array}{l}\text {-Refeitorios } \\
\text { coletivos }\end{array}$ & _Cozinha industrial \\
\hline \multirow{3}{*}{ SUSTENTABILIDADE } & _Reuso de aguas pluviais & $\begin{array}{l}\text { _Utilização de luz e } \\
\text { ventilação naturais }\end{array}$ & $\begin{array}{l}\text { _Coleta seletiva de } \\
\text { lixo }\end{array}$ \\
\hline & _Paneis solares & $\begin{array}{l}\text { _Equipamentos de } \\
\text { redução de } \\
\text { consumo de energia } \\
\text { elétrica e agua }\end{array}$ & $\begin{array}{l}\text { _Sistema de } \\
\text { monitoramento remoto } \\
\text { do consumo de energia } \\
\text { e agua }\end{array}$ \\
\hline & _Tratamento de esgoto & _Certificação LEED & \\
\hline
\end{tabular}

Tabela 2 - Exemplos de serviços encontrados nos principais condomínios logísticos classe A ou A+, segundo instituto ILOS.

Fonte: Instituto ILOS 


\begin{tabular}{|l|l|l|l|}
\cline { 3 - 4 } & \multicolumn{2}{|c|}{ A } & \multicolumn{2}{c|}{ B } \\
\hline 1 & Pé direito & superior ou igual a 9m & por volta de 8m \\
\hline 2 & Cobertura & Manta e telha com isolamento & Amianto ou galvanizada \\
\hline 3 & Vão livre & $15 \mathrm{~m}$ & inferior a $15 \mathrm{~m}$ \\
\hline 4 & Doca & sim & sim/não \\
\hline 5 & Pátio de estacionamento & sim & sim/não \\
\hline 6 & Área de galpão & $4000 \mathrm{~m}^{2}$ & Inferior a 4000m ${ }^{2}$ \\
\hline 7 & Localização & Em loteamentos ou condomínios (indispensável) & Fora de loteamentos ou condomínios \\
\hline 8 & Vias de acesso & Primarias & Secundárias \\
\hline 9 & Serviços adicionais & Escritórios, accesso a linha férrea & Escritorios \\
\hline 10 & Sistema contra incêndio & Detecção automatizada & Hidrantes \\
\hline 11 & Resistencia do piso 0 & 5 tineladas por m ${ }^{2}$ & - \\
\hline 12 & Fechamentos & Tilt-up & Painel de concreto \\
\hline 13 & Idade & Inferior a 10 anos & superior a 10 anos \\
\hline
\end{tabular}

Tabela 3 - Critérios de avaliação de condomínios logísticos de acordo com Colliers Internacional

Fonte: Colliers Internacional (2010b)

Assim, o que vige hoje no mercado são declarações pouco fundamentadas pelas partes interessadas com respeito à classificação dos CL. A informação a respeito da classe do empreendimento oferecida aos usuários carece de embasamento metodológico. Os grupos de atributos avaliados não contam com uma hierarquia de classificação específica, robusta e imparcial, que ofereça respaldo aos usuários, o que manifesta a notória ausência de um sistema de classificação, no qual se adote critérios mais bem fundamentados e com análise do estado dos atributos, sob o ponto de vista do usuário. Esta avaliação dos atributos deveria obter pontos mediante avaliação criteriosa e objetiva, enquadrada em certa escala de classificação, definindo assim uma classificação hierarquizada do CL, com o objetivo de enquadrá-lo dentro de uma classe que estabeleça uma determinada categoria, consolidada por um comitê de classificação que aprovaria e certificaria sua inserção numa certa classe ou nível de qualidade.

A pesquisa desenvolve uma metodologia na qual os empreendimentos de condomínios logísticos são avaliados por meio de critérios hierarquizados que analisam o estado dos atributos, tanto fundamentais como diferenciais, desde o ponto de vista dos usuários. Desta forma, cada um destes atributos obtém uma avaliação expressa através de pontos conferidos 
aos mesmos. Estes pontos são enquadrados em certa escala de classificação, que permita definir uma classificação hierarquizada para o condomínio logístico. Cada galpão e o condomínio em geral podem ser inseridos no sistema de certificação em determinada categoria para posteriormente ser consolidada por um comitê de classificação que emite um certificado que define essa inserção.

\subsection{Objetivos Gerais e Específicos.}

Diante do exposto sobre os critérios existentes no mercado para classificar CL dentro das empresas atuantes, o objetivo geral da pesquisa é desenvolver um sistema de certificação da qualidade de CLs no Brasil, no qual sejam identificados e analisados os diferentes atributos que enquadram um empreendimento dentro de uma classe específica, para dar suporte a uma leitura de qualidade nos empreendimentos pelo mercado.

Adicionalmente, a pesquisa visa apresentar esta certificação dentro dos parâmetros e com apoio do Núcleo de Real Estate da Escola Politécnica da Universidade de São Paulo (NRE/POLI/USP), com o objetivo específico de ser oferecida a todo o mercado nacional pelo mesmo NRE/POLI/USP, após apresentação e publicação da pesquisa desenvolvida na dissertação de Mestrado que abrange este tema.

Os objetivos específicos da pesquisa são:

i) Gerar uma matriz de atributos a partir dos indicadores de qualidade coletados na pesquisa.

ii) Definir uma escala de classificação a partir da hierarquia dos atributos gerada a partir dos questionários, "feedback", e da técnica de análise.

Estabelecimento do comitê de classificação para julgar a inserção do CL analisado no sistema de classificação segundo certa categoria.

6 Feedback significa retroalimentação em português e, dentro do contexto desta pesquisa, representa a informação de saída produzida por um sistema de informação que, na etapa seguinte, passa a ser dado de entrada do sistema. No entanto, a frequência do uso do termo em inglês consagrou-o, o que justifica seu emprego ao longo deste estudo. 


\subsection{Metodologia}

Para atingir o objetivo da presente pesquisa, foi elaborada a metodologia descrita a seguir:

i) Identificação dos aspectos comuns quanto às classificações existentes no mercado brasileiro de CL segundo as empresas especializadas no setor

ii) Uso de processo empregado para gerar ideias e obter convergência de opiniões (técnica Delphi), a qual coleta e confronta sistematicamente julgamentos sobre o tópico em estudo de participantes anônimos e isolados fisicamente.

iii) Seleção dos participantes da pesquisa (mínimo 10 e máximo 50) (especialistas da área que têm proximidade à questão em discussão e participam do processo Delphi).

iv) Modelagem do processo Delphi.

v) Entrevistas com os participantes selecionados, para definir seu interesse em participar da pesquisa e discutir os aspectos técnicos relacionados a CL.

vi) Visitas técnicas aos CLs consolidados das empresas participantes da pesquisa.

vii) Arbitragem inicial da matriz de atributos.

viii) Entrega dos questionários de pesquisa (rodada inicial).

ix) Coleta e analise dos dados.

x) Melhora da matriz e aplicação da segunda rodada (final).

xi) Coleta e analise dos dados da segunda rodada, elaboração da matriz definitiva e construção da escala de classificação para possibilitar a entrega do modelo de Certificação da qualidade.

xii) Aplicação da Matriz e calibragem da escala de valores.

xiii) Definição das classes segundo a escala de Valores.

\section{Identificação Dos Aspectos Comuns Quanto Às Classificações Existentes No Mercado De}

\section{CL segundo as empresas especializadas no setor:}

O levantamento bibliográfico efetuado reconhece uma serie de aspectos comuns que são citados como qualidade dos CL, estes aspectos são apresentados como uma seleção de ideias para uma formação de critérios com respeito aos CL. Pretendesse mostrar definições, desenvolvimento do mercado de CL nos últimos anos no Brasil e as classificações dadas pelo próprio mercado, segundo atributos arbitrados como sendo referências de qualidade. 
Características sugeridas ou implantadas pelos Participantes do Mercado Brasileiro de Condomínios logísticos (PMBCL) ${ }^{7}$, além dos últimos informes de tendências do mercado.

\section{Uso e Processo Para Gerar ideias e Obter Convergência (Técnica Delphi).}

Existem varias técnicas que podem ser empregadas para comparar características associadas em um determinado produto. Dentro de um mercado no qual são oferecidas diversas características associadas ou sinalizadas como fatores de qualidade se faz necessário distinguir as opiniões prevalentes no meio especializado. Utilizando o processo Delphi, combinado com técnicas da Estatística Descritiva é possível, detectar estas opiniões. A técnica Delphi, foi utilizada por Veronezi (2004) para desenvolver um "Sistema de Certificação da qualidade de edifícios de escritório no Brasil”, dentro do Núcleo de Real Estate da escola Politécnica da Universidade de São Paulo (NRE/POLI/USP); hoje esta certificação de edifícios de escritório é oferecida e requisitada pelo mercado. O Sistema de certificação da qualidade de edifícios de escritórios do NRE/POLI/USP é entendido como referencia isenta para se avaliar a qualidade destes empreendimentos devido à metodologia de pesquisa que deram suporte à sua criação. A mesma técnica Delphi utilizada por Veronezi (2004) será empregada neste trabalho, tendo em vista não os mesmos requisitos de convergência de opinião exigidos aqui, tal qual lá, como também na efetividade dos resultados alcançados no processo de construção daquele sistema como da sua utilização hoje no meio do real estate.

Aliás, como complemento, é importante fixar que ao se ter um estudo que envolve a geração de ideias, a técnica Delphi pode ser considerada como uma tática para abordar as questões. Mediante esta técnica, é possível atingir a máxima convergência das respostas, para alcançar o objetivo em estudo. Isto será discutido com profundidade Capítulo 5 Seleção da Técnica Delphi Para O Desenvolvimento de Sistema de Certificação.

\footnotetext{
${ }^{7}$ PMBCL, é um termo muito usado no presente trabalho, devido a isso se adota o uso das siglas.
} 
Seleção Dos Participantes Da Pesquisa (mínimo 10 e máximo 50).

Esta seleção foi feita de maneira arbitrada, levando em consideração vários atuantes do setor, entre eles projetistas, arquitetos, empreendedores, investidores e usuários, todos eles orientados a participar da pesquisa colocando sua opinião desde o ponto de vista do usuário.

Foram contatados 42 participantes, dos quais 30 mostraram interesse em participar e responderam a primeira rodada do questionário de pesquisa. Para a segunda rodada foi enviado um questionário particular a cada um dos 30 participantes, dos quais responderam 15.

\section{Modelagem Da Técnica Delphi.}

A modelagem da técnica Delphi neste trabalho foi espelhada na construção do sistema de Certificação da qualidade de edifícios de escritório no Brasil, Veronezi (2004). Como ponto de partida foram adotados aqueles atributos da matriz de Veronezi (2004), que encaixavam como parte dos projetos de CL, para logo acrescentar os atributos obtidos na pesquisa bibliográfica do mercado de CL tanto do Brasil como de outros países, sempre conservando o modelo citado, tanto da matriz como do questionário de pesquisa. Pois, a técnica Delphi descreve que quanto mais avançado seja o questionário inicial da pesquisa, maior a convergência das rodadas, como o apresentado na pesquisa utilizada como modelo.

\section{Entrevistas Com Os Participantes Selecionados, Para Definir Seu Interesse Em Participar} Da Pesquisa e discutir os aspectos técnicos relacionados a CL.

Antes de iniciar a aplicação do Delphi, foram solicitadas as entrevistas com os PMBCL para apresentar a pesquisa, saber do seu interesse em participar e discutir sobre as características técnicas e de funcionamento dos CL. Nestas entrevistas foram discutidos muitos dos parâmetros a respeito dos atributos que deveriam ser incluídos na pesquisa de mercado.

\section{Visitas Técnicas Aos CL Consolidados Das Empresas Participantes Da Pesquisa.}

Após as entrevistas com os PMBCL ficou definido o interesse de participação na pesquisa e foram agendadas visitas técnicas a diferentes condomínios logísticos localizados próximos à cidade de São Paulo, Brasil, nas zonas alvo deste tipo de empreendimento nos últimos anos, tais como: Campinas, Jundiaí, Guarulhos, Grande ABC, Louveira, Embu, Cajamar, etc., todos 
eles articulados as principais rodovias de acesso da Grande São Paulo (rod. Anhanguera, rod. Dutra, rod. Castelo Branco, rod. Bandeirantes, rod. Imigrantes, etc.).

\section{Arbitragem Da Matriz De Atributos.}

No momento de selecionar os atributos que deveriam compor a primeira versão da matriz de atributos, o primeiro passo foi adotar o modelo apresentado por Veronezi (2004), ao analisar esta matriz modelo foi possível selecionar tanto os itens que podiam permanecer, como os que evidentemente precisavam ser removidos. A partir de ali foram inseridos os itens identificados na bibliografia e mercado de CL. Todos esses atributos foram organizados em subsistemas que identificam sua origem ou função. Esta matriz inicial foi depurada com as entrevistas aos PMCLB e as visitas técnicas a projetos consolidados e inseridos no mercado de CL do Brasil Esta matriz arbitrada foi encaixada num questionário de avaliação e enviada para os PMCLB, com as respetivas orientações.

\section{Entrega Dos Questionários De Pesquisa (Rodada Inicial).}

Os questionários foram enviados via internet a todos os participantes selecionados, junto com o questionário foi descrita a pesquisa de maneira sucinta e com as devidas orientações de preenchimento e tempos de entrega.

Análise das Respostas, Revisão das Arbitragens Iniciais, por meio de Avaliação e Calibragem, Entremeadas com Sucessivos Ajustes das seguintes Rodadas.

Após cada rodada, os questionários recebidos foram analisados, todas as respostas estruturaram uma análise estatística das respostas. A estatística da primeira rodada indicou uma convergência satisfatória das respostas, e nos casos onde as respostas ficavam fora do padrão de dispersão foi feita uma segunda consulta à respeito da opinião. Aja à na segunda rodada, a análise estatística indicou uma convergência de respostas tal que dispensou uma terceira rodada.

Estrutura Definitiva da Matriz de Atributos.

A matriz de atributos, que forma parte do sistema de classificação, foi estruturada a partir da opinião prevalente de usuários e atuantes do mercado de Condomínios Logísticos. Aqui a 
técnica Delphi foi empregada para obter uma hierarquia para cada atributo e para reduzir a variação de opiniões entre os envolvidos nesta pesquisa.

Neste estudo, a opinião prevalente buscada no mercado brasileiro de condomínios logísticos se refere a quais atributos deveriam compor a matriz e qual a escala de importância de cada um deles em relação aos demais, com o fim de atingir uma classificação por classe.

Para definir os atributos que estruturam a matriz definitiva desta pesquisa, foi analisada cada rodada, empregando-se técnicas da Estatística Descritiva e a técnica Delphi, que mostrou o Fator de importância relativa ${ }^{8}$ de cada componente em relação aos demais.

Na segunda rodada se fez a consulta respeito da importância (Fator de Importância Relativa) que os participantes davam a cada subsistema (grupo de atributos), com esta ponderação e os valores obtidos como fator de importância para cada atributo foi estrutura da matriz de avaliação, na qual, são apresentados todos os atributos julgados como pertinentes para classificar CL, seu fator de importância, o fator de importância do grupo ao qual pertence e as notas esclarecedoras para a escala de pontuação.

\section{Aplicação da Matriz e Calibragem da Escala de Valores.}

A matriz definitiva permitiu fazer o exercício de avaliar vários prédios escolhidos e assim obter diferentes notas de classificação que ao serem comparadas e estudadas permitiram estabelecer escalas de classificação que junto com o regulamento e o comitê de classificação espelhado no certificado de qualidade de Veronezi (2004) fundamentam e determinam a classificação do galpão avaliado.

Dentro da Matriz, cada um dos atributos possui seu respetivo Fator de Importância Relativa (FIR) e pertence a um subsistema de avaliação. Cada subsistema possui também seu próprio FIR que pondera o valor global que deve ser atribuído a cada atributo, tal como apresentado posteriormente no Capítulo 7.

Após a aplicação da Matriz em vários galpões que, segundo nosso critério, representam os diferentes extremos das classes procuradas como escala de classificação, foi identificado o espectro de valores onde serão encaixadas as classes definidas no Capítulo 7.

\footnotetext{
${ }^{8}$ O Fator de Importância Relativa indica o grão de importância que cada atributo e/ou subsistema possui
} segundo a análise das respostas dos participantes da pesquisa 
Ao final, foram definidas quatro Classes de Galpão, cada uma compreendida dentro de um intervalo de valores que define sua classificação nacional. Assim, ratifica-se o objetivo de oferecer um certificado da qualidade de condomínios logísticos como serviço do Núcleo de Real Estate da Escola Politécnica da USP, que estará à disposição do mercado nacional brasileiro, após apresentação e publicação desta Dissertação.

\subsection{Estrutura do Sistema de Certificação de Qualidade de Condomínios Logísticos no Brasil.}

Tal como já foi mencionada, a estruturação deste Sistema de Certificação está espelhado na proposição do Sistema de Certificação de Veronezi (2004), assim, foi mantida essa mesma estrutura segundo se apresenta a seguir:

i) Sistema de classificação: os empreendimentos de condomínio logístico são classificados conforme o estado de atributos e grupos de atributos que compõem a matriz de atributos do sistema, tanto dos galpões em particular quanto do conjunto de elementos presentes nas áreas comuns do condomínio em análise;

ii) Emissão de um certificado: um membro do Núcleo de Real Estate da Escola Politécnica da USP realiza uma vistoria e análise do empreendimento e define a inserção de cada galpão no sistema de classificação segundo certa categoria / classe;

iii) Procedimento para verificação da validade deste certificado; e

iv) Estrutura para atualização do sistema de classificação.

Ao se implantar um Sistema de Certificação deve se ter presente que a qualidade de um empreendimento pode se ver afetada com o tempo (perecibilidade), por este motivo se dispõe dos dois últimos itens, iii e iv, como partes integrantes do sistema proposto.

O Sistema de classificação apresentado como um dos subsistemas do Sistema de Certificação da qualidade de condomínios logísticos está composto por:

i.1. matriz de atributos;

i.2. escala de classificação; e

i.3. comitê de classificação. 
Conforme já mencionado, o Sistema de Certificação aqui proposto tem como base à dissertação de mestrado "Sistema de Certificação da Qualidade de Edifícios de escritórios no Brasil”, Veronezi (2004), considerando que, o Sistema de Certificação da Qualidade de Edifícios de Escritórios no Brasil do NRE/POLI/USP tem satisfatoriamente atendido o setor desde a sua implementação em 2004, já tendo certificado 61 empreendimentos envolvendo aproximadamente 860.000 metros quadrados de área de locação, e que na revisão da literatura não se encontrou nenhuma referência válida no intuito de oferecer um novo e similar serviço para o segmento de Condomínios Logísticos no Brasil, foi adotada como base para o desenvolvimento da presente pesquisa e foram seguidos os mesmos passos e regulamentos ali sinalizados, assim como também as normas.

Desta forma e conforme se mostra a seguir, este Sistema de Certificação está fundamentado em:

pesquisa bibliográfica;

entrevistas aos especialistas, participantes do mercado de condomínios logísticos no Brasil-PMCLB's';

visitas a CL do segmento enfocado;

observações realizadas no mercado de CL do Brasil;

arbitragens iniciais, seguidas de testes de validação e calibragem entremeados com sucessivos ajustes.

Após observar o comportamento do mercado e logo de varias entrevistas com PMCLB, foram estabelecidas arbitragens que logo recebem validação e calibragem ao estabelecer e aplicar a matriz de atributos.

A primeira e a segunda rodadas do questionário (baseado na matriz de atributos arbitrada) fundamentam os critérios necessários para estabelecer a escala de classificação e a matriz definitiva, que são importantes componentes do Sistema de classificação, subsistema do Sistema de Certificação geral.

9 A sigla PMCLB foi aqui criada para substituir o termo "participante do mercado de condomínios logísticos do Brasil", que é muito longo e é repetidamente empregado ao longo desta Dissertação. 
Para corrigir e estabelecer a matriz de atributos definitiva, o primeiro passo foi a detecção das opiniões e atributos predominantes dentro do mercado especializado, por meio da aplicação de questionários em duas diferentes rodadas. A cada rodada se fez a análise de cada uma das respostas dos participantes e a partir da convergência das respostas foram estabelecidos os atributos e/ou subsistemas com maior ou menor Fator de Importância Relativa, como resultado do processo Delphi empregado, além da utilização de técnicas de estatística descritiva até estruturar a Matriz de atributos definitiva, como posteriormente será explicado nesta Dissertação.

Após estruturar a Matriz de atributos definitiva, esta foi aplicada em galpões cujo estado dos respectivos atributos de qualidade evidenciavam o piso e o teto de qualidade de empreendimentos no mercado, de acordo com os critérios da Matriz. Desta maneira foram identificados os parâmetros numéricos, do piso e do topo da Matriz de Classificação . A seção 4.2 destina-se à Arbitragem das escalas de classificação. Desta forma foi avaliado o CL Cajamar Industrial Park pertencente à empresa Prologis CCP, o qual conta com sete (7) galpões, sendo que o menor deles tem área construída de $17.510 \mathrm{~m}^{2}$ e o maior deles $36.090 \mathrm{~m}^{2}$ e o CL Santo André, pertencente à empresa Palmar que conta com três galpões e uma área construída de $30.778 \mathrm{~m}^{2}$.

Depois da análise e classificação hierarquizada dos galpões pertencentes ao CL, por meio do emprego do Sistema de classificação, será emitido um certificado de qualidade individual para cada galpão avaliado dentro de um mesmo condomínio, sob a chancela do Núcleo de Real Estate da Escola Politécnica da USP, definindo a inserção de cada Galpão no Sistema de classificação segundo certa categoria / classe.

Cada Galpão analisado obtém uma classificação nacional, na qual esta inserida a nota do conjunto de atributos de galpão junto com a nota dada aos atributos do condomínio em geral. São considerados tanto os atributos físicos do empreendimento como sua localização tanto no que diz respeito às distâncias e tempos para deslocamento aos grandes centros consumidores, quanto ao que se refere ao estado do sistema rodoviário do seu entorno.

Na atualidade, empresas de comercialização dos empreendimentos utilizam uma diversidade de Sistemas de classificação para fazer referência à qualidade dos empreendimentos, as ditas categorias são reconhecidas com a simbologia AAA para qualidade superior, passando por A, B e C, conforme o padrão de qualidade percebido e oferecido aos usuários. 
Os atributos embarcados nos empreendimentos que referenciam a sua qualidade deverão ter forte correlação com os indicadores do mercado, como valor de locação, taxa de ocupação, etc. A oferta diferenciada na composição de atributos de qualidade de empreendimentos está voltada em oferecer infraestrutura focada em diversos estratos ou demandas dos usuários. Uma eventual segmentação ou estratificação destes padrões de qualidade geram, por si só, maior informação para os agentes do mercado.

Um sistema de Certificação da Qualidade consegue posicionar as informações para suportar a tomada de decisão relacionada com a eleição de um galpão em uma determinada região do país.

O mercado imobiliário de CL pode aceitar e adotar este sistema de Certificação da Qualidade, a partir da confiabilidade que pode identificar nele. Por este motivo, dentro do texto se inclui enfaticamente as questões de imparcialidade da certificação, assim como o compromisso de atualização periódica e designação do prazo de validade do mesmo. 


\section{ESTADO DE ARTE}

\subsection{O mercado de condomínios logísticos.}

\subsubsection{Conceituação do mercado}

Com o fim de mostrar a importância da criação de um sistema de certificação para condomínios logísticos, estes últimos serão brevemente conceituados dentro do mercado imobiliário do Brasil.

Importante ressaltar que a pesquisa foi elaborada tentando obter o ponto de vista do usuário, $\mathrm{o}$ que define ou limita sua abrangência ao mercado brasileiro.

Existem variados termos ligados ao presente estudo que precisam ser definidos, aprofundados e inclusive comparados. Entre os termos mais comuns que precisam ser definidos, estão: Condomínio Logístico, condomínio industrial, plataformas logísticas e galpões isolados.

\section{- Condomínio Logístico.}

A partir da definição de Condomínio Logístico, delimita-se a amplitude desta pesquisa, pois fica definido o tipo de edifício que se busca enquadrar dentro do sistema de certificação de qualidade.

O conceito de propriedade em condomínio demarca a primeira pauta, pois ela denota um conjunto de proprietários. A definição de condomínio segundo MICHAELIS -dicionário da língua portuguesa- é:

\footnotetext{
1 Domínio que pertence a duas ou mais pessoas juntamente.2 Direito de soberania exercido por duas ou mais potências sobre uma região. 3Coisa indivisa (prédio), cuja propriedade está dividida entre duas ou mais pessoas.4 Patrimônio dos fundos de investimentos. C. fechado: condomínio protegido por sistemas de segurança que controlam o acesso de pessoas e veículos às suas dependências.
}

Ou seja, ao se tratar de Galpões dentro de Condomínios Logísticos deve se ter presente as características das propriedades em condomínio, onde diferentes usuários utilizam áreas comuns ou de apoio, assim como segurança e paisagismo.

Em seguida, ao definir o conceito de logística, fica delimitada a abrangência da presente pesquisa. 
O dicionário de Tecnologística online (2016), define logística como: "a arte de administrar os negócios de forma integrada, otimizando os recursos disponíveis, visando o ganho global no processo". Portanto, o setor de logística se interessa em realizar seus processos, sejam de armazenagem ou distribuição, de maneira eficiente.

Os conceitos anteriormente citados podem dar origem a uma definição de CL, devidamente integrada ao desenvolvimento desta pesquisa. Desta maneira, CL pode ser definido como uma área comum, dentro de um conjunto fechado, onde vários usuários compartilham um sistema de segurança com acesso controlado, que dispõe de edifícios planejados para administrar negócios de forma integrada e que, aliás, conta com recursos que visam aperfeiçoar os processos para assim gerar um ganho global.

Algumas grandes empresas ou PSL que trabalham com varejo possuem seus próprios centros logísticos, porem, outras muitas empresas preferem operar em locais alugados e enfrentam variados tipos de dificuldades para localizarem seus estoques para distribuição, desde aluguéis altos em regiões muito valorizadas, até grandes custos fixos com segurança e manutenção. Portanto, segundo DINIS; RIGHI, (2013), surgem os CL, seguindo o mesmo conceito dos condomínios residenciais ou centros comerciais, aproveitando oportunidades de terrenos baratos e com boa acessibilidade, a maioria encontrada nas áreas ao redor das principais rodovias que acessam grandes centros urbanos, como São Paulo.

Conforme o instituto ILOS (2012), caracteriza-se um CL como "Uma estrutura voltada à armazenagem a qual está organizada em módulos, que compartilham infraestrutura com oferta de serviços especiais e cujos custos são compartilhados entre os usuários".

Dias (2011), apud Kimimoto, Relva, Junior (2014) define um CL como:

O conjunto de diversos galpões com flexibilidade de modulação de espaços situados em um único terreno. Foi desenvolvido para proporcionar ganhos de escala para operadores logísticos, transportadoras, indústrias e varejistas, atendendo às necessidades de armazenagem e distribuição. Tem como objetivo oferecer uma infraestrutura de serviços compartilhados, integração logística, redução de custos nos estoques, instalações e processos.

Tachibana, 2013. No estudo de caso de condomínio logístico em Ribeirão Preto - SP, disse:

Os condomínios logísticos se enquadram no grupo dos empreendimentos de base imobiliária, onde a receita é oriunda da renda a partir dos contratos de alugueis firmados com múltiplos inquilinos que utilizam o imóvel como estrutura e abrigo 
para o funcionamento de suas atividades econômicas relacionadas a atividades industriais leves ou de logística. Compõe o leque de usuários destes condomínios: empresas de logísticas terceirizadas, centros de distribuição de empresas varejistas, pequenas linhas de montagens e distribuições alimentícias.

E como complemento ao conceito de CL, Poletto, (2011), cita uma tipologia chamada condomínios logísticos modulares que descreve claramente os empreendimentos alvos da presente pesquisa.

Esta tipologia de condomínios logísticos modulares, segundo Poletto (2011), apresentam características de flexibilidade na locação. Esta flexibilidade refere-se ao fato de contar com áreas de aluguel em módulos contíguos, que permite atender maior variedade de usuários (atendendo o binômio preço vs. qualidade), onde os usuários podem contar com maior área para armazenagem ao ter pé direito elevado, mezanino para instalação de escritórios, docas elevadas, muitas vezes com niveladores, além de piso com alta resistência às cargas. Todo o conjunto de atributos e planejado para atrair desde empresas de logística até indústrias de alta tecnologia ou montagem de equipamentos.

\section{- Condomínio Industrial}

Este tipo de condomínio não faz parte do foco desta pesquisa, porém os CL podem alojar espaços para indústrias com processos simples que se adaptem dentro dos galpões oferecidos. Por este motivo é citada esta modalidade de empreendimento.

Os primeiros condomínios industriais surgiram na década de 1990, e representam a superação e adequação à nova realidade econômica dos velhos distritos industriais como supridores de áreas ao desenvolvimento industrial. Assim, do projeto público passa-se ao empreendimento privado. Essas novas iniciativas têm configurações criteriosamente estudadas para alojar os fornecedores parceiros, visando à redução de custos com estoques e transporte, viabilizando os modelos de terceirização que integram os fornecedores com as montadoras, mantendo estas últimas gestoras e controladoras do processo de produção, comercialização e expedição. Se produzidos longe da montadora, muitos componentes apresentariam custos logísticos elevados, por exemplo, em razão de sofisticadas embalagens, quando frágeis, ou por causa dos elevados custos de transporte, quando volumosos, ocupando amplos espaços. As primeiras iniciativas nessa configuração, no Brasil, ocorreram com a indústria automobilística, podendo-se citar Volks-Audi, Volks- Resende, GM-RS e MB-MG. Hoje esse modelo flexível de produção, também difundido em outras áreas, como a de produtos 
eletroeletrônicos, pode ser encontrado em especial em indústrias localizadas na região de Campinas (VENANZI, 2008).

Poletto (2011) define que os galpões em loteamentos industriais/ logísticos são empreendimentos desenvolvidos em uma grande área já loteada, na qual esses lotes industriais/ logísticos são organizados e vendidos sob esta finalidade, contendo infraestrutura de vias pavimentadas próprias para suportar cargas pesadas e trânsito de veículos, guias, sarjetas e calçadas, galerias de águas pluviais, sistema coletor e de tratamento de esgotos, rede de água potável, energia elétrica e iluminação pública, sinalização, e até mesmo áreas verdes preservadas, onde cada empresa ou investidor responsabiliza-se pela construção de seu próprio galpão. Dentro deste tipo de empreendimento, comumente se constrói galpões por via de investidores que buscam alugar para um usuário final.

\section{- Galpões Isolados}

Poletto (2011) apresenta os galpões isolados como um tipo de empreendimento que mistura características tanto de condomínios logísticos modulares (galpões prontos para locação com relativa flexibilidade quanto ao seu uso), como também características de loteamentos industriais/ logísticos (com galpões construídos isoladamente para locação ou venda), e também contem áreas remanescentes para expansões futuras.

\section{- Plataformas Logísticas}

Boudouin (1996) define plataforma logística como um local de reunião de tudo o que diz respeito à eficiência logística, onde reúnem-se zonas de logística de empreendimentos e infraestruturas de transporte, que promovem a dinamização da economia, melhora a competitividade das empresas, cria empregos e viabiliza as atividades logísticas.

De acordo com TELECONTRANS (1999 upud Dubke, Ferreira, Pizzolato, 2004), "as plataformas logísticas são pontos ou áreas de rupturas das cadeias de transporte e logística, onde se concentram atividades e funções técnicas e de valor adicional".

Segundo Duarte (1999) apud Boudoin (1996), as plataformas logísticas contam com três subzonas com funções especiais: 
i) Subzona de serviços gerais: áreas que englobam recepção, informação, acomodação e alimentação, bancos, agência de viagens de estacionamento, abastecimento e reparos, serviços de alfândega, administração e comunicação.

ii) Subzona de transportes: que oferece infraestruturas para grandes eixos de transportes. Ressaltando a importância de contar com plataformas multimodais que possuam terminais multimodais, integrando transportes rodoviários, ferroviários, marítimos e aéreos.

iii) Subzona destinada aos operadores logísticos: que ofereça serviços de fretamento, corretagem, assessoria comercial e aduaneira, aluguel de equipamentos, armazenagem, transporte e distribuição.

\subsubsection{Gênese do setor}

Dentro do mercado de Real Estate do Brasil ainda é recente o conceito de Condomínio Logístico e por este motivo se faz necessário contextualizar este mercado desde diferentes pontos de vista que permitam entender seu desenvolvimento no país, desde sua concepção, características técnicas e crescimento até os assentamentos registrados e a competitividade setorial.

Segundo o Instituto de Logística e Supply Chain (ILOS, 2016), este tipo de empreendimento cresce de maneira significativa a partir da década dos 90 no Brasil, impulsionado principalmente pelos gargalos de transporte rodoviário nas grandes capitais e por outra parte, conforme dados apresentados pela empresa IVISTA (2016), o estoque de CL construído de 1970 a 2010 é praticamente o mesmo dos últimos seis anos, Figura 1.

Ou seja, o crescimento dos empreendimentos de base imobiliária no segmento logístico no Brasil é consequência de uma mudança de visão estratégica das empresas.

Num passado recente, as empresas que precisavam de galpões detinham a propriedade dos mesmos. Além da imobilização de capital para implantação dos galpões, as empresas tinham que gerenciar a construção e manutenção desses ativos ao longo do tempo. Essa estrutura de negócio demandava de cada empresa um setor de patrimônio e manutenção, gerando custos adicionais à operação de armazenagem, além da imobilização do capital. 


\section{Evolução do Estoque}

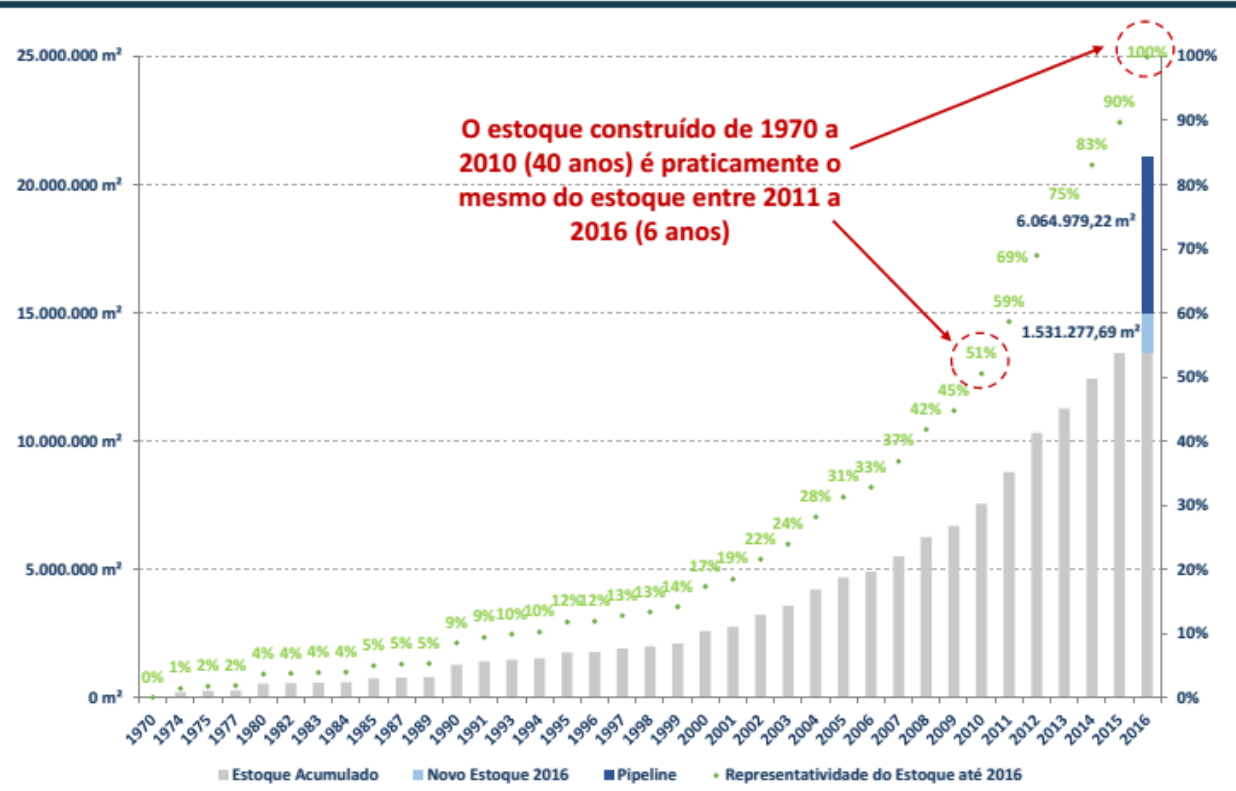

Figura 1 - Evolução do estoque de Condomínio Logístico no Brasil, Fonte IVISTA, (2016).

Com o amadurecimento das operações, as empresas industriais e do varejo entenderam que haveria uma redução de custos se toda essa operação logística fosse terceirizada a empresas especializadas nestas atividades. Segundo ILOS (2009, apud Panorama Terceirização Logística no Brasil 2009), em 2008 foi realizada uma pesquisa com 118 empresas de diversos setores de grandes grupos com presença no Brasil, a redução de custos é o fator principal para terceirização das atividades logísticas para $81 \%$ das empresas. Outras razões para a terceirização das atividades logísticas como foco no core business ${ }^{10}(73 \%)$, aumento nos níveis de serviço logístico (73\%), busca de maior eficiência na execução das atividades operacionais (73\%), redução dos investimentos em ativos (72\%) e maior flexibilidade nas operações logísticas $(66 \%)$ também foram citadas pelas empresas como fatores determinantes para a terceirização das atividades logísticas.

10 Core business é um termo da língua inglesa que significa núcleo do negócio, por ser amplamente usado no setor foi mantido no texto. Core business significa a parte principal de um determinado negócio, é o ponto forte de uma empresa que deve ser trabalhado estrategicamente. Significa a parte central, principal de uma empresa, ou de uma área de negócios especificamente. 
Diante desta conjuntura, empreendedores e investidores de perfil conservador, com vocação para negócios de base imobiliária, enxergaram uma grande oportunidade na emergência desse novo segmento e de se especializar ainda mais e produzir empreendimentos desenhados para atender às demandas de logística e de armazenagem de grandes empresas.

Ainda falando do crescimento do setor de CL, segundo ILOS (2016) uma das principais razoes radica na localização dessas instalações, pois geralmente é privilegiada (próxima a grandes centros de consumo e produção e às margens de rodovias, ferrovias, portos e/ou aeroportos de grande circulação.

Assim, ao observar os assentamentos destes empreendimentos com grandes galpões instalados dentro de uma propriedade condominial temos que, segundo dados publicados pela empresa IVISTA (2016), na cidade de São Paulo são observados seis grandes eixos rodoviários de crescimento, figura 2.

\section{Estoque Atual até 2016 (Eixo Rodoviário)}

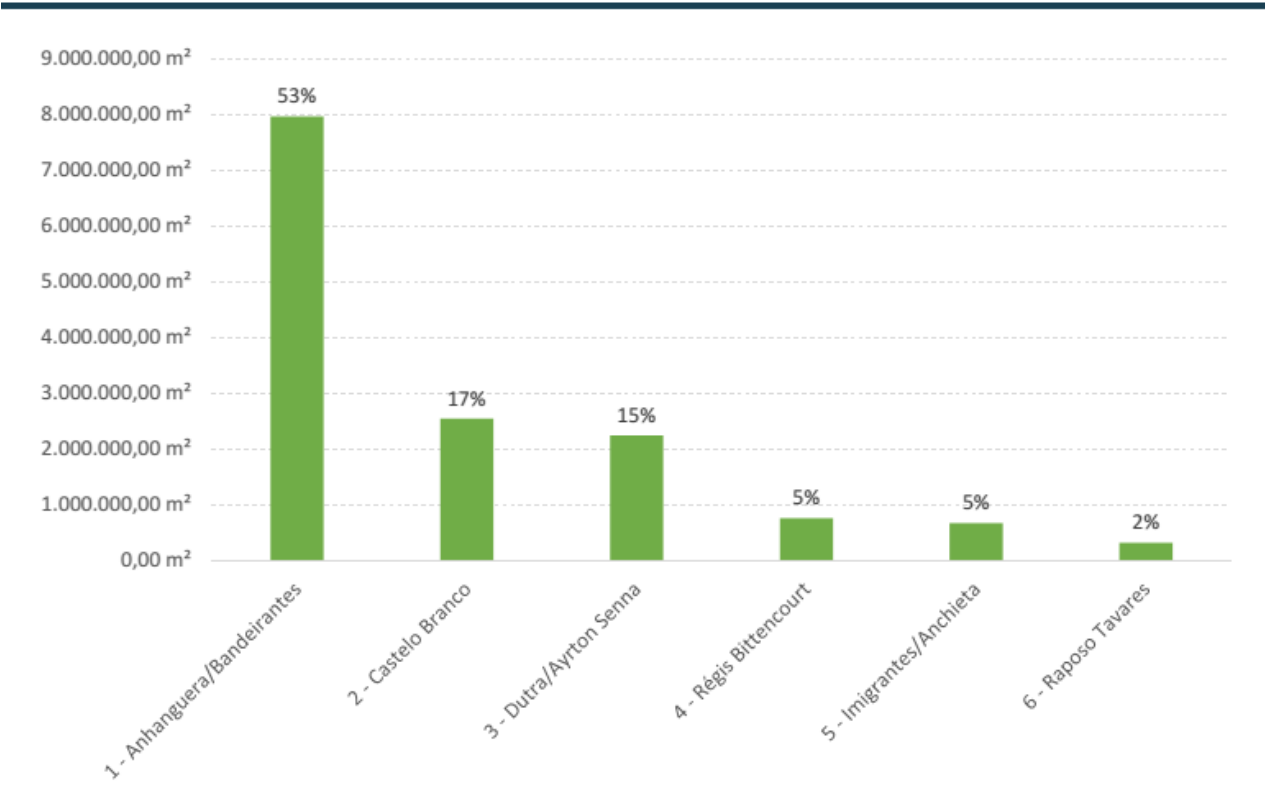

Figura 2- Estoque Atual de Condomínio Logístico na cidade de São Paulo, Fonte IVISTA (2016).

Em virtude do anteriormente exposto e conforme ILOS (2016), “dado o sucesso da lógica do CL foi inevitável que a ideia se expandisse. Houve logo uma fusão com a lógica dos polos de 
produção formando condomínios Industriais". Desta maneira a expansão e características dos CL apresenta empreendimentos que oferecem espaço para operações logísticas e industriais que contam com "escritórios comerciais, área residencial, e até lazer. São verdadeiras mini cidades, com toda infraestrutura necessária para a gestão de atividades de uma empresa no mesmo local".

\subsubsection{Comportamento setorial}

Os CL têm aumentado significativamente sua área de construção no Brasil, para cobrir uma demanda crescente e à procura de soluções de logística. Uma pesquisa realizada pelo Instituto de Logística e Supply Chain ILOS no ano 2012 apresentada na revista Tecnologística (2014 apud ILOS 2012 ) revelou o acelerado crescimento e desenvolvimento do mercado de CL no Brasil. Conforme dados levantados nesta pesquisa, a área de CL no Brasil aumentou em media $30 \%$ ao ano entre 2009 e 2011, passando de 3,4 milhões de $\mathrm{m}^{2}$ para 8,5 Milhões de $\mathrm{m}^{2}$ respectivamente. Figura 5 .

Este mercado crescente de CL tem chamado à atenção de desenvolvedores imobiliários, visando o crescimento das rendas e consequentemente do consumo que vem se observando em período recente, Tachibana (2013).

Ainda segundo Tachibana (2013), os CL constituem um mercado recente, o que faz com que a formatação dos negócios seja também bastante heterogênea.

Almi Imoveis Coorporativos (2013 apud Oliveira 2014) disse - conforme dados levantados na pesquisa que o crescimento da construção de CL no Brasil- esta tendência de crescimento deve-se ao surgimento no mercado dos grandes atuantes internacionais. Desta maneira registra-se que a área de CL passou de 8,5 milhões em 2011 para 9,554,000 m2 no terceiro trimestre de 2014

De acordo com o ILOS (2013), o mercado de condomínios logísticos está crescendo no Brasil, em grande parte acompanhando o desenvolvimento econômico do País. Com estrutura física e serviços compartilhados com outros usuários, os condomínios logísticos permitem flexibilidade para as empresas manterem seus estoques e centros de distribuição, reduzindo a imobilização do capital em instalações. 


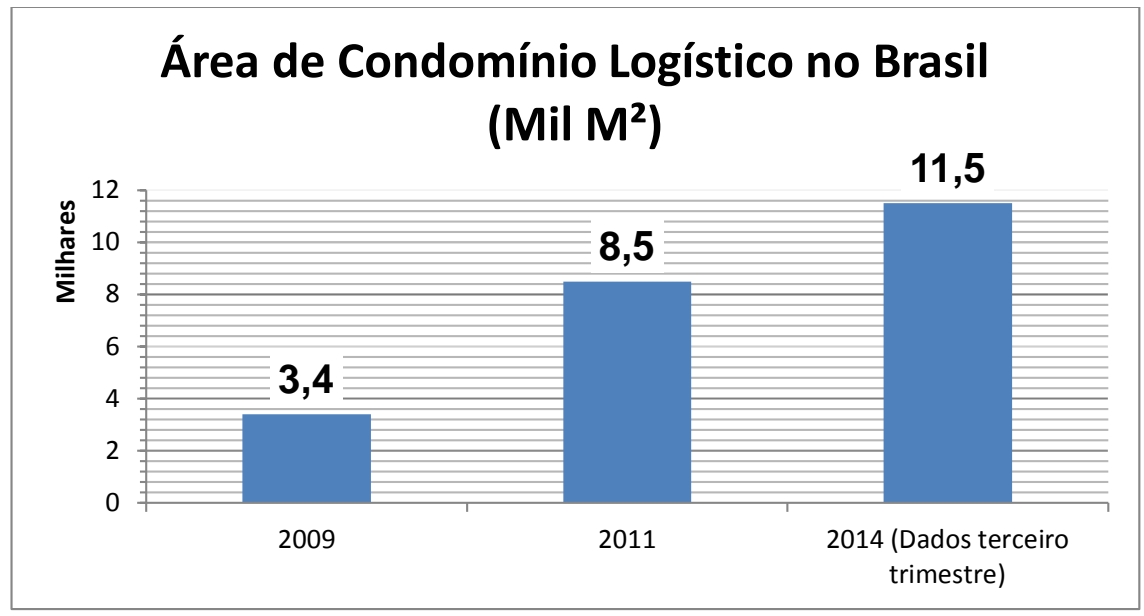

Figura 3 - Área de condomínios Logísticos no Brasil, construído pela autora, adaptado do ILOS (2012) e Colliers 2014.

O crescente interesse das empresas brasileiras em novos postos de armazenagem fez aumentar nos últimos anos os investimentos nos condomínios logísticos, que constituem grupos de galpões dedicados a atividades logísticas e industriais leves, contendo infraestrutura comum compartilhada pelas diversas empresas instaladas. O compartilhamento de serviços permite que os custos sejam rateados, o que muitas vezes viabiliza a utilização por empresas que não suportariam arcar com os custos de galpões individuais (ILOS, 2013).

Segundo Colliers International (2014), apesar dos indicadores econômicos desfavoráveis em relação aos anos anteriores, o mercado de condomínios logísticos apresenta um excelente desempenho se comparado a outros segmentos imobiliários.

Ainda conforme Colliers International (2014), até o terceiro trimestre daquele ano é evidente uma evolução dos projetos de CL considerados Classe A e a disseminação do conceito de condomínios logísticos por todo o País.

Apesar do acentuado crescimento do mercado de CL, é importante ter presente quais os setores do Brasil onde estão concentrados estes empreendimentos, pois a localização é um item importante dentro dos atributos de avaliação da qualidade. Desta maneira, segundo dados levantados pela Collierts international (2014), a região do mercado brasileiro com maior oferta de CL é o Sudeste, com uma participação no mercado de $7.578 .000 \mathrm{~m}^{2}$, seguida pelo 
Sul, com $747.000 \mathrm{~m}^{2}$, pelo Nordeste com $728.000 \mathrm{~m}^{2}$, pelo Norte com $225.000 \mathrm{~m}^{2}$ e por último Centro-oeste com $80.000 \mathrm{~m}^{2}$. Ver Figura 4.

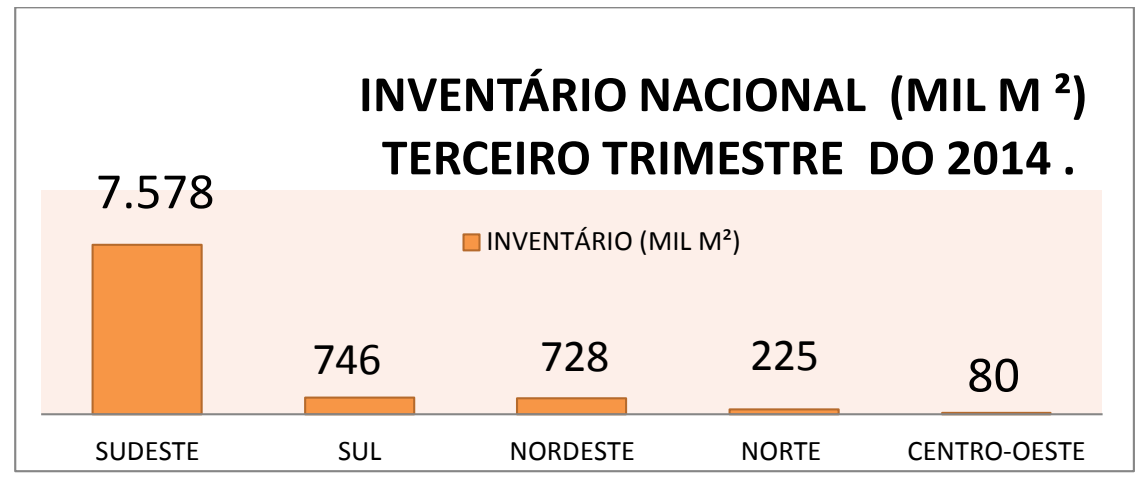

Figura 4 - Inventario Nacional de CL, construído pelo autor, adaptado de Colliers International (2014)

O informe do mesmo estudo citado acima ainda informa que a taxa de disponibilidade tem oscilado em torno de $18 \%$ desde o fim do ano 2013, fator que pode ser considerado positivo, dada a quantidade de área que o mercado logístico recebe a cada trimestre.

Quanto ao comportamento setorial referente ao tipo de clientes que preferem utilizar CL, fica concentrado no setor varejistas, de comercio eletrônico e de cosméticos. Segundo ILOS (2013).

No relatório do ano 2013 o Instituto ILOS descreve que os prestadores de serviços logísticos preferem escolher CL para atender seus principais clientes, os quais pertencem na sua maioria ao:
i) Comercio Varejista
ii) Eletroeletrônico e computação
iii) Higiene, Limpeza e Cosméticos.

Finalmente, ao se pesquisar sobre o tipo de empresa que procura o uso de CL, foi achado um informe de ILOS (2013), onde se mostra que os operadores logísticos que usam áreas em CL, são na sua maioria empresas de grande porte $(60 \%)$, ver figura 5 . 


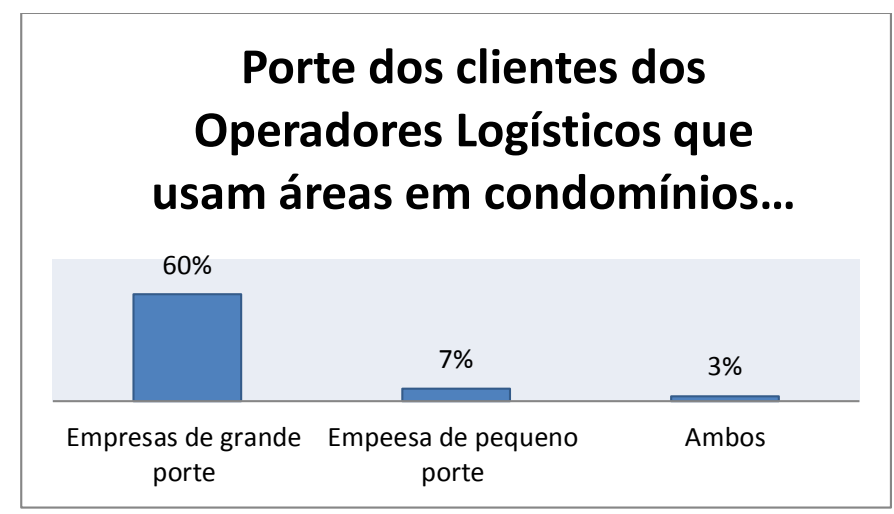

Figura 5 - Porte dos clientes dos prestadores de serviço logístico no Brasil, Fonte ILOS 2013.

Atualmente é comum escutar o termo de CL, já em um país como Estados Unidos, que conta com um mercado muito mais consolidado, usam o conceito de "Business Park" ou seja, parque de negócios, pois segundo "Business Park and Industrial Development Handbook"(2001), oferecem dinamismo, ferramentas de trabalho, tecnologia e desenvolvimento. Já no brasil esse conceito tem se incorporado ao mercado e hoje são oferecidos empreendimentos de grande porte e com atributos de diferenciados.

Exemplos de empresas brasileiras que decidiram investir e / ou se especializar em empreendimentos de CL até 2016 são:

- Bresco

- Prologis CCP

- GR Properties

- GL Properties

- Hines

- VBI Real Estate

- $\quad$ BBP - Brazilian Business Park

- TRX

- LOG Commercial Properties

A seguir, exemplos de projetos que foram desenvolvidos por estas empresas nos últimos anos. 


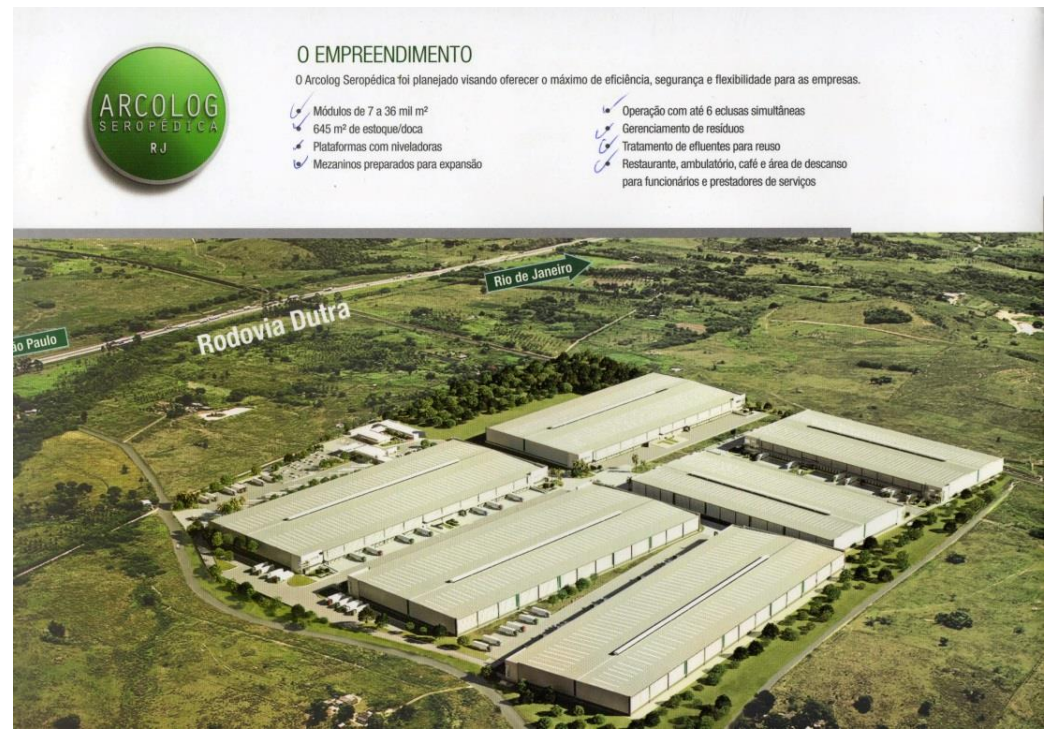

Figura 6 - Ilustração do CL ARCOLOG, localizado em Seropédia, RJ, Rodovia Dutra, km 204, incorporado pela empresa VBI

\section{GLP Campinas \\ GLP}

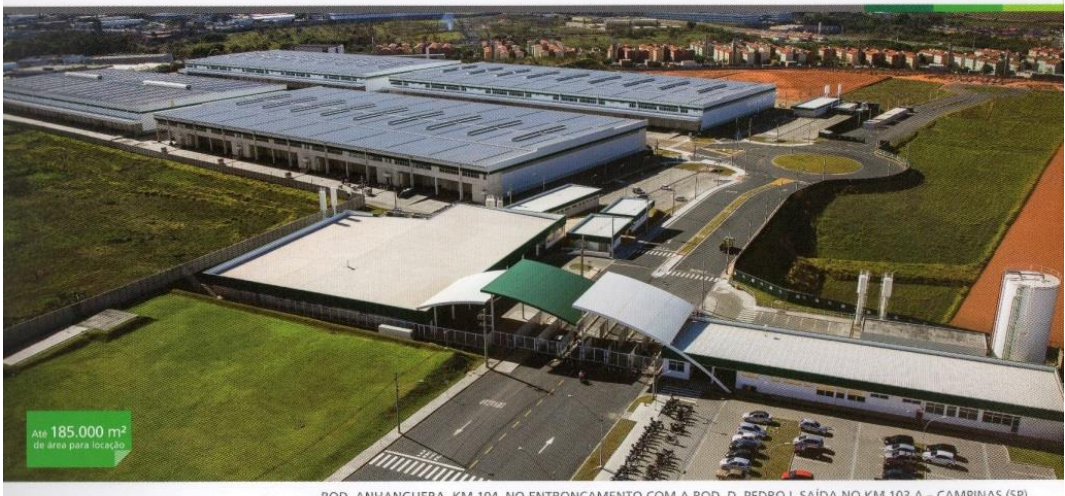

ROD. ANHANGUERA, KM 104, NO ENTRONCAMENTO COM A ROD. D. PEDRO L, SAIDA NO KM 103 A- CAMPINAS (SP)

Figura 7 - Ilustração do CL GLP Campinas, localizado em Campinas, SP, Rodovia Anhanguera, km 104, incorporado pela empresa GLP 


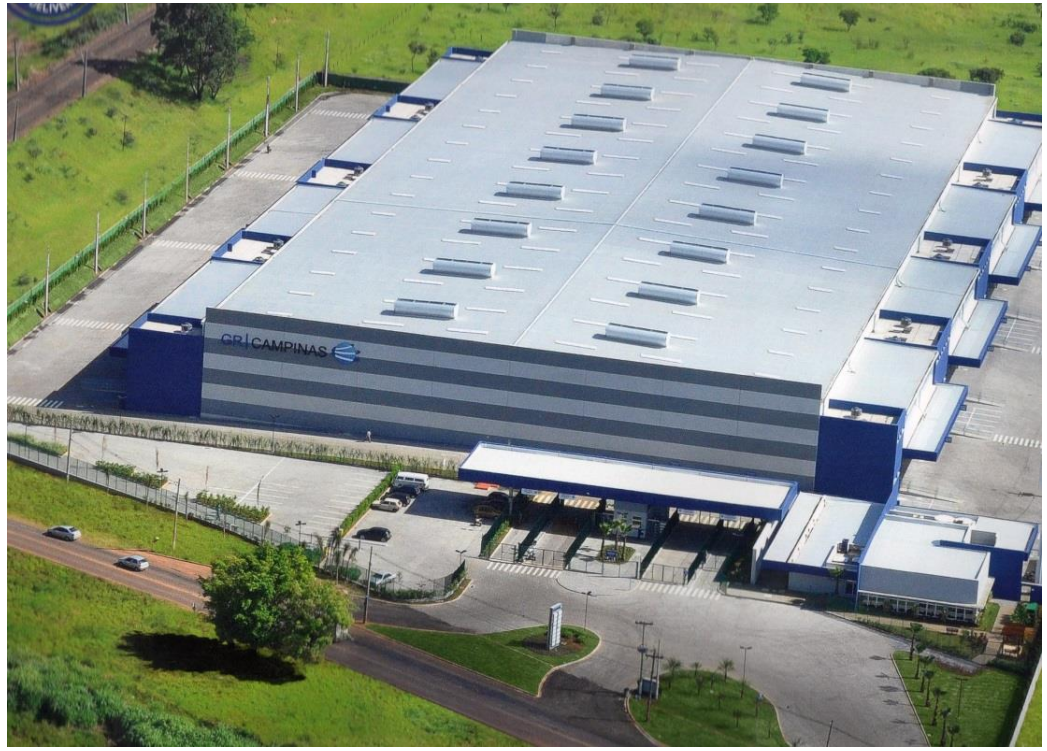

Figura 8 - Ilustração do CL GR Campinas, localizado em Campinas, SP, incorporado pela empresa GR Properties.

\section{GLP Gravataí \\ GLPA}

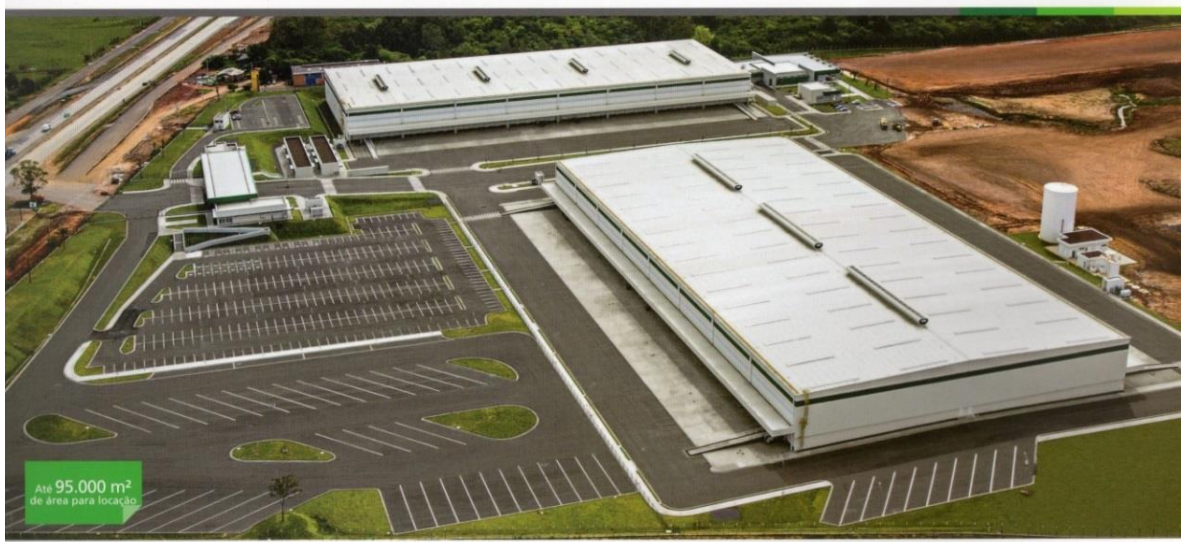

Rod. RS $118, \mathrm{~km} 11$ - próximo à Av. Frederico Augusto Ritter - Gravatai (RS)

Figura 9 - Ilustração do CL GLP Gravataí, localizado em Porto Alegre, RS na ROD. RS-118, $\mathrm{km} \mathrm{11,} \mathrm{incorporado} \mathrm{pela} \mathrm{empresa} \mathrm{GLP}$ 


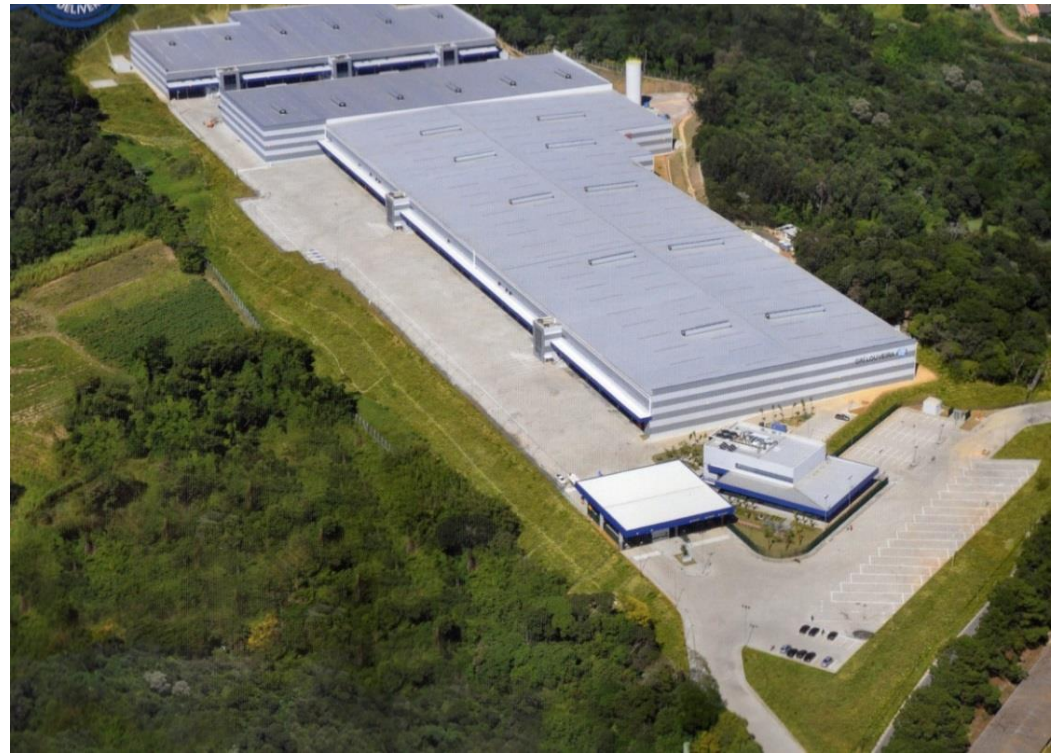

Figura 10 - Ilustração do CL GR Louveira, localizado em Louveira, SP, Rod. Anhanguera km 72 incorporado pela empresa GR Properties.

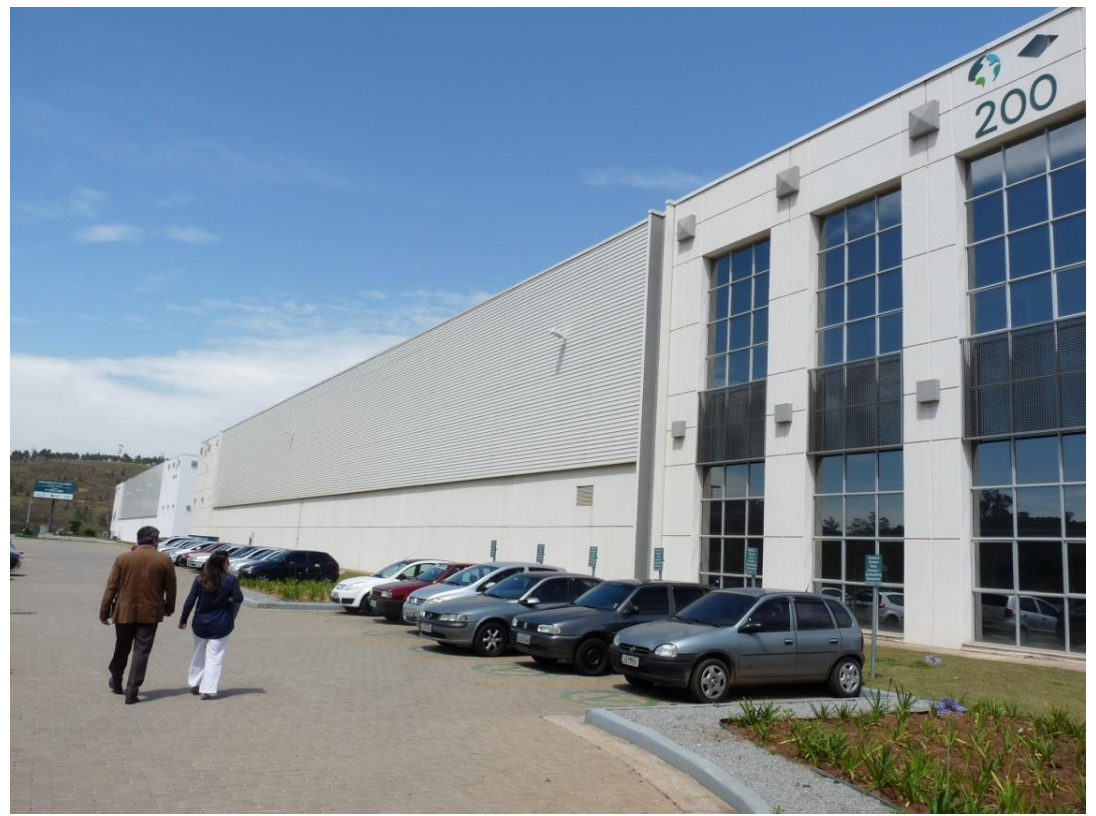

Figura 11 - Fotografia do CL Cajamar Industrial Park, localizado em Louveira, SP, Rod. Anhanguera km 72 incorporado pela empresa Prologis, CCP. 


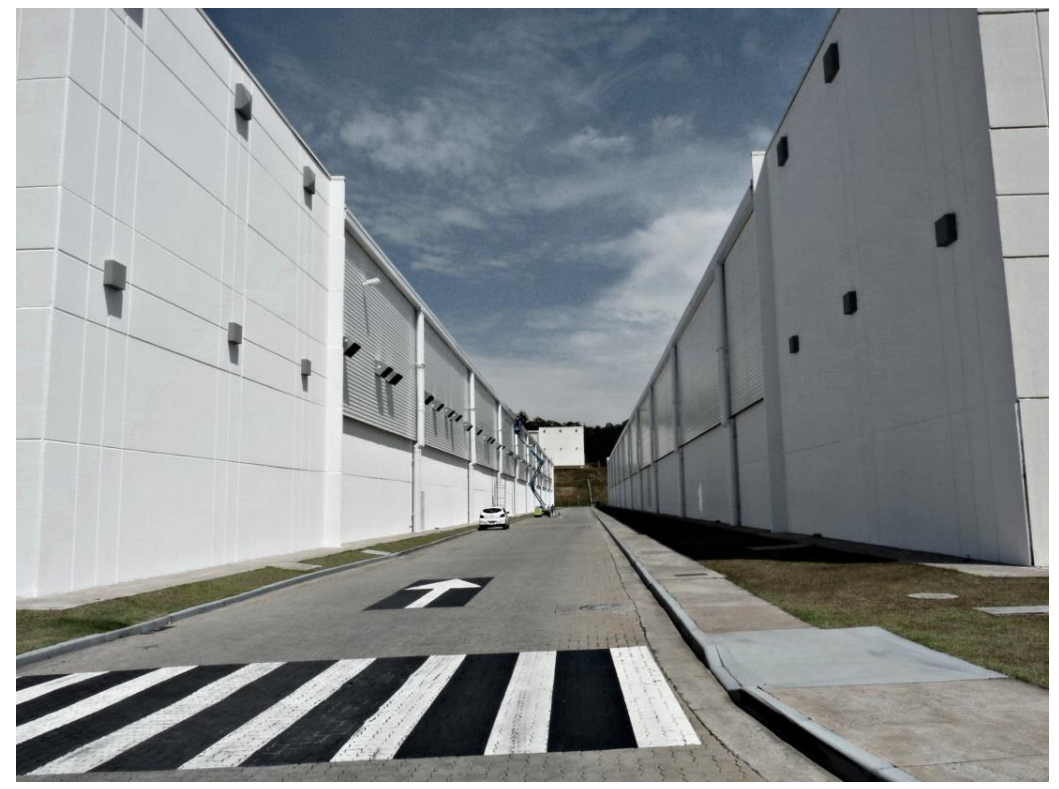

Figura 12 - Fotografia do CL Cajamar Industrial Park, localizado em Louveira, SP, Rod. Anhanguera km 72 incorporado pela empresa Prologis, CCP.

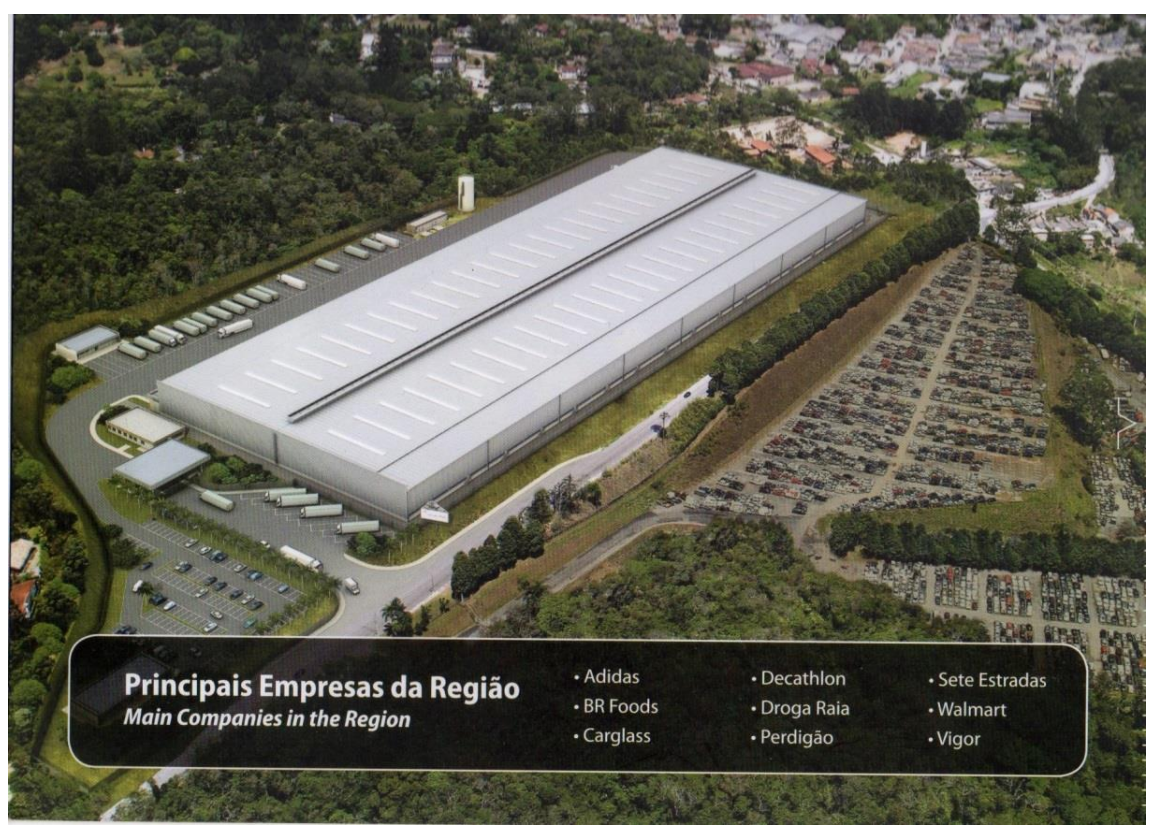

Figura 13 - Ilustração do CL Embu II, localizado em Embu, SP, incorporado pela empresa Hines. 


\subsubsection{Classificações utilizadas no mercado de Condomínios Logísticos}

Os Condomínios Logísticos são empreendimentos oferecidos principalmente para locação, comumente conhecido no mercado de Real Estate como EBI (empreendimentos de base Imobiliária) ${ }^{11}$. A maioria destes empreendimentos são projetados na base especulativa, e tentam satisfazer às necessidades e desejos de diferentes usuários com relação à infraestrutura, serviços, localização e segurança. Oferecem eficiência operacional dentro de áreas moduladas no ambiente interno de um condomínio. O parque corporativo também esta munido de serviços compartilhados com outros usuários.

Dentro da bibliografia consultada, tanto nacional como internacional não foi achado um sistema de certificação da qualidade deste tipo de edificação. As publicações encontradas descrevem características comuns nos CL segundo sua classe, porem não foi achado um sistema de classificação com uma escala definida de valores que permitira avaliar e comparar o total de características oferecidas no mercado. Algumas destas publicações já foram aqui citadas como o caso das classificações da empresa especializada Colliers. Outras publicações internacionais defendem critérios de qualidade dos CL, Sonneman (2001), cita os desafios na avaliação de propriedades "simples" de armazenagem, mas não utiliza uma classificação, Machado (2013) apresenta uma metodologia de avaliação, porem, foca a pesquisa num processo de tomada de decisão. Atualmente vários empreendimentos de CL escolhem conceber o projeto dentro dos parâmetros da certificação LEED, como uma opção de certificação, porem esta certificação é focada em eficiência energética e concepção de um projeto com parâmetros de sustentabilidade, não de eficiência logística.

Desta forma, a classificação de CL no Brasil continua sujeita à arbitragem de empresas de consultoria e de comercialização, e os atributos que são avaliados não indicam uma hierarquia de classificação específica, robusta e imparcial, que ofereça respaldo aos usuários. Este Sistema de classificação enviesado deve ser melhorado e disponibilizado ao setor por meio de um Sistema de Certificação da qualidade, com critérios bem fundamentados no qual se análise o estado dos atributos, sob o ponto de vista do usuário e dos empreendedores consolidados.

\footnotetext{
${ }^{11}$ De acordo com (Rocha Lima Jr., Monetti, and Alencar 2010), considera-se "empreendimento de base imobiliária" aquele destinado a obtenção de renda por exploração ou aluguel, sendo o caso de hotéis, shopping-centers, build-to-suit, entre outros.
} 
Assim, o presente estudo elenca diferenciais dos projetos dentro de uma matriz de atributos, a qual forma parte de um sistema de avaliação que atribui uma pontuação mediante julgamento criterioso e objetivo, enquadrada em certa escala de classificação, no qual se define uma hierarquia dos atributos que concede uma certa classificação do empreendimento, até enquadrá-lo dentro de uma classe que estabeleça uma determinada categoria, consolidada por um comitê de classificação que aprova sua inserção.

A definição de empreendimento logístico como edifício isolado ou como sendo apenas a estrutura física de suporte é muito limitada. Ela foi substituída pelo conceito de condomínio logístico como sendo o ambiente adequado ao desenvolvimento dos negócios e escoamento como parte integrante destes. Deste modo, segundo ILOS, 2013, os principais fatores levam as empresas a optarem por condomínios logísticos em vez de galpões isolados são a localização do condomínio, a infraestrutura oferecida e a segurança, sendo que os prestadores de serviços logísticos que procuram estes condomínios preferem galpões modulares no padrão do empreendimento. Sob este ponto de vista se faz evidente que os empreendimentos de CL precisam acompanhar as evoluções tecnológicas, referentes a materiais construtivos, de conceitos arquitetônicos e de infraestrutura oferecida, bem como uma adequada localização com fácil acesso à rede viária nacional, aeroportos, portos ou ferrovias. 


\section{IMPORTÂNCIA DO SISTEMA DE CLASSIFICAÇÃO DA QUALIDADE DE CONDOMÍNIOS LOGÍSTICOS}

O objetivo geral da pesquisa é desenvolver um Sistema de Certificação da qualidade de CL no Brasil, o qual oferece uma analise dos atributos existentes em um determinado galpão logístico. O Sistema de Classificação identifica e analisa os diferentes atributos que enquadram um empreendimento dentro de uma classe específica, para dar suporte a uma leitura de qualidade dos empreendimentos inseridos no mercado, e assim permitir fazer um juízo de valor baseado na informação transparente da qualidade oferecida num empreendimento.

Adicionalmente, a pesquisa visa apresentar esta certificação dentro dos parâmetros e com apoio do Núcleo de Real Estate da Escola Politécnica da Universidade de São Paulo (NRE/POLI/USP), como garantia de qualidade e imparcialidade a disposição do mercado nacional brasileiro.

O sistema de classificação permite ter uma visão de CL como uma estrutura física de suporte que se ajusta às demandas de diversas classes de usuários. As empresas que despertam interesse para este tipo de empreendimentos precisam garantir a eficiência das características por médio de critérios validados de qualidade, que acompanham as evoluções tecnológicas de materiais construtivos e de estruturas com foco na eficiência do desempenho das gestões de operação. Um certificado de qualidade evidencia a perecibilidade ${ }^{12}$ da qualidade ao longo do tempo, bem como a diversificação oferecida ao mercado com o uso de mais e melhores tecnologias. Assim, os CL que buscam se encaixar em uma classe estratificada, terão a opção de se apresentar segundo sua estratificação ou classe, de maneira dinâmica dentro da sua vida útil. Ao conceituar qualidade de edifícios, seja qual for seu uso, fica evidente a perecibilidade deste conforme transcorre a vida útil do edifício.

Assim por exemplo, dez anos atrás num galpão logístico se oferecia infraestrutura predial muito mais simples se comparado com os últimos lançamentos das empresas especializadas

\footnotetext{
12 Perecibilidade refere-se às características físicas que oferece um edifício e que satisfaz as exigências dos usuários ao longo do tempo. Assim, um certificado de qualidade para CL deve se submeter a revisões periódicas que avaliem ditas características dentro dos padrões exigidos pelo mercado a cada período, e confrontar os edifícios com os avanços tecnológicos ou necessidades surgidas desde a concepção do projeto até a data atual.
} 
do setor, que oferecem edifícios construídos com atributos diferenciais e utilizando tecnologia mais avançada. Atualmente, 2016, os empreendimentos entregues há uma ou duas décadas apresentam certo grau de obsolescência funcional e tecnológica, ainda que tenham passado por renovação nos seus principais sistemas.

Deste modo, quanto mais tempo decorrer entre a construção ou a readequação de um empreendimento, mais provável será a deterioração da sua qualidade, em termos de adequação funcional e tecnológica, como por exemplo, o acabamento e a resistência dos pisos, os sistemas de monitoramento e processamento de dados, a de automação no sistema de iluminação, sistemas de controle e eficiência da eletricidade, e/ou ainda, a qualidade pode ficar comprometida por estar localizado em zona distante ou com difícil acesso à rede viária nacional. Estes fatos de perecibilidade da qualidade tornam evidente a importância de contar com um sistema de Certificação da Qualidade que homologa a inserção do empreendimento dentro de uma classe, por um período determinado.

Por outro lado, é indispensável para o bom planejamento definir a qualidade de cada empreendimento antes de o empreendedor tomar a decisão do investimento, também por este motivo é importante dispor de um Sistema de classificação dos CL que seja imune aos interesses envolvidos nas negociações dos espaços, através de informação clara e objetiva. No momento presente, detecta-se que as classificações utilizadas para fazer referência à qualidade de CL são resultantes de critérios arbitrados por partes interessadas e que comprometem a isenção da avaliação.

Ademais, sem um Sistema de classificação bem fundamentado, o uso de pesquisas de mercado que revelam indicadores tais como índices de vacância, setorização do produto, preço de locação, etc. fica comprometido para suportar adequadamente tanto decisões de investimento por parte de empreendedores quanto dos usuários na escolha dos empreendimentos que os atendam em consonância com as suas necessidades.

A presente pesquisa estrutura um Sistema de Certificação da qualidade de CL que visa endereçar as questões apresentadas, e enumeradas, a seguir, como:

[i] - estratificação do mercado de CL de forma imparcial, sob uma serie de critérios e de maneira unificada para todo o mercado nacional e 
[ii]-o compromisso de periodicamente realizar, uma atualização da classificação hierarquizada, que indica a qualidade dos empreendimentos em questão, como medida para lidar com a perecibilidade da qualidade dos mesmos.

A partir deste estudo, se define uma escala que estabelece uma classificação hierarquizada dos condomínios logísticos, que resulta na emissão de um Certificado de qualidade. Os elementos deste Sistema de Certificação estão definidos nesta pesquisa e tem aplicação direcionada ao mercado nacional de CL, segundo o subitem a seguir, “3.1 Qualidade da pesquisa”.

O presente Sistema de Certificação conserva o processo criado por Veronezi (2004), no qual a criação de um comitê de classificação garante a imparcialidade da classificação emitida para o prédio em análise, motivo pelo qual é conservado como componente do Sistema de classificação, que por sua vez é um subsistema do sistema maior (de Certificação). Assim, a pesar de envolver a opinião da instituição emissora do certificado (não necessariamente a opinião do indivíduo que analisa o galpão), o Sistema de Certificação garante imparcialidade pela inexistência de vínculos ou interesse com relação ao CL em análise (interesse em destacar ou ocultar atributos). Adiciona-se também as características ressaltadas ao inicio da introdução, que explica como o Sistema de classificação foi baseado na opinião prevalente dos participantes (especialistas nesta área do mercado imobiliário), para fortalecer a imparcialidade aqui destacada.

Como mencionado anteriormente, este Sistema de Certificação segue as bases e a estrutura do "Sistema de Certificação da Qualidade de Edifícios de escritórios no Brasil" e por este motivo, a classificação dos condomínios logísticos fica consolidada pelo comitê de classificação que emite um certificado definitivo para a inserção de cada galpão no sistema de classificação segundo a classe na qual encaixa, sempre com o endosso do Núcleo de Real Estate da Escola Politécnica da USP e pelo tempo especificado.

Importante ressaltar que o Sistema de Certificação de qualidade de condomínios logísticos fica disponibilizado para o mercado e assim colaborar na melhora da qualidade das informações existentes e disponibilizadas a respeito de CL no Brasil. Desta maneira, serão diretamente beneficiados os seguintes setores envolvidos:

[i] - usuários: para comparar serviços e localização, respeito aos preços de locação, por exemplo. 
[ii] - empreendedores / investidores: conseguem definir características do produto CL para lançamento, que estabelece os limites do patamar de retorno, entre outros.

[iii] - Projetistas: permite-lhes definir o padrão do empreendimento segundo as expetativas do negocio.

[iv] - órgãos controladores: tais como, Comissão de Valores Mobiliários, para estudar a aprovação de um empreendimento de CL vinculados à securitização.

\subsection{Qualidade da pesquisa.}

Segundo a revista Buildings (2015), a respeito ao Panorama do setor de galpões logísticos, “O foco na qualidade tem sido uma conduta das empresas do setor, pois ainda existe uma demanda reprimida bastante significativa e os galpões Classe A, com diferencias, ainda valem o investimento", ou seja, que existe una influência dos atributos dos CL na escolha dos usuários. Estes usuários procuram um local onde, além da armazenagem, existam outros serviços tais como localização privilegiada, infraestrutura física diferenciada, maior segurança patrimonial, incentivos fiscais e facilidade de adequação da operação, tal como mostrado na secção 2.1.2 Comportamento Setorial.

Esta pesquisa origina um Sistema de Certificação de Condomínios Logísticos que represente uma ferramenta de avaliação com critérios robustos e imparciais para definir a qualidade do produto e enquadra-lo em uma classe a partir de seus atributos.

Baseando-se nesta ideia e tomando como ponto de partida o Sistema de certificação da qualidade de escritórios no Brasil, oferecido pelo Núcleo de Real Estate (NRE) da escola Politécnica da Universidade de São Paulo, no qual, Veronezi (2004), estabelece como imprescindível para a tomada de decisões que:

a qualidade de cada edifício de escritórios esteja bem definida, através de sua classificação hierarquizada, e que esta informação coincida, sem ruído, para todos os envolvidos ou afetados pela questão em discussão, e não em situações onde as classificações utilizadas para fazer referência à qualidade de edifícios de escritórios fossem resultado de julgamentos casuais e particulares das empresas/indivíduos envolvidos com o edifício em análise. A ausência de critérios a serem seguidos para emissão de tais classificações predomina e quando esses critérios existem, além de superficiais e pobres, são singulares para cada empresa atuante nesse mercado. Assim, a classificação resultante é função do interesse de seu emissor com relação ao edifício (interesse em exaltá-lo ou ofuscá-lo). 
Desta forma e ao se fazer uma analogia prudente e respectiva diante do mercado de CL, adota-se e adapta-se a afirmação da objetividade imparcial que logra gerar um Sistema de Certificação da qualidade em contrapartida aos critérios particulares o de conveniência temporal apresentados na Introdução.

Portanto, segundo o estabelecido por Veronezi (2004, p. 18), o grau de qualidade adjudicado para um edifício deve estar ligado a uma classificação hierarquizada dentro de um sistema. Este sistema poderia conferir uma avaliação própria, única e válida na data especificada.

Qualidade definida através de classificação hierarquizada transforma-se em uma ferramenta que esquematiza a informação para que coincida de maneira adequada, para todos os envolvidos ou afetados pela questão. Um sistema de classificação a disposição do mercado de CL significa oferecer um método científico que defina de maneira imparcial a classe onde será enquadrado o empreendimento.

Os galpões são edifícios de formato simples, porém os empreendimentos de CL oferecem uma série de serviços básicos e diferenciados que podem ser classificados desde o ponto de vista do usuário. Por tanto, existe no mercado uma variedade de CL para atender as necessidades dos diversos usuários. A variedade dos serviços oferecidos origina uma segmentação ou diferenciação entre os empreendimentos que pode ser classificada. Conforme a revista Biuldings (2014 apud Monetti 2014), a classificação de empreendimentos comerciais no Brasil é absolutamente necessária, pois outorga transparência aos interessados.

\footnotetext{
Acho a classificação absolutamente necessária. No fundo trata-se de uma segmentação útil, pois significa transparência, seja para o projetista - que precisa conhecer os atributos ou as características que tem que embarcar nas edificações para o pleno atendimento das demandas de quem vai se servir do edifício -, seja para o usuário - para que ele tenha uma base de comparação entre os diferentes empreendimentos onde há espaço disponível para alugar, com diferentes preços. Existe, ainda, o próprio empreendedor, para o qual as informações são importantes na hora em que ele desenha um empreendimento focado em um determinado público alvo. A classificação cumpre exatamente a função de dar transparência para essas adequações.
}

\subsection{A certificação como parte desta pesquisa.}

O Sistema de Certificação estruturado nesta pesquisa leva em consideração atributos dos CL que podem ser considerados básicos até outros que poderiam ser classificados como diferencias, pois a ideia é avaliar a funcionalidade do produto além das características que 
melhoram sua eficiência ou aparência, pois além da aderência do empreendimento ao mercado, trata-se de verificar padrões mínimos estabelecidos por normalização. Porem, nem todos os atributos normalizados para CL estão incluídos na matriz de atributos, pois esse não é o objetivo deste sistema de certificação. Os atributos que formam parte da matriz, mas que não são exigências normativas ${ }^{13}$ de construção o funcionamento do condomínio logístico foram adicionadas por ser sinalizadas como parte importante do empreendimento, segundo alguns dos participantes (PMCLB). Inicialmente, se tomou como base da matriz os atributos sugeridos na pesquisa tomada como referência, porem foram descartados todos os que não encaixavam com o produto CL, logo foram acrescentados atributos derivados da pesquisa bibliográfica, das visitas técnicas a uma serie de CL e sugestões de usuários e / ou participantes. Atributos não normalizados podem acrescentar eficiência ao projeto, fora disso, as normas obedecem a padrões mínimos que podem ser extrapolados para atender as necessidades dos usuários, a exemplo, um heliponto não é uma exigência normativa, mas é altamente valorizado por alguns usuários.

Cada projeto define seus próprios padrões, estes padrões delimitam patamares de qualidade que podem ser mínimos ou maximizados de acordo ao total de atributos oferecidos.

Quanto à aplicação do questionário baseado na matriz de atributos, foi especificamente destacado que todos os participantes (empreendedores, projetistas, investidores e usuários) deveriam se posicionar como usuários, pois os patamares de qualidade são definidos sob o ponto de vista do usuário de CL. Neste Sistema de Certificação a qualidade dos CL esta referenciada ao ponto de vista dos ocupantes (usuários).

\footnotetext{
13 As normas de funcionamento de qualquer edifício ou condomínio não abrangem a totalidade dos atributos de um projeto, dada a subjetividade da qualidade do produto tratada sob o ponto de vista do usuário.
} 


\section{MÉTODO DE DESENVOLVIMENTO DO SISTEMA DE CLASSIFICAÇÃO.}

Retomando a estrutura descrita no capítulo "1. INTRODUÇÃO", o desenvolvimento deste Sistema de Certificação de qualidade de condomínios logísticos foi da seguinte maneira:

pesquisa bibliográfica;

entrevistas aos especialistas, participantes do mercado de condomínios logísticos no Brasil-PMCLB's;

visitas a CL do segmento enfocado;

observações realizadas no mercado de CL do Brasil;

arbitragens iniciais, seguidas de testes de validação e calibragem entremeados com sucessivos ajustes.

O ponto de partida foi notar o acelerado crescimento do mercado de CL junto com muitas informações dispersas que estabeleceram um rico material de pesquisa, até chegar aos referenciais da qualidade deste tipo de empreendimento, conjunto de informações que ressaltou a necessidade de um robusto e imparcial sistema de certificação que se inicia com a concepção de um Sistema de Classificação, este último é apresentado a seguir como um subsistema do Certificado da Qualidade.

O sistema de classificação, é conformado por:

- matriz de atributos;

- escala de classificação; e

-comitê de classificação.

$\mathrm{O}$ esquema anterior de itens permite estabelecer regras para emitir o certificado de qualidade para um galpão integrante de um CL específico.

Em seguida, se apresentam os parâmetros utilizados para arbitrar uma matriz de atributos inicial que foi apresentada para os PMCLB's selecionados.

A partir da matriz de atributos inicial e com ajuda da técnica de pesquisa selecionada, foi possível chegar na matriz de atributos definitiva, utilizada para construir as tabelas de avaliação da certificação da qualidade. 
É válido reiterar que a presente pesquisa esta espelhada no "Sistema de Certificação da Qualidade de Edifícios de escritórios no Brasil" Veronezi, 2004, o qual é reconhecido e aceitado pelo mercado de real desde sua publicação ate a data atual, primeiro semestre de 2016, pelo NRE/POLI/USP. Por tanto e considerando a boa aceitação deste último perante o mercado alvo, se tomou a decisão de utilizar a mesma metodologia e bases regulamentares já estabelecidas nele.

Desta maneira, segundo Veronezi (2004), os prazos para verificação da validade deste tipo de certificado assim como a atualização do sistema de classificação e as intervenções necessárias para esta atualização, foram definidos a partir de observações e estudos sobre o mercado utilizando empreendimentos presentes no mercado e sua evolução histórica. O tempo estabelecido e testado esta fixado em três (3) anos.

O presente sistema de classificação utiliza dados de comportamento do mercado de CL, assim como a opinião dos especialistas deste mesmo mercado. Por este motivo se dedica o presente capitulo para o detalhamento da sua estruturação.

Importante assinalar que as opiniões prevalentes no meio especializado foram a base da arbitragem inicial, após revisão bibliográfica e de mercado. O processo Delphi, combinado com técnicas da Estatística Descritiva, permite detectar as opiniões dos PMCLB e chegar num fator de importância para cada atributo. Estas ferramentas estão detalhadas neste capítulo 4.

O sistema de classificação foi elaborado a partir de três etapas que serão explicadas a seguir:

i) arbitragem da matriz de atributos;

ii) arbitragem da escala de classificação; e

iii) validação e calibragem do sistema de classificação (matriz de atributos e escala de classificação).

\subsection{Arbitragem da matriz inicial de atributos}

Tendo conhecimento do "Sistema de Certificação da Qualidade de Edifícios de escritórios no

Brasil", Veronezi, 2004, do sucesso da metodologia empregada e da disseminação do uso do sistema no mercado brasileiro, foram adotadas as mesmas premissa de estruturação daquele sistema para construir o ora proposto nesta Dissertação. Assim, inicialmente percebeu-se que 
vários grupos de atributos, como por exemplo, sistema elétrico, hidráulico, detecção e combata a incêndio, segurança patrimonial, etc, da matriz de Veronezi (2004) poderiam também compor a nova matriz e posteriormente serem avaliados pelos especialistas PMCLBs.

A seguir foi selecionado o procedimento para melhorar essa arbitragem inicial da matriz do presente Sistema de Certificação de qualidade:

identificação da opinião prevalente no mercado, de acordo com a visão de especialistas do mercado e do que se verifica embarcado nos condomínios logísticos, além de levantamento bibliográfico e publicações especializadas neste mercado;

adoção da técnica Delphi, como método de coleta da opinião dos especialistas

PMCLB, conforme preconizado em Veronezi (2004);

Seleção dos participantes, dentro dos parâmetros do processo Delphi (mínimo 10 e máximo 50);

entrevistas com os participantes selecionados, para definir seu interesse em participar da pesquisa e sua opinião dos atributos já arbitrados e sobre os atributos que, no seu critério, deviam ser incluídosna matriz;

visitas técnicas, para observar de perto os atributos oferecidos nos empreendimentos de CL consolidados do mercado e confrontar os critérios de qualidade.

modelagem da matriz inicial.

\subsubsection{Identificação da opinião prevalente no mercado}

A qualidade do produto oferecido por um empreendedor sempre estará relacionada à aderência de seus atributos a um certo referencial de qualidade. Segundo Rocha Lima Jr. (1993), este referencial compreende um conjunto de atributos do produto e o estado desejável deste conjunto de atributos, segundo o que se identifica como opinião prevalente de mercado. Portanto, pode ser construída um sistema de qualificação sob o ponto de vista do usuário de CL, desde que seja possível fazer um enquadramento do empreendimento dentro de um padrão desde o ponto de vista do usuário e segundo um referencial de qualidade.

A qualidade tem uma subjetividade intrínseca que pode ser explorada dentro de um sistema de classificação para justificar sua restrição ao mercado brasileiro (Veronezi, 2004), o que 
significa avaliar o desempenho de um CL, sob o ponto de vista do usuário, sem deixar de lado a relação existente com aspectos, políticos, tecnológicos, econômicos, legais e climáticos, entre outros que são particulares a cada país.

Ao classificar os empreendimentos de CL, especialistas do mercado apresentam características e valores considerados como atributos de projetos de alta qualidade. A seguir se destaca algumas de essas publicações.

O instituto ILOS (2013) realizou uma pesquisa de mercado onde foram ouvidos sessenta dos principais operadores logísticos do Brasil, usuários e não usuários de CL (gráfico 4.1 e 4.2). Conforme os dados levantados na pesquisa, seis são os fatores principais e determinantes para a escolhia de um CL:

A localização.

A infraestrutura física oferecida no condomínio

Maior segurança patrimonial

Os serviços oferecidos

Incentivos fiscais

Facilidade de adaptar as instalações existentes a operação

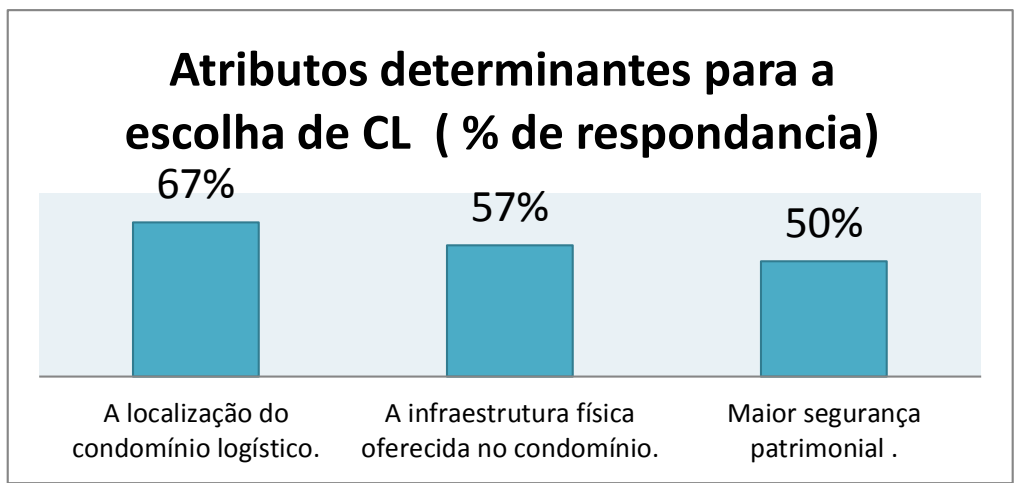

Figura 14 - Atributos determinantes para a escolha de CL (\% de respondencia ${ }^{14}$ ) Elaborado pelo autor, ILOS 2013.

\footnotetext{
$14 \%$ de respondencia, se refere ao grupo de participantes que marcaram as opções apresentadas como importantes ou determinantes na hora de selecionar um CL.
} 


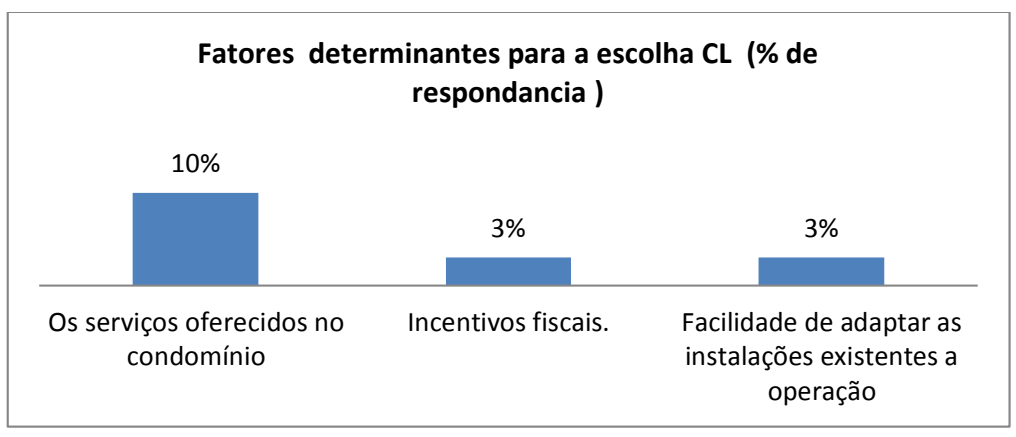

Figura 15 - Fatores determinantes para a escolha CL (\% de respondencia), elaborado pelo autor conforme ILOS 2013.

Os parâmetros de qualidade destacados anteriormente podem ser complementados com a pesquisa de Poletto (2011), na qual, são destacados alguns itens prioritários do ponto de vista do usuário, que segundo ele, trazem benefícios operacionais, uma maior competitividade e aumento da demanda dos imóveis, estas características citadas são:

pé direito entre 10 a 12 metros de altura, que reduz o custo de locação por $\mathrm{m}^{2}$, pois admite a verticalização da área de armazenagem (metragem cúbica);

docas para cada $800 \mathrm{~m}^{2}$, ou até $500 \mathrm{~m}^{2}$ de área de armazenagem, incluído toda a infraestrutura ligada a este item, como por exemplo, a instalação de sistema de niveladores;

piso com alta capacidade de resistência, apropriado para a verticalização do estoque sem o desgaste em função do peso; além de ser construído com tecnologia de nivelamento a laser, que, aliás, oferece um menor desgaste das rodas de empilhadeiras elétricas ou a gás. Inclusive, o piso protendido oferece benefícios de manutenção das empilhadeiras ao operador - quando não existe junta entre blocos, o que na opinião do autor de traduz em diferenciação competitiva;

> instalação de sprinklers - sistema de combate a incêndio -, os quais permitem armazenar uma maior variedade de produtos - no caso de inflamáveis ou documentos preenchem as exigências do corpo de bombeiros na maioria dos municípios dependendo do tamanho da área coberta e ajudam na redução no custo da contratação de seguro;

Segurança - itens que incrementam a segurança patrimonial favorecem a demanda, e até mesmo com produtos de valores agregados mais altos (que conseguem viabilizar um custo de locação mais atrativo para o investidor), dentro dos quais estão: portaria blindada, controle de acesso com garras de gato (fura-pneu para bloqueio de caminhões), sistema CFTV 
(circuito fechado de câmeras com monitoramento permanente), sistemas de alarme, sensores de presença, controle de acesso eletrônico, etc.

De outro lado, segundo a revista Buildings, 2012, após coletar características presentes em cento e sessenta e quatro (164) condomínios logísticos prontos para ocupação, as principais e fundamentais características técnicas deste tipo de empreendimento observadas pelos usuários são:

Altura do pé-direito,

Capacidade de resistência do piso,

$>$ Qualidade de docas,

Existência de plano cross-docking (docas de pelo menos duas laterais do galpão),

$>$ Pátio de manobras,

Existência de estacionamento para caminhões,

Utilização de Sprinklers.

Machado (2013) estabelece características utilizadas para apontar a qualidade de CL, as quais são descritas na Tabela 4 a seguir.

No mesmo trabalho, Machado (2013), apresenta uma metodologia de avaliação de CL na região metropolitana de São Paulo onde:

Apresenta-se as classes A, B e C, de acordo com as características do empreendimento de CL. Porem, essas características apresentadas como critérios de avaliação do empreendimento são limitados dentro das divisas do lote de implantação desconsiderando critérios importantes como a localização e vias de acesso.

Algumas empresas atuantes no setor de CL adotam tipologias e classificam os empreendimentos segundo características apresentadas como qualidade e aplicadas atualmente no mercado, como mostrado no capítulo “1INTRODUÇÃO” tabelas 1, 2 e 3

Desta forma, algumas empresas utilizam critérios de qualidade como os apresentados no Seminário Centros de Distribuição E Condomínios Logísticos (2011) em São Paulo (ver Tabela5). 
Nesta Tabela 5 a seguir, coincide a maioria dos atributos identificados no mercado como referencial de qualidade e que estabelecem uma tipologia assumida.

\begin{tabular}{|c|c|c|c|c|}
\hline & $\begin{array}{l}\text { Pé } \\
\text { Direito }\end{array}$ & $\begin{array}{l}\text { Capacidade de } \\
\text { sobrecarga do } \\
\text { piso }\end{array}$ & Sistemas construtivos & $\begin{array}{l}\text { Área de } \\
\text { Estacionamentos }\end{array}$ \\
\hline 1 & $\begin{array}{l}6 \mathrm{~m} \quad \mathrm{a} \\
8 \mathrm{~m}\end{array}$ & $\begin{array}{l}<4 \mathrm{tf} / \mathrm{m}^{2} \text { ou } \\
\text { Desconhecida }\end{array}$ & $\begin{array}{l}\text { Telhado de cimento } \\
\text { amianto Insuficiente }\end{array}$ & Insuficiente \\
\hline 2 & $10 \mathrm{~m}$ & $\begin{array}{l}\text { Entre } 4 \mathrm{tf} / \mathrm{m}^{2} \mathrm{e} \\
5 \mathrm{tf} / \mathrm{m}^{2}\end{array}$ & $\begin{array}{l}\text { Estrutura e cobertura pré } \\
\text { fabricada em concreto }\end{array}$ & Insuficiente \\
\hline \multirow[t]{3}{*}{3} & \multirow[t]{3}{*}{$12 \mathrm{~m}$} & \multirow[t]{3}{*}{$\begin{array}{l}\text { Superior a } \\
5 \mathrm{tf} / \mathrm{m}^{2}\end{array}$} & $\begin{array}{l}\text { Estrutura e cobertura pré } \\
\text { fabricada concreto }\end{array}$ & \multirow[t]{3}{*}{ Adequadas } \\
\hline & & & $\mathrm{Ou}$ & \\
\hline & & & $\begin{array}{l}\begin{array}{l}\text { Estrutura pré-fabricada } \\
\text { em }\end{array} \\
\begin{array}{l}\text { concreto } \\
\text { fechamentos e }\end{array} \\
\begin{array}{l}\text { cobertura em } \\
\text { metálicas }\end{array}\end{array}$ & \\
\hline
\end{tabular}

Tabela 4 - Tipologias de Condomínios Logísticos Fonte: T. F. Machado, 2013, Dissertação de Mestrado. 


\begin{tabular}{|l|l|}
\hline \multicolumn{1}{|c|}{ Critérios } & \multicolumn{1}{|c|}{ Parâmetro } \\
\hline Pé direito & $10 \mathrm{~m}$ - $12 \mathrm{~m}$ livres \\
\hline Resistencia do piso & Nivelado a laser, acima de $5 \mathrm{tf} / \mathrm{m}^{2}$, podendo ser protendido. \\
\hline Modulação & Acima de 20-23m \\
\hline Estrutura & Concreto pré-moldado ou metálica \\
\hline Fechemento & Placas de concreto ou metálica com alvenaria \\
\hline Incêndio & Sprinklers (J4) e detectores de fumaça \\
\hline Docas & $\begin{array}{l}\text { Em grande quantidade, elevadas, com nivelador, cobertas, pelo menos um } \\
\text { plano de cross-docking. Razão: 1 doca/500m } \text { (mínimo) }\end{array}$ \\
\hline Cobertura & $\begin{array}{l}\text { Cobertura com estrutura metálica, isolamento térmico, domos para iluminação } \\
\text { e ventilação natural. }\end{array}$ \\
\hline Escritórios & $\begin{array}{l}\text { Média 5\% da área de armazenagem,variável pela tipologia do } \\
\text { empreendimento. Bom padrão, com previsão para ar condicionado. }\end{array}$ \\
\hline Segurança & $\begin{array}{l}\text { Total, periférica, interna CFT }, \text { controle de acesso por sistema, ronda e } \\
\text { portaria 24 horas. }\end{array}$ \\
\hline Outros & $\begin{array}{l}\text { Pátio de manobras, vaga para carretas, vagas para auto, infraestrutura de } \\
\text { serviços e apoio aos motoristas, gerador com capacidade para atender 100\% } \\
\text { dos CDs, portaria blindada. }\end{array}$ \\
\hline Vagas de Cerretas & Pelo menos 1 vaga para cada 1.000m² de armazenagem. \\
\hline Prejeto & Concebido conforme necessidades do mercado local, com base no fluxo da região. \\
\hline
\end{tabular}

Tabela 5 - Critérios de avaliação de condomínios logísticos

Fonte: Echeverry (2011b)

Conforme (Sonneman, 2001) os galpões para armazenagem são "simples", tipo caixas. No entanto, um número de características do armazém pode apresentar desafios durante o processo de avaliação. Na apreciação destes armazéns "simples", é essencial considerar cuidadosamente os seguintes fatores para sua comparação:

Extensão do terreno.

Altura de treliça.

$>$ Porcentagem da área de escritório

Instalações de carga

As larguras para manobra de caminhões.

Espessura do pavimento / capacidade de carga.

O serviço de energia

> Relação entre área do terreno e área do edifício.

Tamanho em relação ao tamanho típico edifício.

Declive da rota de acesso ao site.

O conjunto de estudos, informações e tipologias complementam a arbitragem do conjunto de atributos que estruturo a Matriz inicial, a qual foi colocada dentro de um questionário fechado 
que constituí a primeira rodada de pesquisa do mercado, tal como se explica na seção 4.1.5 Modelagem da Matriz Inicial.

\subsubsection{Adoção da técnica Delphi}

O mercado oferece critérios e características, porém o objetivo nesta pesquisa foi detectar as opiniões prevalentes sobre quais atributos presentes em CL deveriam compor a matriz de atributos e qual a importância de cada atributo componente em relação aos demais. Ao aplicar a técnica Delphi com a sequência de duas rodadas de questionários enviados aos PMCLBs conduziu a esse objetivo. A estrutura da metodologia Delphi particular a este estudo está explicada no capítulo 5 “Seleção Da Técnica Delphi”.

O conjunto de atributos para conformar a matriz era um dos resultados almejados com a aplicação da técnica Delphi aos participantes. No entanto, o processo Delphi estabelece que se deve começar já com um questionário prévio estruturado, para simplificar a aplicação para o coordenador e os respondentes, diminuindo o consumo de tempo, e para facilitar a aderência dos resultados ao estudo proposto. Daí a necessidade de uma fase preparatória.

No questionário enviado na primeira rodada, a primeira pergunta, elaborada para cada atributo, era se o mesmo deveria ou não pertencer à matriz de atributos, isto é, se ele era ou não relevante para classificar um CL ou galpão, quanto ao seu desempenho, sob o ponto de vista do usuário.

Assim, segundo Veronezi (2004):

Cada uma dessas respostas, que só podia assumir os valores SIM ou NÃO, era uma variável qualitativa.

O fator de importância relativa de cada atributo constituía uma variável quantitativa. Caso o participante acrescentasse um ou mais atributos à lista recebida, ele devia opinar sobre sua importância relativa seguindo as mesmas regras.

As respostas do primeiro questionário serão analisadas e tratadas através do cálculo da frequência relativa, no caso das variáveis qualitativas (atributo deveria ou não pertencer à matriz) e da moda e da dispersão em relação à moda, no caso das variáveis quantitativas (fator de importância relativa de cada atributo).

Essas estatísticas constituíram o feedback enviado aos participantes junto com o segundo questionário.

Para maior entendimento das anteriores afirmações foi agregado o Apêndice A, que contem o Cap 4.1.2 de Veronezi (2004), onde se explica a estruturação do questionário; além do Apêndice B que contem a Matriz inicial de atributos aderida ao questionário da primeira rodada do presente trabalho. 
A maneira como se estruturou o segundo questionário desta pesquisa, segue a mesma logica empregada por Veronezi (2004), onde conforme Apêndice A foram inseridas 4 colunas referentes à primeira rodada do processo Delphi e uma coluna para a retificação ou alteração da resposta. A figura 4.1 mostra esta estrutura do questionário da segunda rodada da presente pesquisa para ajudar no entendimento.

\begin{tabular}{|c|c|c|c|c|c|}
\hline \multirow{5}{*}{ Atributos Associados ao Galpão } & \multicolumn{3}{|c|}{ ANALISE RESPOSTAS RODADA 1} & \multicolumn{2}{|c|}{ SUA RESPOSTA } \\
\hline & Pertinência & \multirow{4}{*}{\multicolumn{2}{|c|}{\begin{tabular}{|c|c}
\multicolumn{2}{|c|}{ Fator de importância relativa } \\
Opinião & \\
prevalente & Intervalo \\
(entre & ajustado de \\
respondente & dispersão em \\
s que & relação a \\
consideram & opinião \\
prevalente
\end{tabular}}} & \multirow{2}{*}{\multicolumn{2}{|c|}{$\begin{array}{c}\text { FATOR DE } \\
\text { IMPORTÂNCIA } \\
\text { RELATIVA }\end{array}$}} \\
\hline & \multirow{3}{*}{\begin{tabular}{|c|}
$\%$ \\
respondentes \\
que considera \\
atributo \\
relevante p/ \\
classificar o CL
\end{tabular}} & & & & \\
\hline & & & & & \\
\hline & & & & Rodada 1 & Rodada 2 \\
\hline \multicolumn{6}{|l|}{ 1. Sistema Elétrico do Galpão } \\
\hline Disposição de Infraestrutura elétrica na área de Armazenagem & $100 \%$ & 100 & 50 a 100 & 80 & \\
\hline $\begin{array}{l}\text { Medidores individualizados de consumo de energia por módulo } \\
\text { (Possibilidade de Flexibilizar o sistema de alimentação elétrica para módulos } \\
\text { que compõem o galpão.) }\end{array}$ & $97 \%$ & 100 & 70 a 100 & 80 & \\
\hline Infraestrutura para opção de transformador elétrico independente por módulo & $90 \%$ & 90 & 50 a 100 & 80 & \\
\hline Barramentos blindados para área de escritórios & $57 \%$ & 70 & 20 a 100 & 20 & \\
\hline Proteção magnética & $53 \%$ & 50 & 10 a 90 & 20 & \\
\hline
\end{tabular}

FIGURA 4-1 Estrutura do segundo questionário desse processo Delphi.

Tal como exposto por Veronezi, 2004, “Este segundo questionário sofreu algumas alterações em relação ao primeiro”, estas alterações se encontram descritas no Apêndice A.

\subsubsection{Seleção dos participantes}

Esta seleção foi feita considerando obter a opinião de especialistas do mercado de CL do Brasil. Assim foram selecionados 38 profissionais entre arquitetos, projetistas, empreendedores, incorporadores, administradores, usuários, consultores, analistas e investidores de condomínios logísticos no Brasil, os quais conformariam a amostra de PMCLB's empregada neste estudo ou o painel Delphi. A primeira rodada de questionários contou com a participação de 30 respondentes, dos 38 profissionais previamente selecionados. Na segunda rodada de questionários foi possível contar com 25 dos 30 participantes iniciais, visto que 5 mudaram de endereço ou emprego. O segundo questionário foi enviado para estes 25 PMCLBs e foram obtidas 16 respostas diretas, o que significa que aproximadamente $53 \%$ dos respondentes foram mantidos durante todo o processo Delphi. As outras nove respostas foram obtidas de modo indireto, pois se considerou que as respostas da primeira rodada quando não alteradas na segunda se mantinham intactas. 


\subsubsection{Entrevistas com os participantes selecionados}

Antes de aplicar a primeira rodada foi feita uma serie de entrevistas com diferentes PMCLBs, com o objetivo de reconhecer o interesse existente no tema da pesquisa e para consultar o que cada um tinha como parâmetros de qualidade em CL e sobre os atributos que eles consideravam essenciais para este tipo de projeto.

As entrevistas, além de enriquecerem o questionário inicial da técnica Delphi, constituíram uma das formas de divulgação do conteúdo da pesquisa, o que despertou interesse do setor imobiliário abordado. Os entrevistados manifestavam seu interesse em contribuir com a pesquisa nesse sentido, concordaram em participar do processo Delphi e viabilizaram contatos com sua carteira de clientes ou usuários, que, por sua vez, também se prontificaram a formar parte do grupo de participantes da pesquisa dentro do processo Delphi.

\subsubsection{Modelagem matriz inicial.}

Conforme exposto nos capítulos anteriores, o modelo desta pesquisa é o "Sistema de Certificação da Qualidade de Edifícios de escritórios no Brasil", por este motivo foram adotados os mesmos métodos de pesquisa e normativas ali descritos.

A modelagem da matriz inicial da presente pesquisa foi feita de idêntica maneira a do seu modelo, por este motivo, a continuação são inseridas várias trechos textuais deste modelo.

Assim, conforme Veronezi (2004), "quando se trata a arbitragem inicial da matriz de atributos é a arbitragem inicial do preenchimento das colunas "Atributo" e "Fator de importância relativa" que está sendo tratada".

A estrutura da matriz esta explicada no item "6.1.1.1 Estrutura da matriz de atributos" e exemplificada nas figuras $17 \mathrm{e} 18$.

A matriz de atributos, que forma parte do sistema de classificação, será estruturada a partir da opinião prevalente de usuários e atuantes do mercado de Condomínios Logísticos. Aqui a técnica Delphi será empregada para obter uma hierarquia para cada atributo e para reduzir a variação de opiniões entre os envolvidos neste trabalho.

A modelagem da matriz do sistema de certificação da qualidade de CL no Brasil esta espelhada na "estrutura da matriz de atributos" utilizada por Veronezi (2004), quem descreve; 


\begin{abstract}
a matriz de atributos é constituída pelas seguintes colunas: "Particularidade", "Atributo", "Fator de importância relativa", "Pontuação para o edifício" e "Atributo pontuado e ponderado". Estas duas últimas colunas são preenchidas somente por ocasião de avaliação de determinado edifício(galpão), enquanto as colunas "Particularidade", "Atributo" e "Fator de importância relativa" são fixas independentemente do edifício (galpão) em análise.
\end{abstract}

O preenchimento de cada coluna será feito na mesma maneira exposta por Veronezi (2004), por este motivo foi agregado o Apêndice C, que descreve esta situação.

Neste estudo a opinião prevalente buscada no mercado brasileiro de condomínios logísticos será a respeito de quais atributos deverão compor a matriz e qual a escala de importância de cada um deles em relação aos demais, com o fim de atingir uma classificação por classe.

Veronezi, 2004, explica:

O tratamento das respostas dadas pelos participantes na segunda e última etapa de aplicação do Delphi foi usado, entre outros recursos, para arbitrar inicialmente esta matriz.

As estatísticas que balizaram a arbitragem dessa matriz foram frequência relativa das variáveis qualitativas (atributo deveria ou não pertencer à matriz) e moda das variáveis quantitativas (fator de importância relativa de cada atributo), calculadas sobre as respostas daquela última rodada.

Para preenchimento da coluna "Atributo" a ideia inicial era utilizar, como critério de seleção de atributos, o cálculo, para todos os atributos abordados no segundo questionário, da frequência relativa das opiniões a favor da consideração do atributo na matriz em construção. Seriam, então, selecionados todos aqueles atributos cuja frequência relativa calculada para as respostas da segunda rodada fosse acima de $30 \%$.

No entanto, ao término do processo Delphi, todos os atributos listados tiveram o valor calculado para a frequência relativa das opiniões a favor de sua consideração na matriz acima de 50\%, o que inviabilizou empregar puramente o critério de seleção inicialmente esboçado.

Assim, a coluna "Atributo" da matriz foi preenchida com os atributos, físicos ou relacionados à localização de um edifício de escritórios, que são realmente importantes no sentido de classificar tal produto, seja a repercussão desse atributo direta ou indireta para o usuário

Coincidentemente, todas as afirmações anteriores se repetiram na aplicação do processo nesta pesquisa.

Ainda, segundo explicado por Veronezi, 2004:

A coluna "Fator de importância relativa" foi preenchida com:

[i] - ao lado de cada atributo: peso de cada atributo em relação aos demais atributos do seu grupo / sistema, no sentido de classificar o produto edifício de escritórios (no nosso caso CL) quanto a sua qualidade, sob o ponto de vista de seu usuário; e

[ii] - ao lado de cada grupo / sistema: ajuste do peso de cada grupo / sistema em relação aos demais grupos / sistemas considerados na matriz, no sentido de classificar o produto quanto a sua qualidade, sob o ponto de vista de seu usuário. 
Para preenchimento da coluna "Fator de importância relativa" ao lado de cada atributo, calculou-se, a partir das respostas da segunda rodada do processo Delphi, a moda das opiniões sobre o peso relativo de cada atributo em relação aos demais. $\mathrm{O}$ valor obtido para a moda foi alocado ao lado do respectivo atributo na matriz de atributos.

Neste estudo o preenchimento da coluna "Fator de importância relativa" ao lado de cada grupo / sistema, resultou do tratamento das respostas de uma tabela específica adicionada na segunda rodada do processo Delphi. Ele foi calibrado segundo as respostas obtidas dos especialistas do mercado de CL, focado na função da representatividade desejada (valor arbitrado) para cada grupo.

Diferentemente do Sistema de Certificação da Qualidade de Edifícios de escritórios que contempla duas classificações, Nacional e Regional, o sistema aqui proposto apresenta uma única classificação nacional absoluta.

O valor do fator de importância de cada atributo da matriz deste estudo foi minuciosamente calculado empregando analise estatística das respostas dos especialistas participantes.

Seguindo a base metodológica exposta em Veronezi, 2004, e da mesma forma aqui adotada:

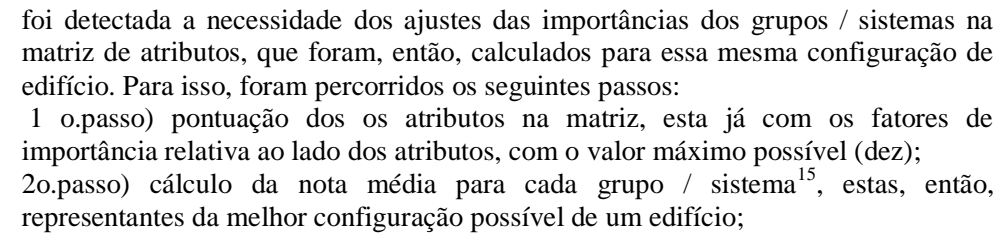

\subsection{Arbitragem das escalas de classificação}

A arbitragem das escalas de classificação foram espelhadas e compradas com o exposto por Veronezi (2004) (Apêndice D) que explica:

Uma escala de classificação, qualquer que seja ela, é caracterizada pelos seguintes aspectos:

[i] - quantidade de categorias que a compõem

[ii] - nome e definição destas categorias;

[iii] - extremos de pontuação de cada categoria.

\footnotetext{
15 Retomando, a nota média para o grupo / sistema resulta da divisão da soma de todos os atributos pontuados e ponderados do grupo / sistema pelo número de atributos que o compõem e que foram pontuados. Esse cálculo é feito pelo algoritmo contemplado na matriz de atributos.
} 
Os procedimentos seguidos para arbitragem das escalas foram os mesmos.

Em linhas gerais, ela foi baseada em pesquisa bibliográfica, entrevistas com PMEBE's e observações no mercado em questão.

Na presente pesquisa foi adotada uma escala de hierarquização baseada em parâmetros a partir da aplicação da Matriz de atributos a diferentes galpões existentes no mercado , dos quais foram extraídos valores intermédios inferiores à nota máxima que pode obter um galpão com uma perfeita adequação em todos seus Atributos avaliados.

Em outras palavras, o galpão avaliado recebe uma pontuação para cada atributo que pode variar da perfeita adequação, quando é atribuída a nota máxima ao atributo, ao não atendimento dos padrões representantes da visão prevalente de mercado, quando é conferida a nota mínima. A soma ponderada do total dos atributos do galpão permite encaixa-o na escala de classificação que gera a opinião sobre categoria / classe dentro do sistema de classificação. A escala de classificação gera uma Certificação da Qualidade Nacional.

Os patamares estabelecidos na escala de classificação têm seus extremos numericamente definidos por quatro (4) categorias identificadas e pontuadas da seguinte forma: AAA (mínimo 630.000 pontos), A (mín. 530.000 pontos), B (mín. 480.000 pontos) e C (mín. 430.000 pontos).

Classe AAA: qualidade mais alta e quase invulnerável.

Classe A: qualidade alta e muito pouco vulnerável

Classe B: qualidade boa e pouco vulnerável.

Classe C: qualidade mínima e muito vulnerável.

\subsection{Validação e calibragem do sistema de classificação}

A matriz de atributos e a escala de classificação arbitradas foram validadas e calibradas através de aplicações deste sistema de classificação a galpões já inseridos nesse segmento do mercado imobiliário brasileiro. Desta maneira, os galpões que receberam avaliação com a Matriz aqui construída, ressaltaram suas similitudes e diferencias, assim por exemplo, prevalecia os pisos com grande resistência, boa localização, alta iluminação, docas cobertas e 
elevadas e esses mesmos galpões se diferenciavam quanto a áreas de apoio, seguridade patrimonial e áreas comuns.

Esta validação e calibragem foram iniciadas com as visitas técnicas a CL previamente selecionados. Estas visitas permitiram o preenchimento, para cada prédio, da coluna "Pontuação para o galpão" da matriz de atributos, cujo algoritmo gerou as pontuações finais para cada galpão, correspondentes a esta primeira rodada de teste do sistema de classificação. Ao término de cada rodada de teste os ajustes necessários eram realizados e o sistema de classificação era novamente testado. Testes e ajustes foram repetidos, utilizando os mesmos edifícios selecionados inicialmente, até que os resultados obtidos foram considerados satisfatórios, conforme explicado a seguir.

Foram selecionados CL bastante distintos entre si para aplicação dos testes com o objetivo de varrer, se não todas, o maior número possível de categorias de classificação. Para selecionálos foi feito um pré-julgamento dos CL segundo parâmetros do NRE/POLI/USP.

Com o fim de garantir que as classes suprema e ínfima das escalas de classificação seriam caracterizadas nessa etapa de validação e calibragem do sistema de classificação, foram abordados nos testes CL que, segundo pré-julgamento do NRE/POLI/USP, no momento em que os testes estavam sendo realizados (segundo semestre de 2015) constituíam exemplares típicos de produtos decadentes e de grande notabilidade.

Da mesma maneira, foram considerados nos testes CL pré-julgados como exemplares de produtos com qualidades intermediárias entre os existentes naquele momento no mercado brasileiro de CL.

A cada rodada de teste, todos esses CL eram envolvidos. Assim, foi possível caracterizar todas as categorias componentes das escalas de classificação, definido-se os extremos de pontuação das mesmas.

A Matriz de atributos final foi aplicada a diferentes galpões como teste do sistema de classificação para, primeiramente, validar e calibrar a matriz de atributos e, seguidamente, obter esses extremos de pontuação e validar e calibrar as escalas de classificação. 
Ao final de cada rodada de teste era verificado o grau de adequação dos resultados às expectativas do NRE/POLI/USP, estas últimas definidas em função da percepção de mercado por essa instituição.

No momento que os testes foram satisfatórios, ficou estabelecido o preenchimento da coluna "Fator de importância relativa" e a matriz de atributos foi considerada validada e calibrada. Consultar Capitulo 7

Segundo Veronezi (2004):

a partir da matriz de atributos validada e calibrada, os extremos de pontuação de cada categoria componente das escalas de classificação foram definidos.

Ao longo dos testes foram considerados, a quantidade de categorias das escalas, bem como seus nomes, adequados. Dessa forma, as escalas de classificação foram consideradas validadas e calibradas, sendo sua configuração final:

i) - quantidade de categorias que as compõem: quatro (4)

ii) - nome destas categorias: AAA, A, B e C, melhor descritas no capítulo 7 deste texto;

iii) - extremos de pontuação de cada categoria: são definidos patamares na escala de classificação, na qual seus extremos estão numericamente definidos para cada categoria: AAA, A, B e C. Cabe ressaltar apenas que foi adotado um valor maior que zero para o piso da ínfima categoria. Tendo sido a matriz de atributos anteriormente validada e calibrada, o processo de validação e calibragem do sistema de classificação foi encerrado. 


\section{SELEÇÃO DA TÉCNICA PARA O DESENVOLVIMENTO DO SISTEMA DE CERTIFICAÇÃO (TÉCNICA DELPHI).}

Existem varias técnicas que podem ser empregadas para comparar características associadas em um determinado produto. Porém, dentro do NRE/POLI/USP existe um sistema de classificação de edifícios de escritório o qual foi desenvolvido empregando a técnica Delphi. Hoje em dia este sistema de classificação de edifícios de escritório é oferecido ao mercado e comporta um diferencial de qualidade devido às metodologias e pesquisas envolvidas na sua criação.

A classificação que objetiva o presente trabalho ficará sob a chancela do NRE/POLI/USP, e, tendo em consideração o bom desempenho da técnica Delphi na classificação de edifícios de escritórios, decidiu-se empregá-la na classificação de CL.

Existe a técnica Delphi tradicional e também há variações, e, segundo Needham; Loë (1990), a técnica tradicional é eficiente quando um estudo envolve vários participantes com o papel de julgar quesitos, produzindo uma opção ou uma série precisa de opções.

Ao se ter participantes anônimos e isolados fisicamente, a técnica Delphi consegue coletar e confrontar sistematicamente as apreciações sobre o tema pesquisado.

A metodologia específica para capturar os dados se desenvolve por meio de questionários sequenciais, onde se coletam as opiniões dos participantes. Estes questionários serão cuidadosamente elaborados e analisados em forma sequencial, intercalados com informações resumidas e retorno das respostas anteriores. Os participantes receberão os questionários individualmente, através de correio ou internet, para posteriormente retorná-los preenchidos ao coordenador da pesquisa. Segundo CHAPMAN (2001), o coordenador da pesquisa processa as informações, as confronta e as sumariza, elaborando os resultados disponibilizando-os aos participantes junto com o questionário da rodada seguinte. A identidade das opiniões será sempre omitida, porém os participantes podem alterar suas respostas anteriores em função do feedback.

O grupo de especialistas que irá participar da pesquisa vai emitir um conjunto de opiniões que devem ser avaliadas e classificadas. Para obter um consenso confiável destas opiniões, será utilizada a técnica Delphi como ferramenta de análise da série de questionários intensos 
entremeados com feedback controlado, pois o principal objetivo da técnica Delphi é "obter o mais confiável consenso de opinião de um grupo de especialistas através de uma série de questionários intensos entremeados com feedback controlado de opiniões" (DALKEY; HELMER, 1963, p.458 apud ROWE; WRIGHT, 1999, p.354), no qual as características essenciais são, i) um processo de investigação onde seja preservado o anonimato dos participantes, ii) um conjunto de questões com sucessivas iterações e com feedback controlado das respostas do grupo, e iii) tratamento estatístico das respostas.

Adotando a metodologia de coletar as respostas à distancia, os participantes ficam no anonimato e "evita a identificação de específica resposta com determinado membro do grupo. Assim, os participantes têm a liberdade de alterar suas opiniões sem precisar admitir publicamente um provável erro" (VERONEZI, 2004). Contudo, o fato das ideias ser originadas por participante renomado, não significa que sejam melhores ou mais importantes na sua essência, (SAITO; SINHA, 1991).

Portanto, "o resultado não é afetado pela dominância de alguns membros do grupo, o que inibiria a criatividade e livre geração de ideias" (VERONEZI, 2004). Assim, o raciocínio é independente e os pontos de vista mais pessoais, de acordo com Gupta; Clarke (1996).

O método Delphi especifica o anonimato, com o objetivo de eliminar possíveis distorções e tendências que se originam na insegurança dos participantes diante da sua concorrência direta, assim como pressões políticas ou medo de rever disposições e participação de indivíduos de personalidade muito forte e impositiva ou de renome, segundo Campana (1988).

A coleta de opiniões, baseada no questionamento à distância do Delphi, tem, ainda, a vantagem de facilitar a obtenção de informação de especialistas geograficamente dispersos (HAMILTON; BRESLAWSKI, 1996).

Segundo Veronezi (2004), “o feedback controlado é a única maneira de os participantes de uma sequência Delphi interagirem. O coordenador ou analista do processo extrai das respostas recebidas as informações relevantes à questão em estudo e apresenta-as aos participantes junto com o questionário da rodada seguinte". Ainda, conforme Veronezi (2004), "cada participante é informado da opinião coletiva do grupo". Isto, conforme Spínola (1997), leva a um aprendizado. As opiniões da maioria e da minoria podem ser conservadas na rodada seguinte. Ligado ao anonimato, o feedback incita os participantes a revisarem suas respostas. 
É importante enfatizar que o feedback evita que o grupo se afaste do objetivo proposto pelo Trabalho. Portanto, a cada feedback a técnica Delphi extrai de maneira conveniente e adequadamente a opinião dos participantes.

Quando se está diante de uma técnica de geração de ideias, os participantes são variados e devem ser selecionados de um grupo de especialistas do campo em questão. Isto é parte do sucesso do Delphi, pois, "a pertinência das opiniões depende da relevância da expertise dos participantes: questões palpáveis são palpáveis somente se relacionadas ao domínio de conhecimento dos específicos especialistas... Delphi foi concebido para uso com especialistas" (ROWE; WRIGHT, 1999, p.368).

É importante que os participantes tomem consciência da relevância da pesquisa, devem estar motivados em participar do processo e entender que a técnica Delphi tem avaliações positivas de desempenho ao se pesquisar geração de ideias de diferentes participantes, neste caso, Participantes do Mercado Brasileiro de Condomínios Logísticos.

Tendo presente que para cada aplicação da técnica Delphi existe certa flexibilidade para adaptar o desenvolvimento do processo, no presente trabalho vai se tomar como guia os questionários e números de rodadas aplicados e modelo de matriz de atributos desenvolvidos na dissertação "Sistema de Certificação da Qualidade de Edifícios de Escritórios no Brasil”, desenvolvida no NRE da Escola Politécnica da USP

No Delphi clássico, a rodada inicial é aberta e desestruturada, assim aos especialistas contam com uma relativa liberdade para identificar os pontos que consideram mais importantes. Rowe; Wright (1999), após analisar os resultados da primeira rodada, os questionários são estruturados e a partir da segunda rodada vai existir uma serie de opiniões que são a base da estrutura das próximas rodadas.

Porem, no presente trabalho vai ser apresentada uma matriz de atributos estruturada, já na primeira rodada. Esta variação do Delphi esta apoiada na metodologia utilizada na dissertação de mestrado: "Sistema de Certificação da Qualidade de Escritórios no Brasil", oferecido pela escola Politécnica da Universidade de São Paulo, no qual, Veronezi (2004), estabelece que "a primeira rodada já é estruturada para simplificar a aplicação para o monitor e para os respondentes. Outro objetivo de empregar a primeira rodada já estruturada é evitar que o resultado desta rodada não atenda o estudo proposto". Esta última afirmação deve-se à 
liberdade de opinião dos participantes (Ferraz, 1993).“Além disso, a própria formulação dos problemas, excessivamente detalhados ou demasiadamente ambíguos, acaba por reduzir a qualidade das informações obtidas dos especialistas" (CAMPANA, 1988).

A metodologia do Delphi marca como variável importante o número de questões a ser empregadas em as rodadas. Assim, quando se tem uma grande quantidade de questões, os riscos que podem surgir são: i) que o especialista não tenha tempo de responder todas as perguntas com o devido cuidado, ou ii) não realiza o total do questionário e decide não devolve-o para o monitor, (Ferraz 1993).

Em quanto à eficiência da técnica Delphi pela variável do número de rodadas, nos estudos empíricos onde foi utilizada, se observa que foram empregadas entre 2 a 7 rodadas. Conforme 27 estudos revisados (Rowe; Wright 1999).

Ainda, mediante estes 27 estudos revisados foram determinados que, a quantidade de especialistas envolvidos varia entre 3 a 98, sendo que no $89 \%$ dos casos se tinha até 25 membros.

Ao se ter um estudo que envolve a geração de ideias, a técnica Delphi pode ser considerada como uma tática para abordar as questões. Mediante esta técnica, é possível atingir a máxima convergência das respostas, para alcançar o objetivo em estudo. 


\section{DESCRIÇÃO GERAL DO SISTEMA DE CERTIFICAÇÃO.}

Tal como foi descrito na introdução, a estrutura deste sistema de certificação de condomínios logísticos no Brasil segue o formato geral e as bases teóricas e científicas do "Sistema de Certificação da Qualidade de Edifícios de escritórios no Brasil”, por este motivo se mantiveram a descrição dos seus principais elementos constituintes, com as devidas adaptações e correções. Assim a estrutura do sistema de certificação da presente pesquisa é:

i) sistema de classificação: os empreendimentos de condomínio logístico são classificados conforme o estado de determinados atributos, tanto dos galpões quanto do conjunto de elementos do condomínio em análise;

ii) emissão de um certificado: o Núcleo de Real Estate da Escola Politécnica da USP, realiza um analise do empreendimento e define a inserção de cada galpão no sistema de classificação segundo certa categoria / classe;

iii) procedimento para verificação da validade deste certificado; $\mathrm{e}$

iv) mecanismos para atualização do sistema de classificação.

Ao se implantar um sistema de certificação deve se ter presente que a qualidade de um empreendimento pode se ver afetada com o tempo (perecibilidade), por este motivo se dispõe dos dois últimos itens como complemento.

O sistema de classificação apresentado como um dos subsistemas do certificado da qualidade esta composto por:

i.1. matriz de atributos; é aplicada aos projetos de CL para analisar sua qualidade e produz uma pontuação para cada galpão avaliado,

i.2. escala de classificação; cada galpão avaliado optem uma pontuação que fica enquadrado em uma escala de classificação hierarquizada e particular; e

i.3. comitê de classificação: ao final da avaliação, emite o parecer sobre a inserção do galpão analisado no sistema de classificação segundo certa categoria. A existência do comité se faz necessária para transmitir credibilidade ao sistema de classificação. Nesse sentido, foi adotado o REGIMENTO PARA AS DECISÕES DO COMITÊ DE CLASSIFICAÇÃO, que foi criado 
para o "Sistema de Certificação da Qualidade de Edifícios de escritórios no Brasil" e esta apresentado no Apêndice E desta dissertação.

Do mesmo modo que no "Sistema de Certificação da Qualidade de Edifícios de escritórios no Brasil", a figura que segue descreve a estrutura do sistema de certificação proposto neste trabalho.

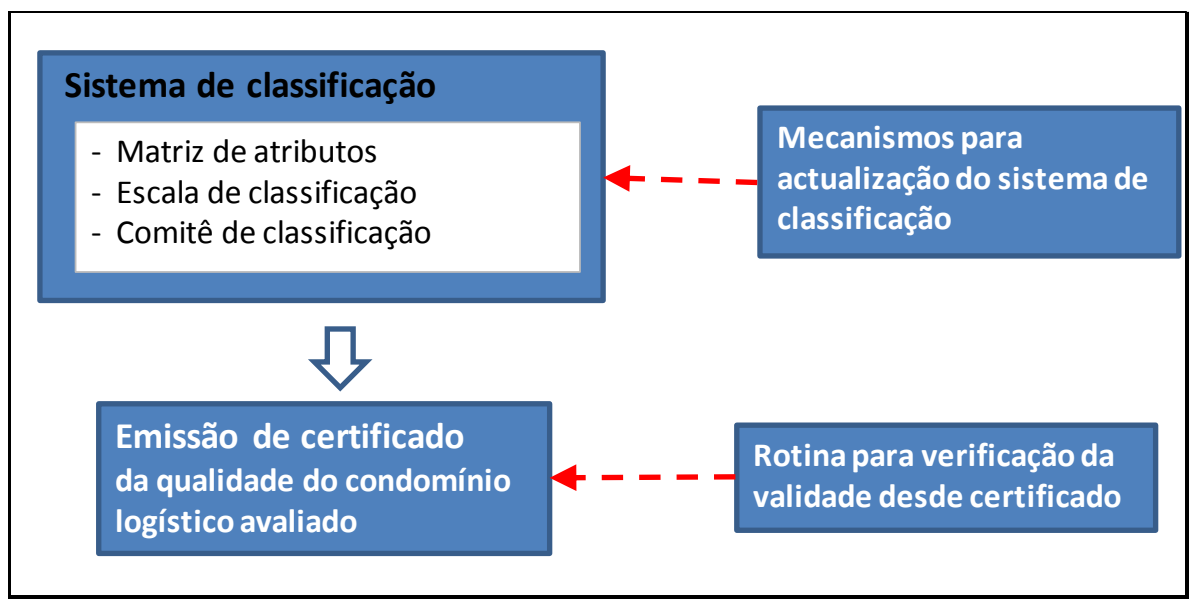

Figura 16 - Sistema de certificação da qualidade de condomínios logísticos no Brasil.

Cada um dos componentes mostrados é igualmente importante para o funcionamento do sistema de certificação de maneira unificada e estão descritos no presente capítulo.

\subsection{Sistema de classificação}

Como apresentado na introdução deste capítulo, este subsistema do sistema de certificação é formado por matriz de atributos, escala de classificação e comitê de classificação, e são detalhados a seguir. Nele se baseia a consolidação da categoria / classe na qual o galpão analisado será inserido, o que representa a qualidade do mesmo, sob o ponto de vista do usuário. Há procedimentos e regras que devem ser seguidos para consolidação da classificação do galpão em análise, o que está descrito no subitem "Processo de classificação". 


\subsubsection{Matriz de atributos.}

A matriz de atributos conduz a análise da qualidade de um galpão que forma parte de um condomínio logístico, segundo o enfoque definido nesta pesquisa. Tão importante quanto a estrutura da matriz de atributos, é a maneira como a mesma deve ser preenchida por ocasião da análise de um galpão. Apesar da estrutura da matriz de atributos ser rígida e já contemplar todos os algoritmos necessários para produzir as pontuações finais dos galpões, seu preenchimento incorreto leva a resultados desvirtuados.

\subsubsection{Estrutura da matriz de atributos.}

Para compreender a estrutura da matriz de atributos serão utilizadas as figuras a seguir. $\mathrm{Na}$ figura 17 se apresenta uma síntese dos subsistemas / grupos que compõem a matriz e da quantidade de atributos que compõem cada um. A seguir, na figura 18, se apresenta um desses grupos com exemplos dos atributos considerados e a forma final da matriz de avaliação. No entanto, os atributos que compõem cada um desses grupos/ sistemas não estão listados pois essa simplificação é suficiente para a compreensão da matriz, O Apêndice B contem a Matriz inicial completa.

Esta pesquisa não busca estabelecer conceitos rígidos para projetos de $\mathrm{CL}$ em desenvolvimento no Brasil, ou seja, determinado projeto não deve ser definido a partir da matriz de atributos. Por isso, esta matriz é sigilosa e não está apresentada em sua íntegra.

MATRIZ DE ATRIBUTOS

\begin{tabular}{|c|c|c|c|}
\hline $\begin{array}{c}\text { CÓDIGO } \\
\text { Do } \\
\text { SUBSIS- } \\
\text { TEMA }\end{array}$ & SUBSISTEMAS & \begin{tabular}{|c|} 
FATOR DE \\
IMPORTÂN- \\
CIA \\
RELATIVA \\
0 A 100 \\
\end{tabular} & \begin{tabular}{|c|}
$\begin{array}{c}\text { Atributos } \\
\text { dos } \\
\text { subsistemas }\end{array}$ \\
172 \\
172
\end{tabular} \\
\hline 100 & 1. Sistema Elétrico do Galpão & & 10 \\
\hline 200 & 2. Eficiência do Projeto & & 40 \\
\hline 300 & 3. Sistema de lluminação & & 10 \\
\hline 400 & 4. Sistema de Hidráulica & & 15 \\
\hline 500 & 5. Sistema de Detecção e Combate a Incêndio interno e externo & & 14 \\
\hline 600 & 6. Sistema de Telecomunicação e Informática & & 9 \\
\hline 700 & 7. Áreas de apoio. & & 21 \\
\hline 800 & 8. Sistema Elétrico do condomínio & & 13 \\
\hline 900 & 9. Circulação, manobras e estacionamento & & 17 \\
\hline 1000 & 10. Segurança Patrimonial & & 13 \\
\hline 1100 & 11. Localização & & 10 \\
\hline
\end{tabular}

Figura 17 - Grupos / Sistemas componentes da matriz de atributos e número de atributos contidos em cada grupo. 


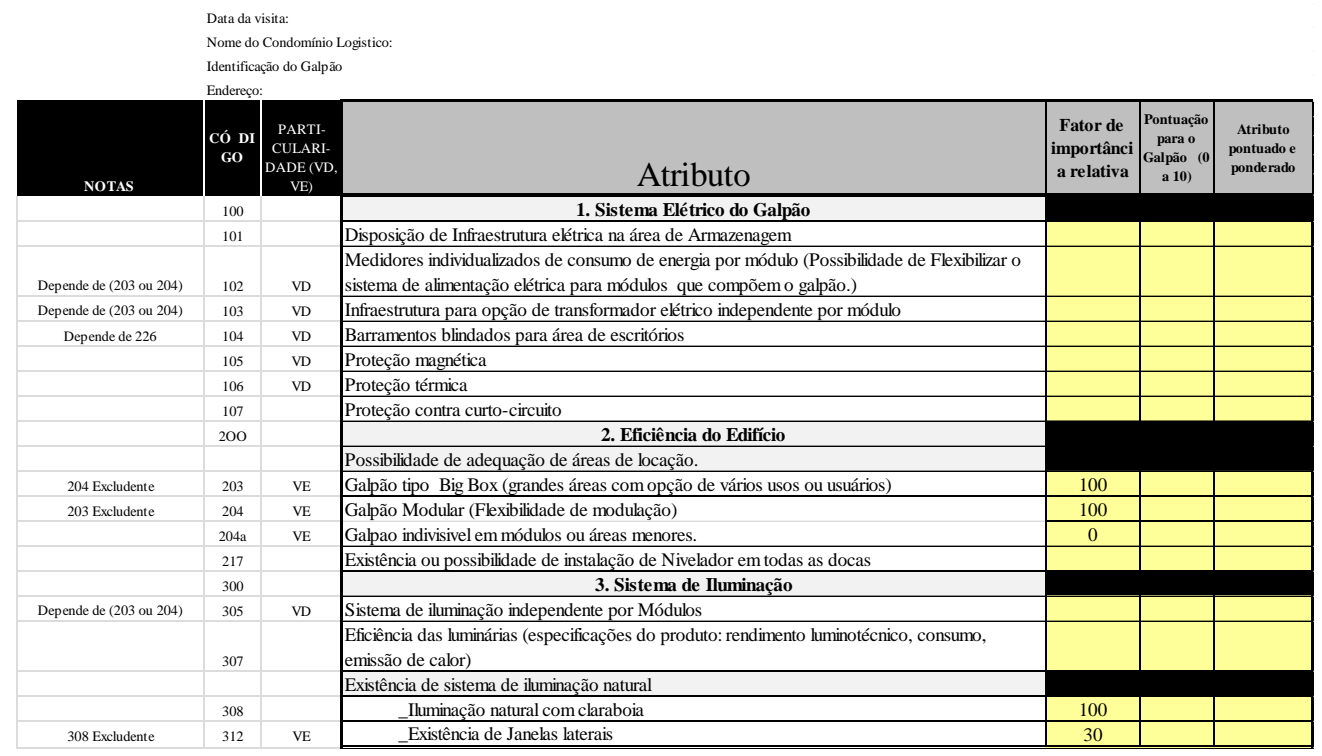

Figura 18 - Formato e componentes da matriz de atributos.

As colunas "Atributo" e "Fator de importância relativa" são fixas, independentemente do galpão em análise. O preenchimento dessas colunas foi feito nesta pesquisa, o que está explicado no capítulo 4.3 “avaliação e calibragem”.

A coluna "Atributo" descreve, em forma de texto, todos os atributos físicos e os relacionados à localização de um condomínio logístico que, sob o enfoque do usuário, devem ser avaliados para sua classificação.

As características envolvidas com a administração predial não são consideradas na matriz aqui apresentada. Portanto, este sistema de classificação não abrange a avaliação da gestão dos CL, por ser uma condição volátil (contratações temporais ou condicionais) e, caso fosse considerado, poderia alterar a classificação do edifício em prazo inferior à validade de seu certificado da qualidade.

Dentro da matriz, esses atributos estão agrupados em subsistemas identificados por um título e um código de grupo, ao topo. A ordem em que os grupos estão listados tem por objetivo conduzir a análise do galpão de forma fluida, não tendo nenhuma relação com o grau de 
importância do grupo / sistema dentro da matriz de atributos. A mesma justificativa é válida para a ordenação dos atributos dentro de cada grupo / sistema.

A coluna identificada como "Fator de importância relativa" é preenchida por números que representam:

i) - ao lado de cada atributo, a importância dele, em relação aos demais atributos considerados no grupo / sistema, no sentido de classificar cada galpão quanto a sua qualidade, sob o ponto de vista do usuário. Para esclarecer este conceito foi extraído da figura 3-3: se, visando classificar um galpão quanto a sua qualidade, o "atributo 102" do grupo "SISTEMA ELETRICO DO GALPÃO"é mais importante que o "atributo 101", então, o "atributo 102" apresenta maior valor para seu fator de importância relativa que 101;

ii) ao lado de cada grupo ou sistema, se tem o valor de ajuste da importância do grupo / sistema em relação aos demais grupos / sistemas considerados na matriz, no sentido de classificar um galpão integrado ao condomínio logístico, quanto a sua qualidade, sob o ponto de vista do usuário. Esse peso atribuído a cada grupo / sistema multiplica a nota média resultante para o grupo / sistema ${ }^{16}$. Dessa forma, a importância de cada grupo / sistema no sentido de classificar cada galpão é corretamente ponderada, independentemente do número de atributos que o compõem e do fator de importância relativa dos mesmos. As definições dos fatores de importância relativa dos grupos / sistemas está devidamente explicada no Capítulo “7.1 Calibragem e Aplicação da Matriz de Atributos".

A coluna "Pontuação para o galpão" é preenchida somente por ocasião de avaliação de determinado galpão. Este preenchimento obedece a critérios que devem ser detalhados, pois são de suma importância dentro do sistema de classificação. Por isso está tratado separadamente no subitem "6 11.1.2 Forma de pontuação do galpão ". Nesse mesmo subitem está explicada a coluna "Particularidade", que, através de siglas, indica restrições ou vínculos para aplicabilidade da avaliação de determinados atributos.

16 Nota média para o grupo / sistema: resulta da divisão da soma de todos os atributos pontuados e ponderados do grupo / sistema, o que está explicado a seguir, pelo número de atributos que o compõem e que foram pontuados. 
A coluna "Atributo pontuado e ponderado", ao lado de cada atributo, é preenchida com o resultado da multiplicação do fator de importância relativa do atributo, que é o mesmo independentemente do galpão, pela pontuação atingida por este atributo no caso específico do galpão em análise, esta última resultante do julgamento do relator do comitê de classificação.

A coluna "Atributo pontuado e ponderado", ao lado de cada grupo / sistema, é preenchida com a nota do grupo / sistema pontuado (através de seus atributos) e ponderado (através de seu fator de importância relativa). Os cálculos de tal nota seguem os seguintes passos:

$1^{\circ}$. passo) cálculo da pontuação do grupo / sistema: soma-se todos os atributos pontuados (régua de graduação) e ponderados (fator de importância relativa) do grupo / sistema;

$2^{\circ}$. passo) cálculo da nota média para o grupo / sistema: divide-se a pontuação do grupo / sistema pelo número de atributos que o compõem e que foram pontuados ${ }^{17}$;

$3^{\circ}$.passo) cálculo da nota do grupo / sistema pontuado e ponderado :multiplica-se a nota média para o grupo / sistema pelo seu fator de importância relativa. A pontuação final do galpão resulta da soma das notas dos grupos / sistemas pontuados e ponderados. O algoritmo desses cálculos já está contemplado na estrutura da matriz de atributos, o que agiliza a produção da pontuação final do galpão e impede erros oriundos de cálculos.

Para cada galpão analisado são obtidas as pontuações finais, representando sua classificação nacional.

\subsubsection{Forma de pontuação do galpão}

Ao analisar um galpão, a única informação a ser preenchida dentro da matriz de atributos é a coluna "Pontuação para o galpão". Todas as outras informações da matriz de atributos são rígidas e pré-estabelecidas, independente do galpão em avaliação.

O relator do comitê de classificação, encarregado da vistoria do galpão, preenche essa coluna com notas, ao lado de cada atributo, em função do estado dos atributos por ele detectado. Este preenchimento, obviamente, não é cartesiano, como todo processo que envolve julgamento,

17 Há alguns atributos da matriz que às vezes não são pontuados. Isto depende das características do edifício em análise, o que está explicado no subitem "3.1.1.2 Forma de pontuação do edifício de galpões”. Os atributos não pontuados são desconsiderados para o cálculo da nota média para o grupo 
pois resulta da opinião do relator. No entanto, há critérios a serem seguidos para tal preenchimento criados para impedir desvios que não sejam decorrentes da subjetividade intrínseca ao processo de certificação.

O galpão em avaliação recebe uma pontuação para cada atributo, atribuída em função do grau de adequação do atributo aos mais altos padrões de construção vigentes, correspondentes à visão prevalente de mercado (necessidades do mercado de logística). A pontuação pode variar da perfeita adequação, quando é atribuída a nota máxima ao atributo, ao não atendimento dos padrões representantes da visão prevalente de mercado, quando é conferida a nota mínima ao atributo. À frente de cada atributo listado na coluna "Atributo" da matriz, há uma breve citação de padrões de construção possíveis de serem detectados durante as análises dos galpões. Essas citações balizam e, dentro do possível, nivelam o julgamento dos relatores.

Uma régua de graduação é empregada para esta pontuação dos atributos. A graduação da régua foi estabelecida como sendo a mesma para todos os atributos. Nos casos em que cabe apenas constatar a presença ou a ausência do atributo para o galpão em análise, são usados somente os dois extremos de pontuação da régua, correspondentes a SIM ou NÃO. Nos demais casos, a graduação da régua varia de forma discreta entre 0 e 10, podendo a pontuação assumir qualquer valor inteiro dentro desse intervalo. Os valores 0 e 10 representam as pontuações mínima e máxima possíveis de se obter, respectivamente, enquanto o valor 5 representa o valor exatamente central da escala. Os galpões, mesmo comparando-se aqueles fazem parte do mesmo condomínio logístico, podem possuir características muito distintas entre si. Assim, seria incorreto afirmar que a matriz de atributos elaborada nesta pesquisa é integral e identicamente aplicável a todos os galpões brasileiros. Nesse sentido, para não ferir nem tampouco realçar injustamente a qualidade do produto em análise, foi criada a coluna "Particularidade" na matriz de atributos. Determinados atributos da matriz têm sua avaliação restrita a certas características da edificação, enquanto outros têm sua análise vinculada a um ou mais atributos contidos ou não na matriz. Nesses casos a coluna "Particularidade" é preenchida com uma ou mais siglas (VE, VD, R), explicadas a seguir, e uma breve apresentação do particular vínculo ou restrição é apresentada ao lado da sigla:

i) - VE (avaliação vinculada excludente): as configurações possíveis para o atributo em análise estão apresentadas na forma de subitens desse atributo, o qual está identificado com uma cor diferente na matriz e não possui CÓDIGO. Assim, ao ser detectada determinada configuração para o atributo, apenas o subitem correspondente a tal configuração é analisado 
e pontuado, e as demais configurações, que não podem ser concomitantes àquela detectada, não são passíveis de avaliação.

Para que as configurações excluídas não interfiram na qualidade do produto em análise, elas não devem ser pontuadas, pois assim elas são desprezadas no cálculo da nota média do grupo / sistema, conforme estabelecido em seu algoritmo de cálculo, já explicado.

As configurações possíveis, na sua maioria, apresentam fatores de importância relativa distintos entre si e há sempre aquela configuração cujo fator de importância relativa é zero. O exemplo do exposto esta na figura 3.3, nos atributos "Possibilidade de adequação de áreas de locação.”, contido no grupo "2. EFICIÊNCIA DO EDIFÍCIO” e "Existência de sistema de iluminação natural”, contido no grupo “3. SISTEMA DE ILUMINAÇÃO”.

Especificamente, no exemplo, "Possibilidade de adequação de áreas de locação.” Ao avaliar um galpão, este pode apresentar características que permitem adequar sua área total segundo as necessidades do usuário, onde o usuário pode ampliar ou diminuir a área de locação, aqui existem fatores de importância relativa para cada caso; ou, ainda, é possível que o galpão não possua esta possibilidade de divisão, o que fica considerado através da análise exclusiva do subitem "Galpão indivisível em módulos ou áreas menores", cujo fator de importância relativa é zero. Assim, apenas para um dos subitens listados é preenchida a coluna "Pontuação para o galpão”, permanecendo vazias as pontuações dos demais subitens.

ii) VD (avaliação vinculada dependente): se o a atributo é particularizado desta forma significa que sua avaliação depende de outro atributo também considerado na matriz, este último considerado como atributo núcleo.

Caso o condomínio logístico ou especificamente o galpão prescindam do atributo núcleo, a avaliação terá influencia negativamente na pontuação final do galpão. Assim, se o atributo núcleo não existir no edifício em análise, os atributos a ele vinculados devem receber nota zero para enfatizar o aspecto negativo da edificação. Quando achado o atributo núcleo na edificação em análise, os atributos a ele vinculados devem ser normalmente pontuados, de acordo com o estado detectado pelo relator para estes últimos.

A figura 3-3 apresenta o atributo "Sistema de iluminação independente por Módulos" particularizado com a sigla VD, cujo vínculo, apresentado ao lado da sigla, orienta que esse atributo depende da "Possibilidade de adequação de áreas de locação" que neste caso 
específico remete aos atributos 203 ou 204, segundo seja o caso. Assim, se o galpão a ser classificado não possui flexibilidade de adequação de áreas, o atributo "Sistema de iluminação independente por Módulos" recebe imediatamente pontuação zero. Caso contrário, este último deve ser pontuado de acordo com seu estado detectado pelo relator. Apêndice F

Um galpão que forma parte de um CL deve ser pontuado com os atributos que conformam sua estrutura particular e adicionalmente é pontuado com os atributos oferecidos pelo condomínio ao qual pertence. A soma destes atributos considerados na matriz, classifica o galpão como um produto, devendo ser avaliados os atributos desse produto que influenciam seu desempenho enquanto ambiente adequado ao desenvolvimento das atividades cabíveis.

Assim, avalia-se: o que há na edificação - ou possui as condições para ter - e qual seu estado detectado em relação aos padrões referenciais. Nesse sentido, não é a relação [locador / locatário] que deve ser analisada e, por isso, a informação sobre qual agente provisiona o atributo não interfere na pontuação. Assim, os seguintes critérios também devem ser seguidos para pontuar o galpão:

i) recebem nota em função de seu grau de adequação aos padrões de construção correspondentes à opinião prevalente de mercado: atributos provisionados ao usuário pelo projeto e atributos não provisionados ao usuário pelo projeto, porém, que tenham padrões da qualidade impostos pelo empreendimento;

ii) recebem nota mínima (zero): atributos não provisionados ao usuário pelo projeto e cujos padrões da qualidade possam ser livremente escolhidos pelo ocupante do espaço, a seu critério. A justificativa é que, neste último caso, não se pode avaliar o desempenho do produto galpão de CL em função de particulares posturas de ocupantes ou de possibilidades livres de execução (caso de espaços desocupados).

Assim por exemplo existem galpões que possuem aberturas laterais adicionais para ventilação dos mezaninos, mas essa condição é específica para empresas que precisam dividir o mezanino em vários patamares, essa condição é muito especifica e não se pode julgar como desempenho da edificação em função de posturas particulares assumidas pelos seus ocupantes.

O preenchimento da coluna "Pontuação para o galpão" da matriz de atributos pelo relator do comitê de classificação, segundo todos critérios aqui apresentados e em função de seu julgamento sobre o estado dos atributos do CL em análise, resulta na opinião do relator para 
as pontuações finais do produto em análise. Os demais membros do comitê de classificação fazem uma análise crítica das pontuações conferidas aos atributos pelo relator, podendo alterá- las. Isto está detalhado no subitem "6.1.4 Processo de classificação”. Assim, como o comitê de classificação é constituído por 5 (cinco) membros, incluindo o relator, para cada galpão analisado podem ser geradas até 5 (cinco) pontuações finais diferentes a classificação.

Em suma, ao ser analisado um determinado galpão, as informações geradas pelo preenchimento da pontuação dos atributos na matriz são as finais para ele, referente à classificação nacional assignada. Para cada galpão analisado podem ser geradas até 5 (cinco) pontuações finais para a classificação, em função do grau de discordância dos outros quatro membros do comitê de classificação, que não o relator, com o relatório deste último. $\mathrm{O}$ caminho percorrido dentro do sistema de classificação entre esse ponto, onde pode haver até 5 (cinco) pontuações finais para a classificação do galpão, até a consolidação das classificação nacional do mesmo está explicado nos próximos subitens que descrevem o restante do sistema de classificação.

\subsubsection{Escala de classificação}

O valor da pontuação final do galpão é comparado e encaixado na escala de classificação que gera a opinião sobre categoria / classe segundo que deve ser adjudicado ao galpão no sistema de classificação. A escala de classificação gera uma certificação nacional que encaixa a edificação em certa categoria. Isto está detalhado a seguir.

Os patamares contidos na escala de classificação têm seus extremos numericamente definidos. Estes extremos, analogamente à matriz de atributos, são sigilosos e, por isso, não estão apresentados neste texto, uma vez que não é o objetivo desta pesquisa estabelecer cartilha para projetos de condomínios logísticos no Brasil.

A escala de classificação é constituída por 4 (QUATRO) categorias, identificadas por: AAA, A, B e C.

Se a pontuação final do galpão for menor que o extremo inferior da classe $\mathrm{C}$, significa que a edificação não se enquadra na escala de classificação e, então, o Núcleo de Real Estate da Escola Politécnica da USP (NRE/POLI/USP) não emitirá certificado da qualidade para tal edifício. 
Este patamar limite para a ínfima classe da escala de classificação foi criado considerando que não seria lógico classificar uma mesma categoria galpões que, apesar de apresentarem qualidade inadequada, são passíveis de classificação, ainda que a pior existente, e galpões que, por sua qualidade desprezível, não são passíveis de classificação.

As classes estimadas para este estudo estão aqui definidas e são decorrentes da maior ou menor aderência de medidas realizadas em determinado galpão de um condomínio logístico ao estado desejável destas medidas, definido como referencial. Este referencial abrange um conjunto de atributos do galpão e o estado desejável deste conjunto de atributos, segundo o que se identifica como a opinião prevalente de mercado a respeito das necessidades e anseios do usuário.

Igualmente à pontuação final da edificação, a sugestão da categoria na qual inserir o galpão é particular a cada membro do comitê de classificação. Isso porque, apesar da escala de classificação ser única, as pontuações finais para o galpão podem variar entre os membros desse comitê. Assim, a inserção das pontuações finais para o galpão em análise na escala de classificação pode gerar até 5 (cinco) opiniões diferentes para o galpão.

A consolidação da classificação nacional do galpão segundo sua qualidade se dá em reunião do comitê de classificação. Para tomar essa decisão, este comitê segue rigorosamente regras pré-estabelecidas.

\subsubsection{Comitê de classificação}

Assim com no certificado de classificação utilizado como guia deste estudo e atualmente oferecido pelo Núcleo de Real Estate da escola Politécnica da USP, o comitê de classificação é estruturado segundo Apêndice E.

\subsubsection{Processo de classificação}

Ainda baseado no sistema de certificação guia, a rotina de aplicação deste sistema de certificação inclui etapas públicas e outras sigilosas. Por tanto o este processo de classificação em si é sigiloso. Ele gera o certificado da qualidade do galpão avaliado, pertencente a determinado condomínio logístico, que é público e contém as sínteses do processo de certificação e da classificação obtida para o galpão.

O processo de classificação, que é sigiloso, inclui: 
i. análise do galpão por um relator pertencente ao comitê de classificação: o relator obrigatoriamente visita pessoalmente o edifício;

ii. relatório interno (divulgação restrita ao comitê de classificação) com as constatações do relator a respeito do galpão do condomínio logístico visitado: o relator pontua os atributos do do galpão e do CL visitado em função da condição detectada para os mesmos, seguindo os critérios estabelecidos para preenchimento da matriz de atributos; o relator destaca os principais fatores positivos e negativos do empreendimento em análise;

iii. opinião do relator para a classificação do galpão do CL especificado: considerando a pontuação conferida pelo relator aos atributos do edifício, o algoritmo contemplado na estrutura da matriz de atributos produz a pontuação final para o produto em análise que, ao ser enquadrada na escala de classificação, gera a categoria sugerida pelo relator para inserção do galpão no sistema de classificação nacional;

iv. reunião do comitê de classificação para emissão dos pareceres finais a respeito da categoria nacional na qual inserir o galpão do CL especificado ou para solicitação de nova análise deste galpão por um outro relator.

Há regras que conduzem a tomada de decisão por esse comitê, as quais estão detalhadas no REGIMENTO PARA AS DECISÕES DO COMITÊ DE CLASSIFICAÇÃO, apresentado a seguir através de seus artigos, baseados nos artigos descritos por VERONEZI, 2004: Apêndice F.

\subsection{Certificado da qualidade do galpão avaliado.}

O certificado da qualidade do galpão, do CL especificado, emitido pelo Núcleo de Real Estate da Escola Politécnica da USP define a inserção de dito galpão avaliado no sistema de classificação segundo una categoria nacional, oriunda da aplicação do processo de classificação.

A estrutura do certificado, que é publico, inclui:

i) - síntese do processo de certificação, onde se descreve de maneira concisa, os fundamentos do sistema de certificação, o processo de classificação e cada categoria contemplada pelo sistema de classificação. Apresentados para esclarecer aspectos como a 
imparcialidade da instituição certificadora e a abrangência da análise, realçando que a gestão do condomínio logístico não é avaliada e que são utilizados referenciais nacionais para analisar o desempenho do galpão que conforma o condomínio logístico sob o ponto de vista do usuário. Destaca-se também que as classificações certificadas resultam de julgamento do Núcleo de Real Estate da Escola Politécnica da USP acerca do produto. Estas informações são padronizadas e independem do galpão em análise; e

ii) - síntese da classificação obtida, que é o resumo do estado detectado para o conjunto de atributos, o que justifica a inserção do galpão numa determinada categoria. Aqui são destacados os principais fatores positivos e negativos do produto avaliado, bem como a validade do certificado. Estas informações são particulares a cada galpão analisado, a pesar de existir a particularidade de formar parte de um CL.

O prazo de validade do certificado fica sujeito a ciclos de entrega e implantação de novos projetos de similar categoria, segundo Veronezzi, 2004, fustifica que seja de 3 (três) anos.

\subsection{Rotina para verificação da validade do certificado emitido.}

Tal como apresentado no capítulo "1 INTRODUÇÃO”, os CL formam parte do leque de investimento do mercado imobiliário atual e são conceituados como sendo um ambiente seguro, eficiente e de localização estratégica para as empresas gestoras de logística, o que exige que esses empreendimentos acompanhem as evoluções tecnológicas, de materiais construtivos e de flexibilidade de usuários, bem como a identificação de localizações estratégicas de escoamento. Isso evidencia a perecibilidade da qualidade dos galpões e dos mesmos CL. Por este motivo resulta indispensável estabelecer prazo de validade para o certificado que exprime a qualidade perecível do galpão. O prazo de validade foi estabelecido como sendo de 3 (três) anos a partir da data da certificação. As justificativas para definição deste prazo coincidem com aquelas apresentadas por Veronezi (2004

Em termos gerais, este prazo é função do tempo necessário para reconhecimento de novos padrões (tecnológicos, construtivos, arquitetônicos, organizacionais) pelo mercado somado ao tempo médio necessário para idealização, concepção e implantação de um novo projeto semelhante segundo mostra Veronezzi, 2004. 
Expirado o prazo de validade, o galpão especificado do condomínio logístico definido deve ser novamente submetido ao sistema de certificação para reavaliar sua inserção no sistema de classificação. A rotina de análise é a mesma percorrida para obtenção do primeiro certificado, ou seja:

i. análise do galpão e do respectivo CL por um relator pertencente ao comitê de classificação;

ii. relatório interno com as constatações do relator a respeito do galpão e respectivo CL visitado;

iii. opinião do relator respeito a classificação nacional do galpão; e

iv. reunião do comitê de classificação para emissão dos pareceres finais a respeito da categoria na qual inserir o galpão avaliado, levando em consideração o REGIMENTO PARA AS DECISÕES DO COMITÊ DE CLASSIFICAÇÃO, Apêndice F.

\subsection{Mecanismos para atualização do sistema de classificação}

Como já foi estabelecido, este capitulo foi desenvolvido se adotando e adaptando o capítulo 3 “DESCRIÇÃO GERAL DO SISTEMA DE CERTIFICAÇÃO” da dissertação modelo da presente e ao longo de capítulo se explica que o sistema de classificação, subsistema do sistema de certificação, analogamente ao certificado emitido para determinado galpão de CL, também é perecível. E de igual maneira, os procedimentos para sua atualização não são tão simples quanto aqueles descritos para verificação da validade da certificação, que nada mais é que a reaplicação do processo de classificação ao prédio analisado. Dada a complexidade envolvida para atualização do sistema de classificação, ela é subdividida em duas etapas: Apêndice 


\section{RESULTADO: ENTREGA DO MODELO DE CERTIFICAÇÃO DA QUALIDADE.}

Ao obter a aprovação da dissertação de mestrado, terão sido analisados os processos e devidamente estruturada a certificação de qualidade de CL, para ser oferecida ao mercado.

Além das informações adquiridas via pesquisa bibliográfica, foram feitas entrevistas com professionais consolidados no mercado alvo e foram visitados alguns prédios desse segmento imobiliário.

Tanto o objetivo do estudo, como processo Delphi e o papel dos participantes foram devidamente explicados aos envolvidos nessa fase.

As entrevistas contribuíram na obtenção de atributos para a elaboração do primeiro questionário, mas ficaram muito além da estrutura para a elaboração de uma primeira listagem abrangente.

Desta forma, para elaboração do primeiro questionário recorreu-se também a pesquisa bibliográfica e observação dos projetos visitados. Apêndice B.

\subsection{Calibragem e Aplicação da Matriz de Atributos}

Tal como foi descrito na introdução deste texto, o Sistema de Certificação da Qualidade de Condomínios Logísticos no Brasil esta estruturado a partir de um Sistema de Classificação composto por:

i.1. matriz de atributos;

i.2. escala de classificação; e

i.3. comitê de classificação.

A matriz de atributos avalia cada galpão conforme o estado dos seus atributos, esta matriz foi estruturada conforme a analise das respostas dos PMCLBs Foram recebidos 30 questionários, analisou-se item por item e se calculou a dispersão das respostas em relação à moda e foram encaminhadas para a segunda rodada as respostas sem convergência. Após analise da segunda rodada foi estruturada a Matriz definitiva de atributos, onde cada item definido seu Fator de 
Importância, sua particularidade e as notas a considerar na avaliação, como exemplifica a figura a seguir:

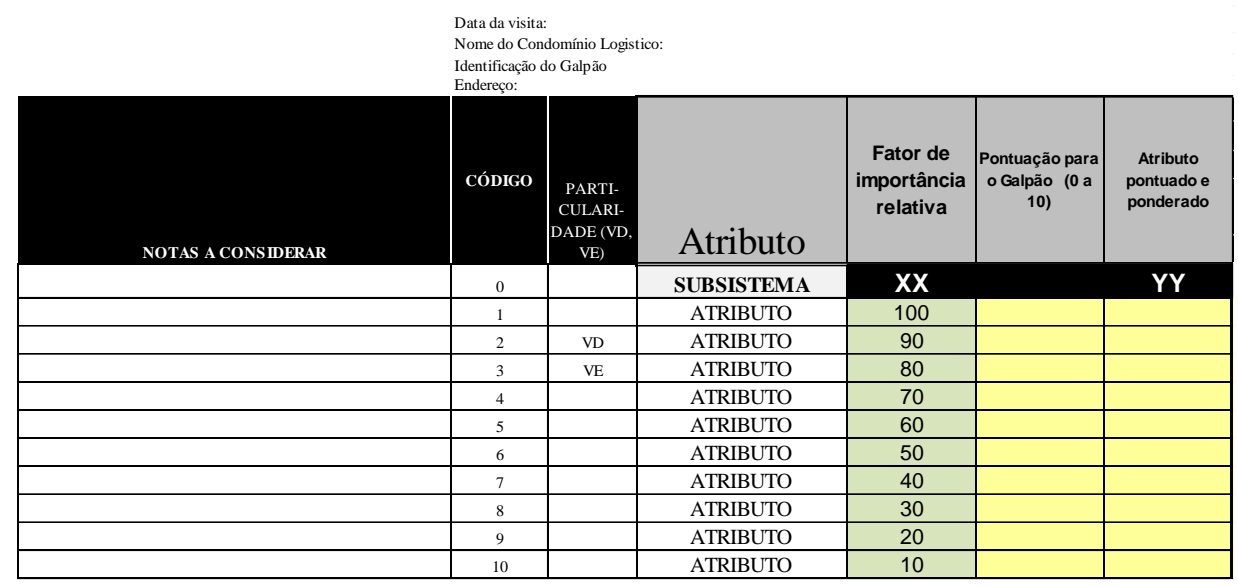

Figura 19 - Estrutura de Matriz Definitiva

No total, a matriz de avaliação possui onze (11) subsistemas, cada um deles tem seu próprio fator de importância (obtido na segunda rodada de questionários) e para conseguir calibrar esta matriz foi necessário aplica-la em galpões de CL consolidados no mercado.

Para conseguir estabelecer a escala de numérica que determina cada categoria na qual encaixa cada galpão avaliado foi necessário aplicar a matriz em CL com caraterísticas diferentes entre si, para logo fazer a comparação da pontuação total adquirida por cada um deles.

Estas pontuações obtidas formaram uma escala e por médio de uma analogia trazida direto da escala do sistema de certificação de Veronezi (2004), empregado como modelo, as categorias estão definidas a seguir e o detalhamento da definição se encontra no Apêndice D.

Classe AAA: qualidade mais alta e quase invulnerável.

Classe A: qualidade alta e muito pouco vulnerável

Classe BBB: qualidade boa e pouco vulnerável.

Classe B: qualidade mínima e muito vulnerável.

> Classe C: qualidade inadequada e altamente vulnerável. 
Assim por exemplo o CL CXX obteve no total 665.564 pontos (para o galpão G1), os quais equivalem aproximadamente a um 75\% do valor máximo que pode ser obtido por um galpão, esta nota encaixa na pontuação que deve ser obtida para classificar como galpão Classe AAA, Figura 20.

Por outra parte o CL PXX obteve no total 467.631 pontos (para o galpão GN), os quais equivalem aproximadamente a um $52 \%$ do valor máximo que pode ser obtido por um galpão, esta nota encaixa na pontuação que deve ser obtida para classificar como galpão Classe C.

\begin{tabular}{|c|c|c|c|c|}
\hline $\begin{array}{c}\text { CóDIGO } \\
\text { Do } \\
\text { SUBSIS. }\end{array}$ & SUBSISTEMAS & \begin{tabular}{|c|} 
FATOR DE \\
IMPORTÂN-CIA \\
RELATIVA
\end{tabular} & $\begin{array}{l}\text { Atributos dos } \\
\text { subsistemas }\end{array}$ & $\begin{array}{c}\text { TOTAL } \\
\text { PONTOS }\end{array}$ \\
\hline & & OA 100 & 169 & 665.564 \\
\hline 100 & 1. Sistema Elétrico do Galpão & & 10 & 57.050 \\
\hline 200 & 2. Eficiência do Projeto & & 39 & 79.744 \\
\hline 300 & 3. Sistema de lluminação & & 8 & 55.125 \\
\hline 400 & 4. Sistema de Hidráulica & & 15 & 40.400 \\
\hline 500 & 5. Sistema de Detecção e Combate a Incêndio interno e externo & & 13 & 84.615 \\
\hline 600 & 6. Sistema de Telecomunicacão e Informática & & 8 & 0 \\
\hline 700 & 7. Áreas de apoio. & & 22 & 55.545 \\
\hline 800 & 8. Sistema Elétrico do condomínio & & 13 & 72.692 \\
\hline 900 & 9. Circulação, manobras e estacionamento & & 18 & 68.000 \\
\hline 1000 & 10. Segurança Patrimonial & & 13 & 87.692 \\
\hline 1100 & 11. Localização & & 10 & 64.700 \\
\hline
\end{tabular}

Data da visita

Nome do Condomínio Logistico: CXX

Identificaçã̃o do Galpão

Endereço: Rod Anhanguera, SP

Figura 20 - Exemplo 1 de aplicação da Matriz Definitiva

O Fator de Importância Relativa (FIR) é um valor fixo para cada atributo e para cada grupo, porém são consideradas informações sigilosas e por este motivo não aparecem especificados nas figuras anteriores. Este FIR tem valores específicos (números enterros $0<\mathrm{FIR} \leq \mathbf{1 0 0}$ ).

A nota obtida pelo galpão coloca-lo na escala de classificação que encaixa numa certa categoria, porem esta Categoria só pode ser consolidada após a avalição do comité de classificação. 


\section{MATRIZ DE ATRIBUTOS}

\begin{tabular}{|c|c|c|c|c|}
\hline \multirow{2}{*}{$\begin{array}{c}\text { CÓDIGO } \\
\text { Do } \\
\text { SUBSIS- } \\
\text { TEMA } \\
\end{array}$} & \multirow[t]{2}{*}{ SUBSISTEMAS } & $\begin{array}{c}\text { FATOR DE } \\
\text { IMPORTÂN-CIA } \\
\text { RELATIVA }\end{array}$ & $\begin{array}{c}\text { Atributos dos } \\
\text { subsistemas }\end{array}$ & \begin{tabular}{|c|} 
TOTAL \\
PONTOS
\end{tabular} \\
\hline & & OA 100 & 164 & 467.631 \\
\hline 100 & 1. Sistema Elétrico do Galpão & & 10 & 50.050 \\
\hline 200 & 2. Eficiência do Projeto & & 39 & 52.821 \\
\hline 300 & 3. Sistema de lluminação & & 7 & 25.000 \\
\hline 400 & 4. Sistema de Hidráulica & & 12 & 23.500 \\
\hline 500 & 5. Sistema de Detecção e Combate a Incêndio interno e externo & & 13 & 69.231 \\
\hline 600 & 6. Sistema de Telecomunicação e Informática & & 8 & 0 \\
\hline 700 & 7. Áreas de apoio. & & 22 & 19.205 \\
\hline 800 & 8. Sistema Elétrico do condomínio & & 13 & 72.692 \\
\hline 900 & 9. Circulação, manobras e estacionamento & & 18 & 29.250 \\
\hline 1000 & 10. Segurança Patrimonial & & 12 & 39.583 \\
\hline 1100 & 11. Localização & & 10 & 86.300 \\
\hline
\end{tabular}

Data da visita:

Nome do Condomínio Logistico: PXX

Identificaçăo do Galpâa

Enderę̧o: ABC, SP

Figura 21 - Exemplo 2 de aplicação da Matriz Definitiva 


\section{REFERÊNCIAS BIBLIOGRÁFICAS}

ATTEBERRY, W; RUTHERFORD,R. Industrial Real Estate Prices and Market Efficiency. Journal of Real Estate Research, Vol. 8, 3, pp. 377-385.

BOUDOUIN, D. Logística-Território-Desenvolvimento: O caso europeu. I Seminário Internacional: Logística, Transportes e Desenvolvimento. Ceará: UFC/CT/DET, 1996, p.105.

BUILDINGS INDUSTRIAL. Ano 1, Ed 1, 2 semestre 2012. Disponível em: <http://www.buildings.com.br>. Acesso em:01 ago. 2014.

BUILDINGS INDUSTRIAL. Ano 7, Ed 26, 3 trimestre 2014, pag14. Disponível em: < http://www.revistabuildings.com.br/revista_buildings/ed26/>. Acesso em:01 nov. 2014.

BUILDINGS INDUSTRIAL. Ano 8, Ed 29, 2 trimestre 2015, pag 28, Panorama do setor de galpões logísticos. Disponível em: 〈http://www.buildings.com.br〉. Acesso em:01 ago. 2015.

Business Park and Development Handbook, second edition

CARDONA, L; SOTO, D; RIVERA, L; MARTÍNEZ, H. Detailed design of fishbone warehouse layouts with vertical travel. International Journal of Production Economics, December. 2013.

CEZAR, G. Açoes diferentes para avançar: Empresas procuram oferecer mais serviços integrados para garantir oas clientes qualidade e redução de custos na entrega de produtos. Revista VALOR SETORIAL, Brasil, março, 2014.

CHAPMAN, R. J. The controlling influences on effective risk identification and assessment for construction design management. International Journal of Project Management, v.19, n.3, p.147-160, April 2001. Disponível em: 〈http://www.probe.br>. Acesso em: 20 oct. 2014.

COLLIERS INTERNATIONAL. Brasil Market Report Industrial: relatório de pesquisa. São Paulo: Collers, 2010a. 6p.

COLLIERS INTERNATIONAL. Brasil - São Paulo - Research \& Forecast Report. São Paulo: Collers, 2010b. 4p 
COLLIERS INTERNATIONAL. Brasil Market Report Industrial: relatório de pesquisa. São Paulo, Segundo trimestre, 2014.

COLLIERS INTERNATIONAL. Brasil Market Report Industrial: relatório de pesquisa. São Paulo, Terceiro trimestre, 2014.

CROSBY, N. The basis of valuations for secured commercial property lending in the UK. Journal of European Real Estate Research, v. 4, n. 3, p.226, 2011.

DALMAU. R; ROBUSTÉ,F, 2002. Um nuevo concepto de plataforma logística urbana. $V$ Congresso de Ingeniería Del Transportes. Santander - Espanha. CIT

D'Andrea, Raffaello. Guest Editorial: A Revolution in the Warehouse: A Retrospective on Kiva Systems and the Grand Challenges Ahead. IEEE Transactions on Automation Science and Engineering, v. 9, n. 4, p. 638, oct. 2012.

DIAS, A. Entenda o que são os Condomínios Logísticos. Santos-SP Disponível em: http://www.adrianodiasadvocacia.adv.br/files/ENTENDA_O_QUE_S_O_OS_CONDOM_NI OS_LOG_STICOS.pdf Acesso em nov de 2014.

DINIS, H.; RIGHI, R. Projeto arquitetônico e urbanismo dos condominios industriais e Logisticos em São Paulo... Cadernos de Pós-Graduação em Arquitetura e Urbanismo. Universidade Presbiteriana Mackenzie; São Paulo; Disponivel em http://editorarevistas.mackenzie.br/index.php/cpgau/article/viewFile/Dinis.2013.1/4471 Acess o em 17 de jan de 2015 .

DUBKE, FERREIRA E PIZZOLATO, Plataformas Logísticas: características e tendências para o Brasil, XXIV Encontro Nac. de Eng. de Produção - Florianópolis, SC, Brasil, 2004.

ETCHEVERRY, C. Panorama do mercado de galpões para logística. In:Seminário Centros De Distribuição E Condominios Logisticos/Industriais, 1, 2011, São Paulo. Apresentações.... São Paulo: Iman, 2011.

FERRAZ, R. M. O. L. Ligação aérea Rio - São Paulo: análise da demanda pelo método Delphi. 1993. 199p+apêndices. Dissertação (Mestrado) - Escola Politécnica, Universidade de São Paulo. São Paulo, 1993. 
GUPTA, U. G.; CLARKE, R. E. Theory and applications of the Delphi technique: a bibliography (1975-1994). Technological Forecasting and Social Change, New York, v.53, n.2, p.185-211, October 1996. Disponível em: http://www.probe.br>. Acesso em: 28 jan. 2002.

HAMMOND, J. S.; KEENEY, R. L.; RAIFFA, H. Decisões inteligentes. Rio de Janeiro: Campus, 2004.

INSTITUTO DE LOGÍSTICA E SUPPLY CHAIN - ILOS. Terceirização Logística no Brasil. Rio de Janeiro, 2009

INSTITUTO DE LOGÍSTICA E SUPPLY CHAIN (ILOS, 2012) Análise Dos Condomínios Logísticos No Brasil http://www.ilos.com.br/web/analise-dos-condominios-logisticos-nobrasil/?print=pdf Acesso em: 08 maio. 2015.

INSTITUTO DE LOGÍSTICA E SUPPLY CHAIN - ILOS. Condomínios logísticos no Brasil: a visão dos operadores logísticos. Rio de Janeiro, 2013.

INSTITUTO DE LOGÍSTICA E SUPPLY CHAIN (ILOS, 2016) O Fenômeno Dos Condomínios Logísticos http://www.ilos.com.br/web/tag/condominios-logisticos/ . Acesso em: 11 jun. 2016.

IVISTA ESTRATÉGIA IMOBILIÁRIA. Publicação eletrônica disponível em: <www.ivista.com.br.>. Acesso em: 04 jun. 2016.

JAKUBICEK, P ; WOUDSMA, C. Proximity, land, labor and planning? Logistics industry perspectives on facility location. Transportation Letters, v. 3, n. 3, p.162, 2011.

Kimimoto, C; Relva, L; Junior, E. Dondominios Logísticos: Estudo de Caso Bauru Business Park. 2014.

LIMA JUNIOR, J. R. Boletim técnico da escola politécnica da USP, BT/PCC/144, qualidade de empreendimento na construção civil- inovação e competitividade. São Paulo 1995.

LIMA JUNIOR, J. R. Boletim técnico da escola politécnica da USP, BT/PCC/153,Princípios para análise de qualidade de empreendimentos: o caso dos empreendimentos de base imobiliária. São Paulo: Escola Politécnica, pag10. Universidade de São Paulo, 1995. 
ROCHA LIMA Jr., João da, Eliane Monetti, and Claudio Tavares de Alencar. 2010. Real Estate Fundamentos Para Análise de Investimentos. 1a edição. Elsevier.

KIMIMOTO, C.F.; RELVA,L.C.; . JUNIOR, E.R. Condominios Logisticos: Estudo de caso Bauru Business Park. Fatec, Lins-São Paulo. Disponivel em http://www.baurubusinesspark.com.br/site/wp-content/uploads/2014/12/ArtigoCondom\%C3\%ADnios-Log\%C3\%ADsticos-Estudo-de-caso-Bauru-Business-Park.pdf. Acesso em Nov de 2014.

MACHADAO, T.F. Condomínios modulares para fins logísticos na RMSP: Metodologia de avaliação. Dissertação de mestrado. Instituto de pesquisas tecnológicas do estado de São Paulo, 2013.

MICHAELIS -on-line. Dicionário de Português Online. Disponível em <http://michaelis.uol.com.br/>. Acesso em: 3 de fev. 2015.

NEEDHAM, R. D; LOË, R. C. de. The policy Delphi: purpose, structure andapplication. The Canadian Geographer, v.34, n.2, p.133-142, 1990.

OLIVEIRA, S. G. Condomínios logísticos industriais, do projeto a operação. In: Seminário Centros De Distribuição E Condomínios Logísticos/Industriais, 2011, São Paulo. Apresentações.... São Paulo: Iman, 2011. http://www.almi.com.br/condominios-de-galpoeslogisticos-mercados-e-perspectivas

PASSONI, F.; MONETTI, E. O mercado industrial de condomínios de galpões modulares para locação na região metropolitana de São Paulo: histórico da implantação e o desempenho de mercado atual. In: SEMINÁRIO INTERNACIONAL DA LARES, São Paulo, 2006.

Poletto, P; A Qualidade Da Oferta Do Novo Estoque De Condomínios Logísticos Com Foco Na Demanda E No Cenário Econômico Atual. Coluna do NRE-POLI na Revista Construção e Mercado, Julho, 2011.

RABIANSKI, J. S. ; Seagraves, P. A. Demand for warehouse and distribution center space. Real Estate Issues, v. 36, n. 1, p.24, 2011. 
ROWE, G.; WRIGHT, G. The Delphi technique as a forecasting tool: issues and analysis. International Journal of Forecasting, v.15, n.4, p.353-375, October 1999. Disponível em: <http://www.elsevier.com/locate/ijforecast>. Acesso em: 17 oct.2014.

SAITO,M.; SINHA, K. C. Delphi study on bridge condition rating and effects of improvements. Journal of Transportation Engineering, v.117, n.3, p.320-334, may/jun. 1991.

SONNEMAN, D. Challenges In Appreising "Simple"Warehouse Properties. Appraisal Journal, v. 69, n. 2, p. 174, abr. 2001.

SHU, J., TEO, C.-P., \& SHEN, Z.-J. M. Stochastic transportation-inventory network design problem. Operations Research, v. 53, n. 1, p. 48, 2005.

SHU, J. An efficient greedy heuristic for warehouse-retailer network design optimization. Transportation Science, 44(2), 183-192. v. 44, n. 2, p.183, 2010.

SPÍNOLA, A. W. de P. Técnica prospectiva Delphi: abordagem teórico prática. São Paulo: SM Gráfica e Editora Ltda, 1997. 30p.

TACHIBANA L, H. Gerenciamento de riscos de desenvolvimento em empreendimentos industriais/logísticos: o caso de um condomínio logístico em Ribeirão Preto - São Paulo, 2013. 103 p.

TELECOTRANS. (1999) Plataformas logisticas y centros de transporte de mercancias em Espana. Uma visión de la situación actual y propuesta de intervencion. Um resumen de conclusiones de três estúdios para el ministério. Disponível em: <www.telecotrans.es> Capturado em 02/08/2013.

TWIST, D. The impact of radio frequency identification on supply chain facilities. Journal of Facilities Management, v. 3, n. 3, p.226, 2005.

VENANZI, D. Os ganhos das novas configurações da indústria automobilística: condomínio industrial e consórcio modular. Guia de logística. Disponível em:<http://www.guialog.com.br/ARTIGO339.htm>. Acesso em: Jan . 2014. 
VERONEZI, A. Sistema de Certificação da Qualidade de Edifícios de Escritórios no Brasil. Dissertação de mestrado, escola Politécnica, universidade de São Paulo, 2004.

VIANA , F. Condomínios Logísticos No Complexo Industrial E Portuário De Suape-Pe Informe Técnico do ETENE, dezembro, 2013.

http://www.tecnologistica.com.br/destaque/revista-tecnologistica-trazedicao-especial-de-condominios-logisticos/principais players condomínios logísticos Brasil Ed 203. 
APÊNDICE A -APLICAÇÃO DA TÉCNICA DELPHI, VERONEZI (2004). 


\subsubsection{Aplicação da técnica Delphi}

O objetivo dessa fase foi detectar as opiniões prevalentes sobre quais atributos dos edificios brasileiros de escritórios deveriam compor a matriz de atributos e qual a importância de cada atributo componente em relação aos demais.

A aplicação da técnica Delphi com a sequêencia de duas rodadas de questionários enviados aos PMEBE's conduziu a esse objetivo. A estrutura da metodologia Delphi particular a este estudo está explicada no capítulo "5 MÉTODO UTILIZADO PARA ARBITRAGEM INICIAL DA MATRIZ DE ATRIBUTOS".

A quantidade de PMEBE's envolvidos ao longo da aplicação desse processo Delphi está resumida na tabela a seguir:

\begin{tabular}{|c|c|c|}
\hline \multirow{2}{*}{ RODADAS } & \multicolumn{2}{|c|}{ Quantidade de questionários } \\
\cline { 2 - 3 } & enviados & respondidos \\
\hline Rodada 1 & 51 & 39 \\
\hline Rodada 2 & 44 & 32 \\
\hline
\end{tabular}

TABEL A 4-1 NÚMERO DE RODADAS E QUANTIDADE DE PARTICIPANTES AO LONGO DESSE PROCESSO DELPHI.

Para iniciar a aplicação da técnica Delphi, foram selecionados 51 profissionais entre projetistas, construtores, administradores, incorporadores, corretores, consultores, analistas, usuários e investidores de edifícios brasileiros de escritórios, os quais constituíram a amostra de PMEBE's empregada neste estudo ou o painel Delphi. No entanto, apenas 39 respostas do primeiro questionário foram obtidas. Ainda assim, o segundo questionário foi enviado para 44 PMEBE's: todos os participantes que responderam o primeiro questionário e aqueles que, apesar de não terem respondido o primeiro questionário, pediram para continuar no processo. Dessa segunda rodada foram obtidas 32 respostas, o que significa que aproximadamente $63 \%$ dos respondentes foram mantidos durante todo o processo Delphi.

O questionário resultante da fase preparatória foi enviado a todos participantes da primeira rodada acompanhado de uma carta esclarecendo os objetivos da pesquisa, a técnica Delphi e o papel dos participantes. Ele pode ser visualizado no ANEXO C Primeiro Questionário do Processo Delphi. 
Esse questionário foi organizado, conforme está detalhado no capítulo "5 MÉTODO UTILIZADO PARA ARBITRAGEM INICIAL DA MATRIZ DE ATRIBUTOS", de forma a permitir que cada participante emitisse seus pareceres sobre cada um dos atributos listados e acrescentasse novos atributos à lista de acordo com sua experiência.

A primeira pergunta, elaborada para cada atributo, era se o mesmo deveria ou não pertencer à matriz de atributos, isto é, se ele era ou não relevante para classificar um edificio de escritórios quanto ao seu desempenho, sob o ponto de vista do usuário. Cada uma dessas respostas, que só podia assumir os valores SIM ou NÃO, era uma variável qualitativa.

Para cada atributo, respondida a primeira pergunta, o PMEBE devia opinar sobre a importância do atributo em questão em relação aos demais atributos a serem analisados. Isto era feito através da atribuição de um fator ou peso para cada atributo (fator de importância relativa). A escala estabelecida para tais respostas era a mesma para todos os atributos: discreta de 0 a 100, o que significa que o fator podia assumir valores inteiros entre 0 e 100 . Os PMEBE's foram orientados que o valor 0 devia ser utilizado apenas para pesar os atributos cuja primeira pergunta tivesse recebido NÃO como resposta, que o valor 100 era o peso máximo possível e que era admitido empate entre diferentes atributos. $\mathrm{O}$ fator de importância relativa de cada atributo constituía uma variável quantitativa.

Caso o participante acrescentasse um ou mais atributos à lista recebida, ele devia opinar sobre sua importância relativa seguindo as mesmas regras.

As respostas do primeiro questionário foram analisadas e tratadas ${ }^{24}$ através do cálculo da frequêencia relativa, no caso das variáveis qualitativas (atributo deveria ou não pertencer à matriz) e da moda e da dispersão em relação à moda, no caso das variáveis quantitativas (fator de importância relativa de cada atributo).

Essas estatísticas constituíram o feedback enviado aos participantes junto com o segundo questionário, cujo cabeçalho e apenas dois atributos estão apresentados a seguir para facilitar a compreensão do processo Delphi e sua aplicação específica nesta pesquisa. 


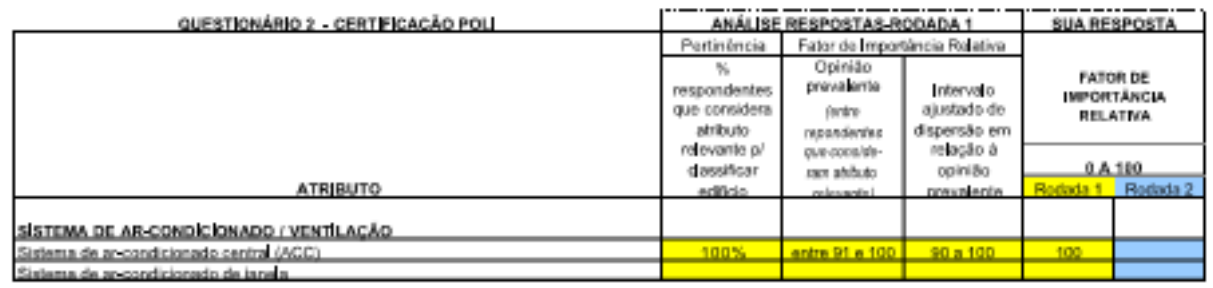

FIGURA 4-1 ESTRUTURA DO SEGUNDO QUESTIONÁRIO DESSE PROCESSO DEL.PHI.

Este segundo questionário sofreu algumas alterações em relação ao primeiro:

[i] - inserção de quatro colunas referentes à primeira rodada do processo Delphi, sendo três delas informativas da análise das respostas daquela rodada (porcentagem de respondentes que havia considerado o atributo relevante para classificar um edifício de escritórios, opinião prevalente entre os respondentes sobre o fator de importância relativa, intervalo ajustado de dispersão em relação a esta opinião prevalente) e a outra coluna, com a resposta particular do participante para o valor do fator de importância relativa na primeira rodada ${ }^{25}$, apenas para efeito comparativo, visando facilitar sua resposta nessa segunda rodada. Nesse sentido, o respondente foi instruido que podia atribuir, para o fator de importância relativa, valor igual ou diferente daquele dado na primeira rodada.

[ii] - eliminação das duas colunas utilizadas na primeira rodada para o respondente opinar sobre a pertinência ou não do atributo no sistema de classificação: nesse segundo questionário, a não pertinência passou a ser expressa pela nota zero do fator de importância relativa, conforme orientado aos participantes.

[iii] - inserção de atributos sugeridos pelos respondentes da primeira rodada: acrescentados nesse segundo questionário sem seu fator de importância relativa resultante da primeira rodada, uma vez que eles foram sugeridos por apenas alguns participantes e, assim, a importância relativa desses atributos julgada por estes respondentes não podia ser considerada como opinião prevalente de mercado. Os 
participantes foram instruídos que deviam atribuir um primeiro valor para o fator de importância relativa desses atributos.

A análise e o tratamento de respostas do segundo questionário foram análogos ao realizado ao término da primeira rodada, encerrando o processo Delphi neste estudo.

Estas últimas respostas tratadas constituíram as opiniões prevalentes no meio especializado sobre quais atributos dos edifícios brasileiros de escritórios deveriam compor a matriz de atributos e qual a importância de cada atributo componente em relação aos demais. Elas foram, entre outros recursos, empregadas para arbitrar inicialmente a matriz de atributos. 
APÊNDICE B - MATRIZ INIIAL DE ATRIBUTOS E CERTIFICADO DE QUALIDADE DE CONDOMÍNIOS LOGÍSTICOS NO BRASIL. 


\begin{tabular}{|c|c|c|c|}
\hline \multirow{2}{*}{ Atributos Associados ao Galpão } & \multicolumn{2}{|c|}{$\begin{array}{c}\text { PERTINÊNCIA DO } \\
\text { ATRIBUTO } \\
\text { NO SISTEM A DE } \\
\text { CLASSIFICAÇÃO } \\
\end{array}$} & \multirow[t]{2}{*}{\begin{tabular}{|c|c}
$\begin{array}{c}\text { FATOR DE } \\
\text { IMPORTÂN } \\
\text { CIA } \\
\text { RELATIVA }\end{array}$ \\
0A 100 \\
\end{tabular}} \\
\hline & SIM & NÃO & \\
\hline \multicolumn{4}{|l|}{ 1. Sistema Elétrico do Galpão } \\
\hline \multicolumn{4}{|l|}{ Disponibilidade de Infraestrutura elétrica na área de Armazenagem } \\
\hline \multicolumn{4}{|l|}{ Medidores individualizados de consumo de energía por módulo. } \\
\hline \multicolumn{4}{|l|}{ Infraestrutura para opção de transformador elétrico independente por módulo } \\
\hline \multicolumn{4}{|l|}{\begin{tabular}{|l|} 
Barramentos blindados para área de escritórios \\
Protecão magnética
\end{tabular}} \\
\hline \multirow{2}{*}{\multicolumn{4}{|c|}{$\begin{array}{l}\text { Proteção magnética } \\
\text { Proteção térmica }\end{array}$}} \\
\hline & \multicolumn{3}{|c|}{ Proteção térmica } \\
\hline \multicolumn{4}{|l|}{ Proteção contra curto-circuito } \\
\hline \multicolumn{4}{|l|}{ Infraestrutura para gerador de energia privativo } \\
\hline \multicolumn{4}{|l|}{ Sistemas de aterramento independentes (elétrico/ eletrônico) } \\
\hline \multicolumn{4}{|l|}{ Suprimento de energia por galpão (W/m² privativo) } \\
\hline Atributos a acrescentar, segundo seu critério: & & & \\
\hline & & & \\
\hline & & & \\
\hline & & & \\
\hline & & & \\
\hline
\end{tabular}




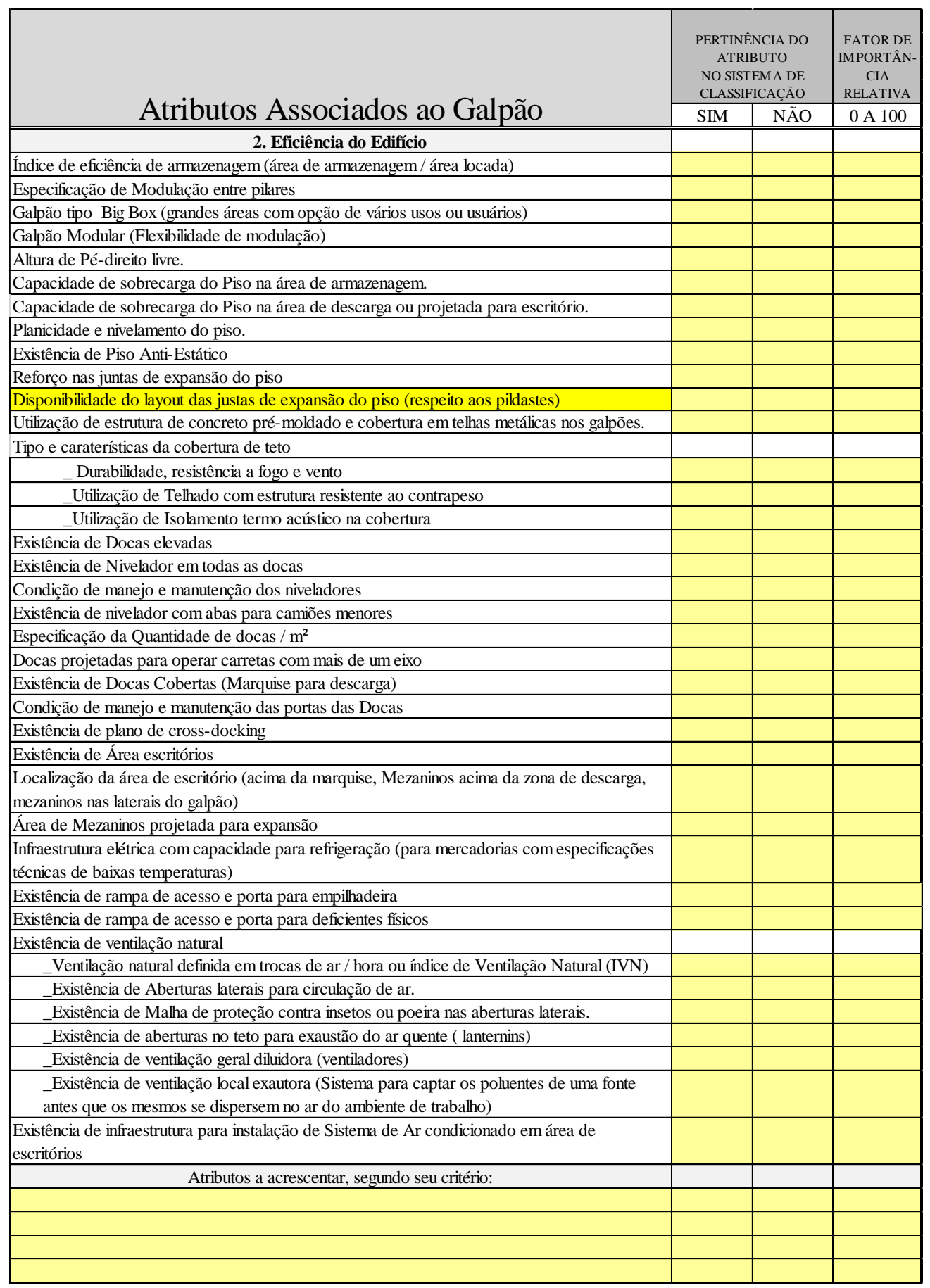




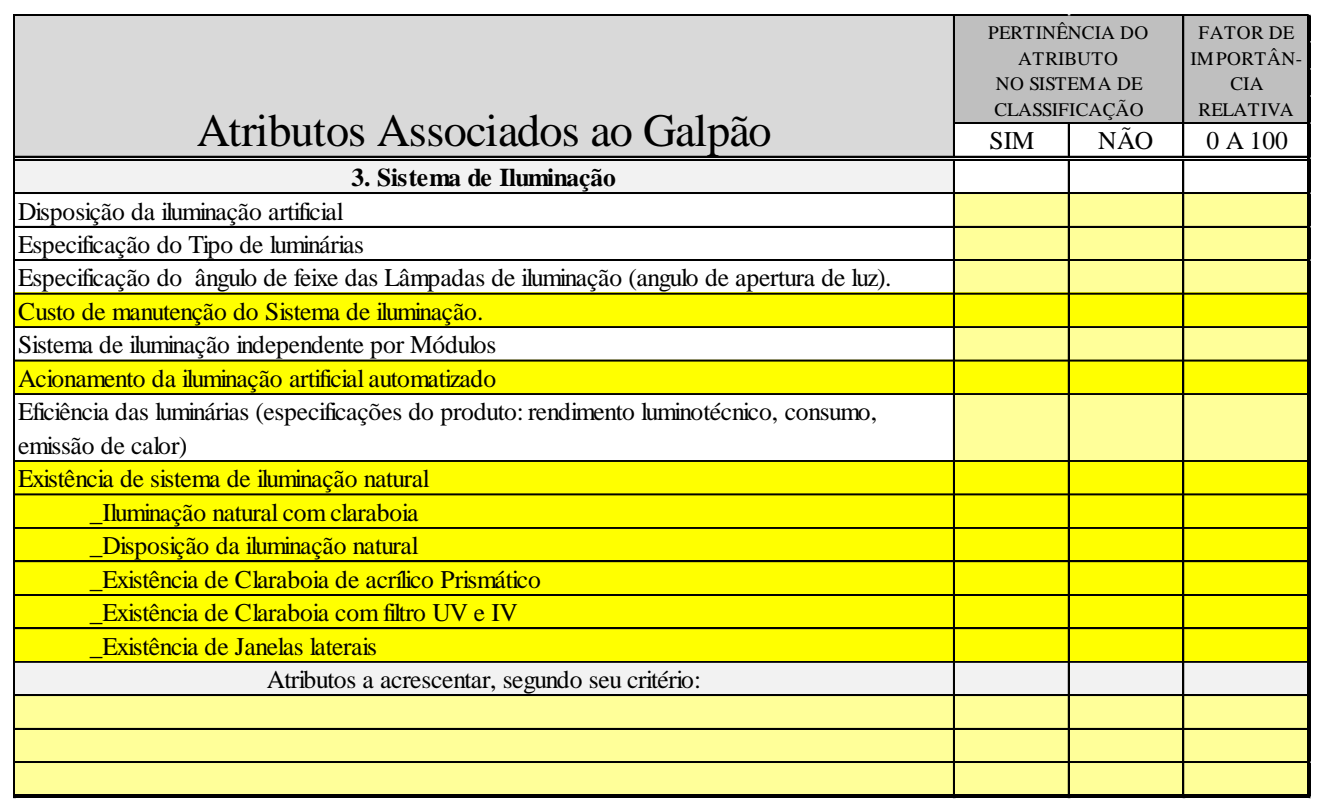

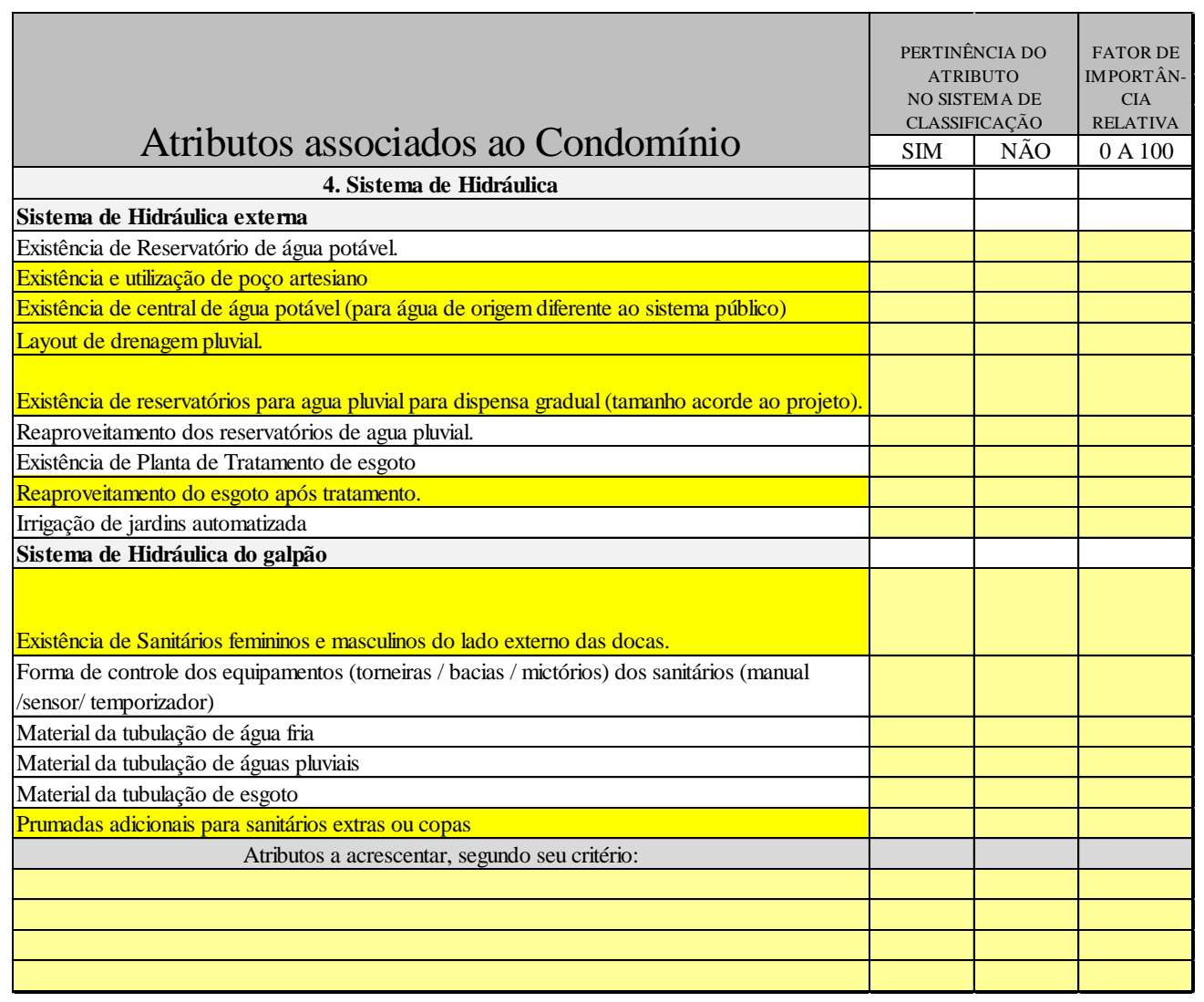




\begin{tabular}{|c|c|c|c|}
\hline \multirow{2}{*}{ Atributos associados ao Condomínio } & \multicolumn{2}{|c|}{$\begin{array}{l}\text { PERTINÊNCIA DO } \\
\text { ATRIBUTO } \\
\text { NO SISTEM A DE } \\
\text { CLASSIFICAÇÃOO }\end{array}$} & \multirow{2}{*}{\begin{tabular}{|c}
$\begin{array}{c}\text { FATOR DE } \\
\text { IMPORTÂN } \\
\text { CIA } \\
\text { RELATIVA }\end{array}$ \\
0 A 100 \\
\end{tabular}} \\
\hline & SIM & NÃO & \\
\hline \multicolumn{4}{|l|}{ 5. Sistema de Detecção e Combate a Incêndio interno e externo } \\
\hline \multicolumn{4}{|l|}{ Sistema de Deteç̧ão e Combate a Incêndio do Galpão } \\
\hline \multicolumn{4}{|l|}{ Existência e disposição de Sprinklers } \\
\hline \multicolumn{4}{|l|}{ Existência de Detectores de calor dentro dos galpões } \\
\hline \multicolumn{4}{|l|}{ Existência de Sensores de fumaça dentro dos galpões } \\
\hline \multicolumn{4}{|l|}{ Existência de Acionamento manual de alarmes. } \\
\hline \multicolumn{4}{|l|}{ Existência de Alarmes visuais e sonoros } \\
\hline \multirow{2}{*}{\multicolumn{4}{|c|}{\begin{tabular}{|l|} 
Existência de Sistema de som de emergência \\
Existência de Iluminacão de emeroência.
\end{tabular}}} \\
\hline & & & \\
\hline \multicolumn{4}{|l|}{ Existência de Sistema de exaustão de emergência nos galpões } \\
\hline \multicolumn{4}{|l|}{ Sistema de Detecção e Combate a Incêndio do Condomínio } \\
\hline \multicolumn{4}{|l|}{ Existência de Hidrantes } \\
\hline \multicolumn{4}{|l|}{ Existência de Extintores } \\
\hline \multicolumn{4}{|l|}{ Existência de Rotas de emergência em caso de incêndio } \\
\hline \multirow{2}{*}{\multicolumn{4}{|c|}{ Existência de Bombas de pressão e recalque ligadas ao gerador }} \\
\hline \multicolumn{2}{|l|}{ Existência de Sistema de telefonia hot-line para comunicação com central de incêndio } & & \\
\hline \multicolumn{4}{|l|}{ Existência de espaço físico para Brigada de incêndio e bombeiro de plantão } \\
\hline Atributos a acrescentar, segundo seu critério: & & & \\
\hline & & & \\
\hline & & & \\
\hline & & & \\
\hline
\end{tabular}

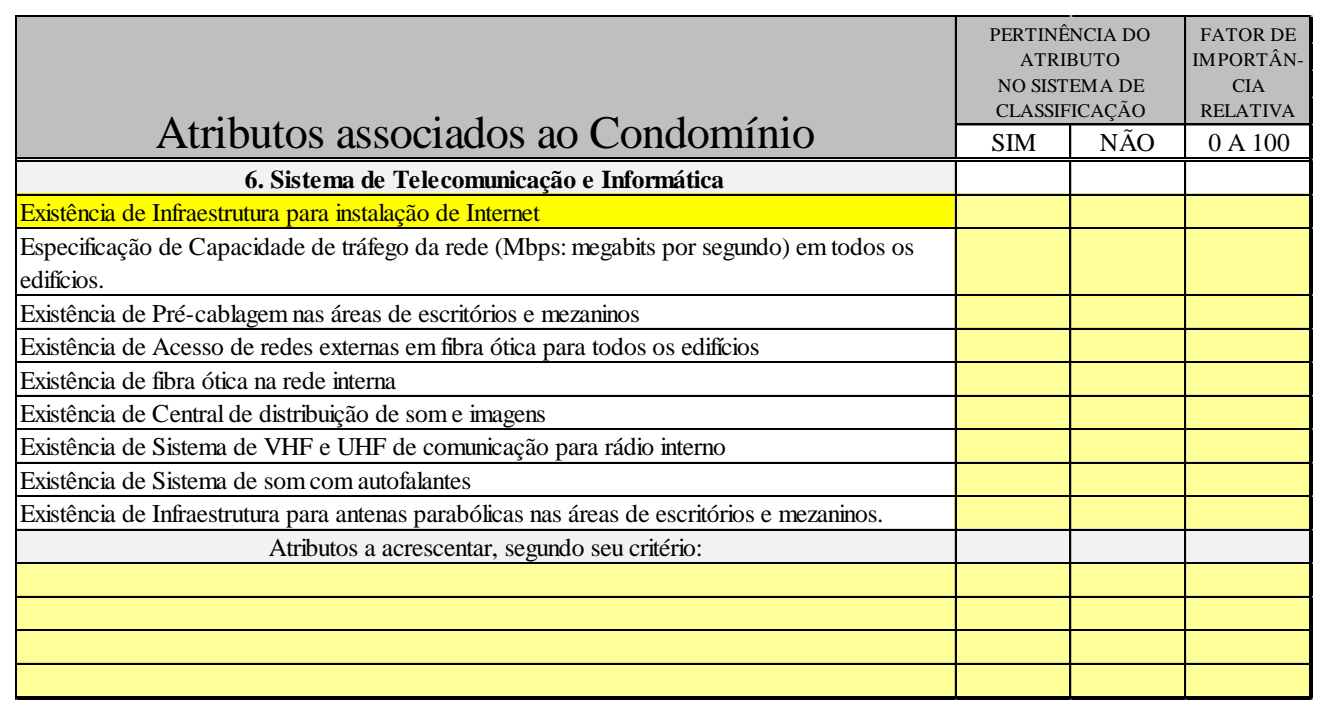




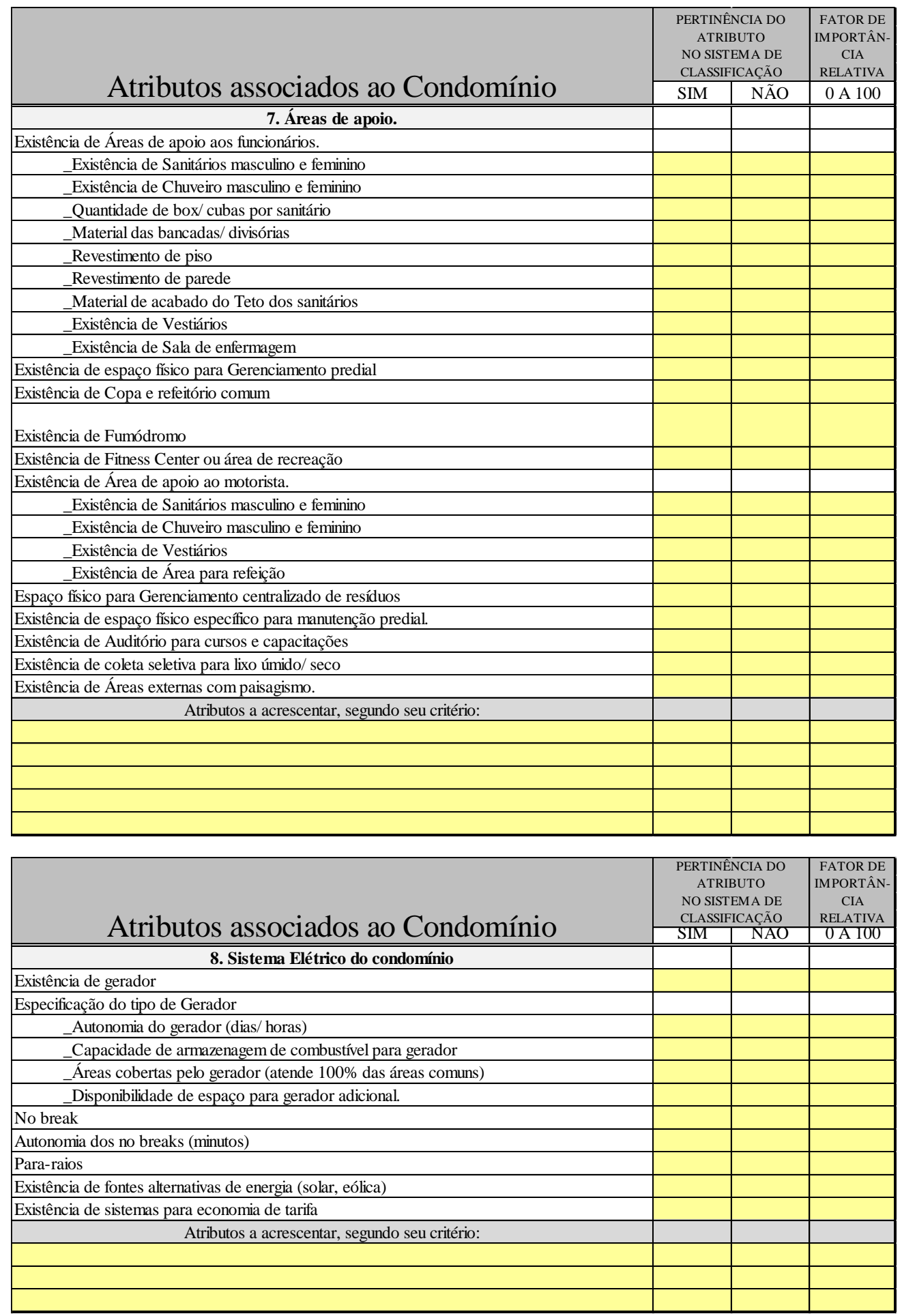




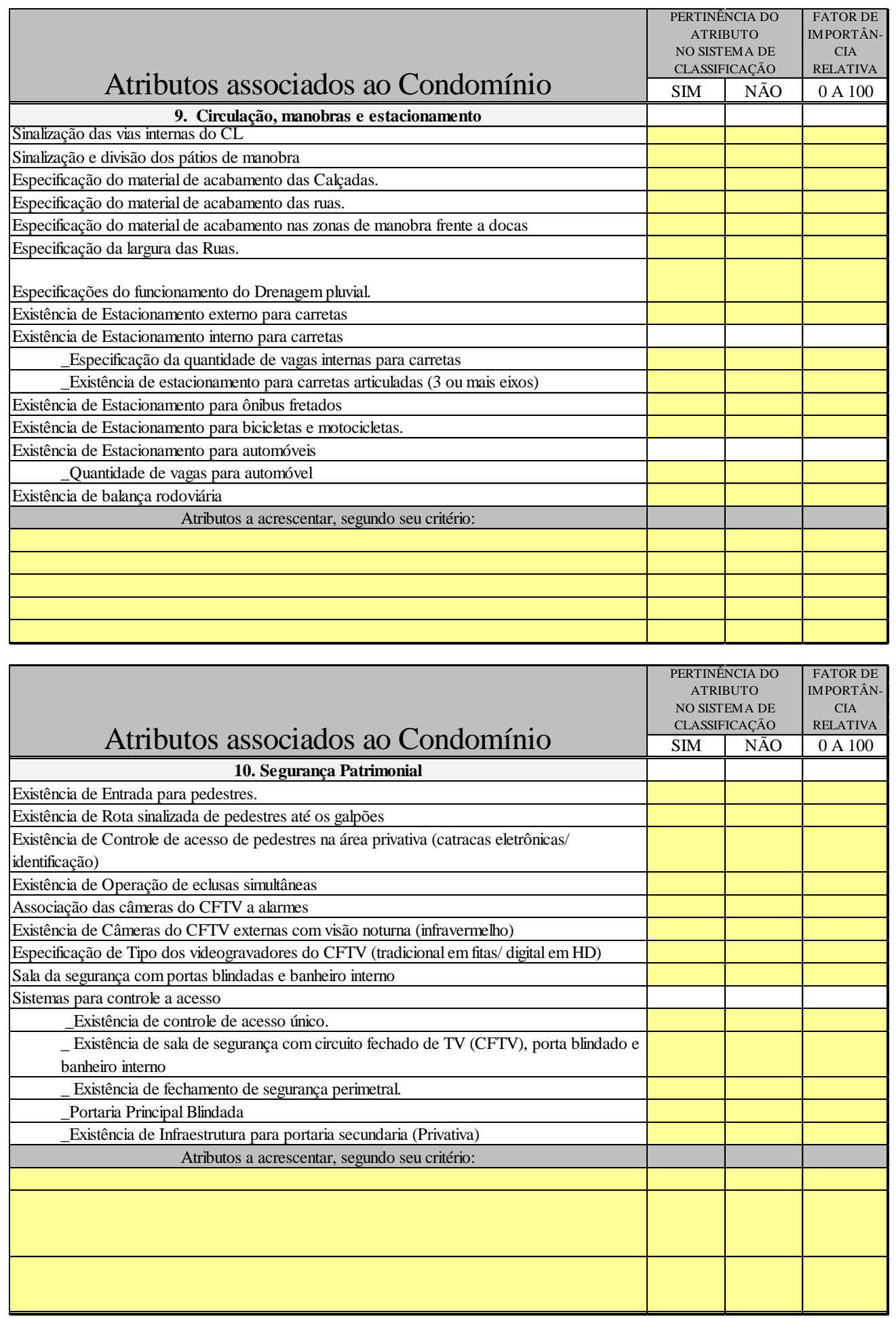




\begin{tabular}{|l|c|c|c|}
\hline \multicolumn{1}{|c|}{ 11. Localização } & \multicolumn{1}{c|}{$\begin{array}{c}\text { PERTINÊNCIA DO } \\
\text { ATRIBUTO } \\
\text { NO SISTEMA DE } \\
\text { CLASSIFICAÇ̃̃o }\end{array}$} & $\begin{array}{c}\text { FATOR DE } \\
\text { IMPORÂN- } \\
\text { CIA } \\
\text { RELATIVA }\end{array}$ \\
\hline & SIM & NÃO & 0 A 100 \\
\hline \hline Visibilidade do projeto desde a rodovia principal de acesso & & & \\
\hline $\begin{array}{l}\text { Especificação de acesso (rota de fácil acesso desde a rodovia principal até a entrada do } \\
\text { projeto). }\end{array}$ & & & \\
\hline Quantidade de pedágios entre o projeto e o principal centro urbano de interesse & & \\
\hline Proximidade com polos industriais & & & \\
\hline Infraestrutura das vias de acesso & & & \\
\hline Localizado em zona de incentivo fiscal & & & \\
\hline Condição de acessibilidade a Portos & & & \\
\hline Condição de acessibilidade a aeroportos & & & \\
\hline Condição de acessibilidade a sistema estratégica para tráfego de mercadorias & & & \\
\hline Atributos a acrescentar, segundo seu critério: & & & \\
\hline & & & \\
\hline & & & \\
\hline
\end{tabular}


APÊNDICA C - ARBITRAGEM DA TÉCNICA DELPHI, VERONEZI (2004) 


\subsection{Arbitragem da matriz de atributos}

Conforme apresentado no capítulo "3 DESCRIÇÃO GERAL DO SISTEMA DE CERTIFICAÇÃO”, a matriz de atributos é constituída pelas seguintes colunas:

"Particularidade", "Atributo", "Fator de importância relativa", "Pontuação para o

edifício" e "Atributo pontuado e ponderado". Estas duas últimas colunas são preenchidas somente por ocasião de avaliação de determinado edifício de escritórios, enquanto as colunas "Particularidade", "Atributo" e "Fator de importância relativa" são fixas independentemente do edifício em análise.

O preenchimento da coluna "Particularidade" com siglas que indicam que determinados atributos da matriz têm sua avaliação restrita a certas características da edificação, enquanto outros têm sua análise vinculada a um ou mais atributos contidos ou não na matriz, foi feito em função de restrições ou vínculos naturais da construção civil, logo após definição da coluna "Atributo".

No entanto, o preenchimento das colunas "Atributo" e "Fator de importância relativa" foi inicialmente arbitrado. Portanto, quando se trata a arbitragem inicial da matriz de atributos é a arbitragem inicial do preenchimento destas duas colunas que está sendo tratada.

A detecção das opiniões prevalentes entre PMEBE's foi o passo inicial para essa arbitragem. Os PMEBE's aqui referidos são identificados pela sua proximidade à questão em estudo, o que envolve indivíduos de diferentes formações, ocupações, treinamentos e experiências. São considerados PMEBE's os grandes projetistas, construtores, administradores, incorporadores, corretores, consultores, analistas, usuários e investidores de tais edifícios, inclusive indivíduos envolvidos na elaboração de sistemas classificatórios particulares de determinadas empresas ${ }^{21}$. Em função das diferenças citadas entre os participantes e da subjetividade relacionada à qualidade de um edifício de escritórios os julgamentos obtidos variavam entre os indivíduos do grupo.

Eles opinaram sobre quais os atributos deveriam compor a matriz e qual a importância de cada atributo componente em relação aos demais. A técnica Delphi ${ }^{22}$ foi empregada para obter as opiniões dos PMEBE's e para reduzir a variação de 
respostas entre estes participantes, visando a máxima convergência possível das mesmas.

Ao término de cada rodada de aplicação da técnica Delphi, as respostas dos PMEBE's foram tratadas empregando-se técnicas da Estatística Descritiva ${ }^{23}$.

As opiniões prevalentes no meio especializado foram identificadas ao final da aplicação desse processo e foram empregadas, entre outros recursos, para arbitrar a matiz de atributos.

Essa etapa da pesquisa foi constituída de três partes. A primeira foi preparatória para a elaboração de uma listagem inicial que serviu de subsídio ao início da aplicação da técnica Delphi. A outra parte foi a aplicação efetiva da técnica Delphi: submissão aos PMEBE's de um conjunto de questionários seqüenciais cuidadosamente elaborados, entremeados com informações resumidas e feedback das opiniões, derivado de análise de respostas anteriores. Por último, arbitrourse a matriz de atributos. 
APÊNDICA D - ARBITRAGEM DA ESCALA DE CLASSIFICAÇÃO, VERONEZI (2004) 
[i] - Classe AAA: qualidade mais alta e quase invulnerável. Excepcional aderência do estado detectado para o conjunto de atributos do edifício aos mais altos padrões de construção vigentes, correspondentes à opinião prevalente de mercado (necessidades e anseios do usuário), segundo modelos e critérios desenvolvidos pelo NRE / POLI/ USP. Decorrido o prazo de validade do certificado, é muito improvável que essa aderência seja adversamente afetada por previsíveis evoluções dos parâmetros empregados no mercado imobiliário em termos de materiais e processos construtivos, desenho arquitetônico, tecnologia disponível no edifício, estruturas organizacionais das empresas e localização dentro da malha urbana, este último parâmetro utilizado apenas na classificação regional.

[ii] - Classe AA: qualidade muito alta e não significativamente vulnerável. Ótima aderência do estado detectado para o conjunto de atributos do edifício aos mais altos padrões de construção vigentes, correspondentes à visão prevalente de mercado (necessidades e anseios do usuário), segundo modelos e critérios desenvolvidos pelo NRE / POLI / USP. Decorrido o prazo de validade do certificado, essa aderência não é significativamente vulnerável a previsíveis evoluções dos parâmetros empregados no mercado imobiliário em termos de materiais e processos construtivos, desenho arquitetônico, tecnologia disponível no edifício, estruturas organizacionais das 
empresas e localização dentro da malha urbana, este último parâmetro utilizado apenas na classificação regional.

[iii] - Classe A: qualidade alta e muito pouco vulnerável. Muito boa aderência do estado detectado para o conjunto de atributos do edifício aos mais altos padrões de construção vigentes, correspondentes à opinião prevalente de mercado (necessidades e anseios do usuário), segundo modelos e critérios desenvolvidos pelo NRE / POLI / USP. No entanto, decorrido o prazo de validade do certificado, essa aderência pode ser mais vulnerável, que a aderência das classes superiores, a previsíveis evoluções dos parâmetros empregados no mercado imobiliário em termos de materiais e processos construtivos, desenho arquitetônico, tecnologia disponível no edifício, estruturas organizacionais das empresas e localização dentro da malha urbana, este último parâmetro utilizado apenas na classificação regional.

[iv] - Classe BBB: qualidade boa e pouco vulnerável. Boa aderência do estado detectado para o conjunto de atributos do edifício aos mais altos padrões de construção vigentes, correspondentes à visão prevalente de mercado (necessidades $\mathrm{e}$ anseios do usuário), segundo modelos e critérios desenvolvidos pelo NRE / POLI / USP. Mas, decorrido o prazo de validade do certificado, essa aderência é mais provavelmente afetada adversamente, que a aderência das classes superiores, a previsíve is evoluções dos parâmetros empregados no mercado imobiliário em termos de materiais e processos construtivos, desenho arquitetônico, tecnologia disponível no edifício, estruturas organizacionais das empresas e localização dentro da malha urbana, este último parâmetro utilizado apenas na classificação regional.

[v] - Classe BB: qualidade regular e vulnerável. Regular aderência do estado detectado para o conjunto de atributos do edifício aos mais altos padrões de construção vigentes, correspondentes à opinião prevalente de mercado (necessidades e anseios do usuário), segundo modelos e critérios desenvolvidos pelo NRE / POLI / USP. Decorrido o prazo de validade do certificado, é provável que essa aderência seja adversamente afetada por previsíveis evoluções dos parâmetros empregados no mercado imobiliário em termos de materiais e processos construtivos, desenho arquitetônico, tecnologia disponível no edifício, estruturas organizacionais 
das empresas e localização dentro da malha urbana, este último parâmetro utilizado apenas na classificação regional.

[vi] - Classe B: qualidade mínima e muito vulnerável. Mínima aderência do estado detectado para o conjunto de atributos do edifício aos mais altos padrões de construção vigentes, correspondentes à visão prevalente de mercado (necessidades $\mathrm{e}$ anseios do usuário), segundo modelos $\mathrm{e}$ critérios desenvolvidos pelo NRE / POLI / USP. Decorrido o prazo de validade do certificado, é muito provável que essa aderência seja adversamente afetada por previsíveis evoluções dos parâmetros empregados no mercado imobiliário em termos de materiais e processos construtivos, desenho arquitetônico, tecnologia disponível no edifício, estruturas organizacionais das empresas e localização dentro da malha urbana, este último parâmetro utilizado apenas na classificação regional.

[vii] - Classe C: qualidade inadequada e altamente vulnerável. Inadequação do estado detectado para o conjunto de atributos do edifício em relação aos mais altos padrões de construção vigentes, correspondentes à opinião prevalente de mercado (necessidades e anseios do usuário), segundo modelos e critérios desenvolvidos pelo NRE / POLI / USP. Decorrido o prazo de validade do certificado, é altamente provável que essa inadequação seja adversamente afetada por previsíveis evoluções dos parâmetros empregados no mercado imobiliário em termos de materiais e processos construtivos, desenho arquitetônico, tecnologia disponível no edifício, estruturas organizacionais das empresas e localização dentro da malha urbana, este último parâmetro utilizado apenas na classificação regional. Após esse prazo, é altamente provável que o edifício passe a ter qualidade desprezivel e não mais se enquadre nesta escala de classificação. 
APÊNDICA E - COMITÊ DE CLASSIFICAÇÃO, VERONEZI (2004) 


\subsubsection{Comitê de classificação}

O comitê de classificação é composto por cinco professores e pesquisadores do Núcleo de Real Estate da Escola Politécnica da USP. A cada análise de edifício de escritórios um membro do comitê de classificação é nomeado seu relator, estando todos os membros do comitê aptos a exercer tal função. $\mathrm{O}$ relator é o membro do comitê que deve visitar o edifício a ser certificado e elaborar relatório, opinando sobre a condição detectada para os atributos considerados na matriz de atributos no caso do edifício em análise.

Um membro do comitê de classificação exerce função de coordenador. Ele é indicado pelo coordenador geral do Núcleo de Real Estate da Escola Politécnica da USP. O coordenador do comitê nomeia o relator da análise de edificação a ser realizada. O coordenador do comitê, em casos de excepcionalidade, tem o direito discricionário de anular integralmente o relatório de certo relator e nomear novo relator para reiniciar o processo de classificação.

O comitê de classificação reúne-se para confrontar as classificações sugeridas por cada um de seus membros para o prédio em análise e, então, emitir parecer sobre a inserção do edifício em questão no sistema de classificação segundo certa categoria. Para cada prédio são emitidos dois pareceres, sendo um referente à classificação regional e o outro referente à classificação nacional. A diferenciação entre as duas classificações é feita através da extensão "Br" aplicada à classificação nacional.

Detalhando o que foi introduzido no início deste capítulo, esse comitê é necessário para fornecer credibilidade ao sistema de classificação, uma vez que ele garante que a classificação hierarquizada do edifício (categoria) represente a opinião da instituição emissora do certificado (NRE / POLI / USP) e não a opinião do indivíduo que analisa o edifício (relator e membro do comitê). Nesse sentido, foi definido nesta pesquisa um processo de classificação, que deve ser rigorosamente seguido. Ele inclui regras estabelecidas para conduzir a tomada de decisão pelo comitê de classificação. O processo de classificação, bem como o REGIMENTO PARA AS DECISÕES DO COMITÊ DE CLASSIFICAÇÃO, estão apresentados no próximo subitem deste texto. 
APÊNDICA F - ARTIGOS, VERONEZI (2004) 
Art. $1^{\circ}$. - O relator defende, perante os demais membros do comitê de classificação, o posicionamento por ele assumido quanto a pontuação dos atributos do edifício visitado e conseqüentes classificações (nacional e regional) para o mesmo.

Art. $2^{0}$. - Baseando-se na defesa feita pelo relator de seu relatório, os demais membros do comitê podem discordar das pontuações conferidas pelo relator aos atributos do edifício. Cada membro do comitê altera aquelas pontuações de atributos por ele criticadas, sempre seguindo os critérios estabelecidos para preenchimento da matriz de atributos, e sugere em qual categoria regional e em qual categoria nacional inserir o edifício (em função do enquadramento, nas escalas de classificação regional e nacional, da pontuação final do prédio resultante de sua pontuação para os atributos do mesmo).

Art. $3^{0}$. - As opiniões do relator e dos outros quatro membros do comitê de classificação a respeito das classes, regional e nacional, nas quais inserir o edifício de escritórios devem ser confrontadas. Isto exposto, para cada tipo de classificação (regional e nacional) tem-se:

3.1. - a classe que receber três ou mais votos, incluindo ou não o voto do relator, é aquela na qual o edifício em análise será inserido para emissão do certificado de sua qualidade;

3.2. - caso ocorra total dispersão dos votos, isto é, não coincida o número mínimo de três votos, uma das seguintes alternativas será adotada pelo comitê: 
3.2.1. - excepcionalidade / reinício do processo de classificação: caso ocorra total discordância dos votos e o coordenador do comitê entenda que há grandes dúvidas a respeito da classe na qual o prédio em análise deve ser inserido, para garantir a justeza da classificação, o coordenador encerra a primeira análise sem emissão de parecer sobre a classificação do edifício e reinicia o processo de classificação, nomeando outro relator, diferente do primeiro.

3.2.2 - prevalecimento da opinião do relator: caso ocorra total discordância dos votos, mas o coordenador do comitê entenda que não há grandes dúvidas a respeito da classe na qual o prédio em análise deve ser inserido, prevalece a sugestão de classificação do relator. Isto porque, não havendo grandes dúvidas quanto à classificação do edifício, os votos dispersos entre as categorias acima daquela sugerida pelo relator podem ser concentrados na categoria imediatamente superior a esta última. Analogamente, os votos dispersos entre as categorias abaixo daquela sugerida pelo relator podem ser concentrados na categoria imediatamente inferior a esta última. Assim, após esse eventual ${ }^{19}$ rearranjo dos votos para as categorias imediatamente acima ou abaixo da sugerida pelo relator, as seguintes combinações de votos são possíveis:

\begin{tabular}{|c|c|c|c|}
\hline \multirow{2}{*}{$\begin{array}{c}\text { CATEGORIA } \\
\text { imediatamente } \\
\text { acima * }^{*} \\
\end{array}$} & \multicolumn{3}{|c|}{$\begin{array}{l}\text { QUANTIDADE DE VOTOS } \\
\text { (após eventual rearranio) }\end{array}$} \\
\hline & 2 & 2 & 1 \\
\hline $\begin{array}{l}\text { sugerida } \\
\text { pelo relator }\end{array}$ & 1 & 2 & 2 \\
\hline $\begin{array}{c}\text { imediatamente } \\
\text { abaixo * }\end{array}$ & 2 & 1 & 2 \\
\hline COMBINAÇÃO & A & B & C \\
\hline
\end{tabular}

TABELA 3-1 COMBINAÇÕES POSSÍVEIS DE VOTOS SUGERIDOS PELOS MEMBROS DO COMTÊ DE CLASSSIFICAÇÃo 
COMBINAÇÃO A: a votação está empatada entre as categorias imediatamente acima e abaixo daquela sugerida pelo relator. Como a opinião do relator representa a posição intermediária, ela é adotada para classificação do edifício.

COMBINAÇÃO B: a votação está empatada entre a categoria sugerida pelo relator e a categoria imediatamente acima desta. $\mathrm{O}$ voto singular deve ser usado para desempate, devendo ser considerado como voto adicional para a categoria mais próxima a ele. A categoria mais próxima ao voto singular é a sugerida pelo relator, que, então, passa a superar em votação a categoria imediatamente acima dela. Assim, a opinião do relator é adotada para classificação do edifício.

COMBINAÇÃO C: a votação está empatada entre a classe sugerida pelo relator e a classe imediatamente abaixo desta. $\mathrm{O}$ voto singular deve ser usado para desempate, devendo ser considerado como voto adicional para a categoria mais próxima a ele. A categoria mais próxima ao voto singular é a sugerida pelo relator, que, então, passa a superar em votação a categoria imediatamente abaixo dela. Assim, a opinião do relator é adotada para classificação do edifício.

Dessa forma, esse regimento abrange todas combinações possíveis de votação pelos membros do comitê de classificação e conduz a emissão dos pareceres finais a respeito das categorias, regional e nacional, nas quais inserir o edifício de escritórios.

Art. 4. - Elaboração da ata de reunião do comitê de classificação com os pareceres finais sobre as classificações nacional e regional do prédio analisado. Estes pareceres finais a serem emitidos pelo comitê podem se dar após uma única análise do edifício ou o coordenador do comitê pode solicitar nova análise do prédio por um outro relator para, então, se dar a emissão dos pareceres. 